University of Pennsylvania Carey Law School

Penn Law: Legal Scholarship Repository

Faculty Scholarship at Penn Law

7-2014

\title{
Good Enough for Government Work: Two Cheers for Content Neutrality
}

Seth F. Kreimer

University of Pennsylvania Carey Law School

Follow this and additional works at: https://scholarship.law.upenn.edu/faculty_scholarship

Part of the American Politics Commons, Applied Behavior Analysis Commons, Constitutional Law Commons, First Amendment Commons, Public Law and Legal Theory Commons, and the Public Policy Commons

\section{Repository Citation}

Kreimer, Seth F., "Good Enough for Government Work: Two Cheers for Content Neutrality" (2014). Faculty Scholarship at Penn Law. 492.

https://scholarship.law.upenn.edu/faculty_scholarship/492

This Article is brought to you for free and open access by Penn Law: Legal Scholarship Repository. It has been accepted for inclusion in Faculty Scholarship at Penn Law by an authorized administrator of Penn Law: Legal Scholarship Repository. For more information, please contact PennlawIR@law.upenn.edu. 


\title{
GOOD ENOUGH FOR GOVERNMENT WORK: TWO CHEERS FOR CONTENT NEUTRALITY
}

\author{
Seth F. Kreimer*
}

\begin{abstract}
When then-Professor Elena Kagan emerged on the public stage in the mid-1990s, she declared "the distinction between content-based and content-neutral regulations of speech serves as the keystone of First Amendment law." In the last decade and a half, commentators and Supreme Court opinions regularly echoed that declaration. Yet the First Amendment does not mention "content neutrality." The phrase is an artifact of modern constitutional doctrine-a doctrine subjected to a sustained barrage of judicial and academic criticism.
\end{abstract}

Most scholarly critiques of content neutrality focus on First Amendment theory and Supreme Court opinions. After surveying these critiques, along with the incomplete defenses of content neutrality, this Article seeks illumination by shifting to a more grounded focus. I compare the 713 reported cases in which the lower federal courts deployed the doctrine between September 2009 and August 2013 with the First Amendment cases decided by the Roberts Court. I analyze what political science and behavioral decision theory tell us about the way that the content neutrality doctrine is likely to function in setting the terms of interaction between the private actors and government officials who actually populate and seek guidance from the case law.

Unlike the recent Supreme Court docket, contemporary content neutrality cases in the lower courts center on contests between potential "village tyrants"-local officials and street level bureaucrats who will often find it difficult to hold fast to tolerant ideals- and local dissenters who are likely to provoke them. In these struggles, there are important reasons to prefer a strong doctrine of content neutrality to its proposed doctrinal competitors. Content neutrality is important not as a first best rule to assure that the Supreme Court properly implements a theory of the First Amendment, but as a usable norm for the government actors who make decisions before court proceedings commence and for the polity to which those actors answer.

Content neutrality frames the terms of engagement between the governed and the governors of the United States in ways that incline the "general spirit of the people and of the government" to the protection of rights of free expression. Its flamboyant protection of speech repugnant to a variety of constituencies means that the lived reality of free expression will mobilize support from an array of political factions. Content neutrality is, as the Court maintained in laying the doctrine's foundations, an important practical element of constitutional architecture that preserves a "profound national commitment to the principle that debate on public issues should be uninhibited, robust, and wide-open."

* Kenneth W. Gemmill Professor of Law, University of Pennsylvania Law School

$\dagger \quad$ This work has benefitted from the valuable research assistance of Cory Brader and Shriram Harid, the comments of Tess Wilkinson-Ryan and Sandy Mayson, and the enormous insight, skill, and technical assistance of research librarian Mariah Ford, who made the statistical analysis possible. Each is entitled to great thanks and credit for the virtues of this piece. Responsibility for errors and lapses remains my own. 


\section{TABLE OF CONTENTS}

ABSTRACT

INTRODUCTION: A "KEYSTONE OF FIRST AMENDMENT LAW" ....1263

I. Content Neutrality AND ITS Discontents ......................1265

A. The Prevalence of Content Neutrality Doctrine ................. 1265

B. Critiques of Content Neutrality ...................................... 1266

C. Incomplete Defenses ................................................. 1271

D. Good Enough for Government Work: Content Neutrality as Norm and Heuristic .............................................. 1276

II. A CENSUS OF CONTENT NEUTRALITY IN ACTION ...................1277

A. Village Tyrants................................................... 1279

B. Village Hampdens................................................ 1282

1. The Prevalence of Village Hampdens........................1282

2. The Hampdens' Champions..................................1287

C. Content Neutrality, the Public Forum, and Its Patrons ....... 1289

1. Against The Doctrine: Content Neutral Wins, Content Based Losses....................................................1289

2. Public Forum, Limited Public Forum, Direct Regulation 1292

3. Weak and Strong Content Neutrality.......................1296

4. The Venues and Patrons of Content Neutrality ...........1298

III. “THE SPIRIT OF GOVERNMENT": ROBUST FREE SPEECH IN A DECENTRALIZED FEDERAL SYSTEM........................................1301

A. Perspectives on Getting It Right .................................... 1303

1. The View from the Supreme Court ...........................1303

2. The View from the Lower Courts and the Firing Line ...1304

B. The Politics and Heuristics of Village Tolerance and Tyranny............................................................ 1305

1. Why We Cannot Trust Proportionality Inquiries to Induce Potential Village Tyrants to Properly Protect Free Expression .................................................1305

2. Why a Focus on Viewpoint Neutrality and Motivation Is Inadequate to Motivate and Discipline Potential Village Tyrants................................................ 1314

C. Content Neutrality, Heuristics, and Avoiding Village

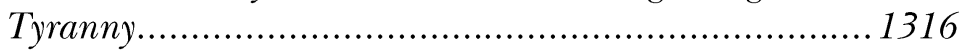

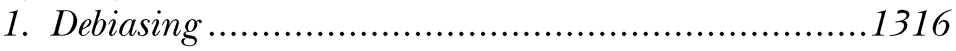


2. Bright Lines, Motivated Cognition, and Learning ......1319

3. Protective Politics ................................................. 1322

4. Robustness and Stability......................................1324

IV. "The SPirit OF the PeOPle": Constitutional Culture IN THE LAND OF THE FREE AND THE HOME OF THE BRAVE . 1328

A. The Importance of Vivid Commitment to Free Expression .... 1330

B. The Public Meaning of Toleration in a Diverse Democracy and the Demand for Censorship

C. The Land of the Free and the Home of the Brave............... 1337

CONCLUSION: Two CHEERS FOR CONTENT NEUTRALITY. 1342

APPENDIX I: ROBERTS COURT OPINIONS REFERRING TO CONTENT NEUTRALITY DOCTRINE 1345

APPENDIX II: ROBERTS COURT FIRST AMENDMENT CASES NOT REFERRING TO CONTENT NEUTRALITY ..............................1346

APPENDIX III: METHODOLOGY...............................................1346

\section{INTRODUCTION: A "KeYSTONE OF FIRST AMENDMENT LAW"}

When then-Professor Elena Kagan emerged on the public stage in the mid-1990s, she declared, "The distinction between content-based and content-neutral regulations of speech serves as the keystone of First Amendment law." In the last decade and a half, commentators and Supreme Court opinions regularly echoed that declaration. ${ }^{2}$

1 Elena Kagan, Private Speech, Public Purpose: The Role of Governmental Motive in First Amendment Doctrine, 63 U. CHI. L Rev. 413, 443 (1996) [hereinafter Kagan, Private Speech, Public Purpose] ; see Elena Kagan, Regulation of Hate Speech and Pornography After R.A.V., 60 U. CHI. L. Rev. 873 (1993) [hereinafter Kagan, Regulation of Hate Speech and Pornography After R.A.V.].

2 E.g., Robert C. Post, Democracy, Expertise, and Academic Freedom: A First AMENDMENT JURISPRUDENCE FOR THE MODERN STATE 9 (2012) ("the cornerstone of the Supreme Court's First Amendment jurisprudence"); Joseph Blocher, Viewpoint Neutrality and Government Speech, 52 B.C. L. REv. 695, 706 (2011) ("fundamental to free speech"); Erwin Chemerinsky, Content Neutrality as a Central Problem of Freedom of Speech: Problems in the Supreme Court's Application, 74 S. CAL. L. Rev. 49, 50 (2000) ; Richard H. Fallon, Jr., Judicially Manageable Standards and Constitutional Meaning, 119 HARV. L. REV. 1274, 1304-05 (2006) ("the centerpiece of modern First Amendment doctrine"); Leslie Kendrick, Content Discrimination Revisited, 98 U. VA. L REv. 231, 232 (2012) ("a touchstone of First Amendment law"); Frederick Schauer, Towards an Institutional First Amendment, 89 MiNN. 
Yet the First Amendment does not mention "content neutrality." The constitutional text foregrounds the question of whether a government burden on communication "abridges" "freedom of speech;" it makes no reference to whether the burden is "content based" or "content neutral." The demand for content neutrality is an artifact of modern constitutional doctrine-and that doctrine has been the subject of a sustained barrage of judicial and academic criticism.

Most scholarly critiques of content neutrality focus on First Amendment theory and Supreme Court opinions. After surveying these critiques, along with the incomplete defenses of content neutrality, this Article seeks illumination by shifting to a more grounded focus. I compare the 713 reported cases in which the lower federal courts deployed the doctrine between September 2009 and August 2013 with the First Amendment cases decided by the Roberts Court. I then analyze what political science and behavioral decision theory tell us about the way that the content neutrality doctrine is likely to function in setting the terms of interaction between the private actors and government officials who actually populate and seek guidance from the case law.

Unlike the recent Supreme Court docket, contemporary content neutrality cases in the lower courts center on contests between what Justice Robert Jackson referred to as "village tyrants"3-local officials and street level bureaucrats who often find it difficult to hold fast to tolerant ideals-and local dissenters who are likely to provoke them. In these struggles, there are important reasons to prefer a strong doctrine of content neutrality to its proposed doctrinal competitors.

Content neutrality-unlike competing doctrines of "viewpoint neutrality" or "proportionality"-frames the terms of engagement between the governed and the governors of the United States in ways that incline the "general spirit of the people and of the government" to the protection of rights of free expression. A strong requirement of content neutrality detaches local decision making from conditions most likely to generate intolerant suppression of speech. The doctrine's rigor constructs a chain of vivid public commitments to tolerance; flamboyant protection of speech repugnant to a variety of con-

L. Rev. 1256, 1270 (2005) ("the unalterable core of the First Amendment"). See infra notes 8-9 for Supreme Court opinions featuring this declaration.

3 W. Va. State Bd. of Educ. v. Barnette, 319 U.S. 624, 638 (1943) ("There are village tyrants as well as village Hampdens, but none who acts under color of law is beyond reach of the Constitution.").

4 The Federalist No. 84, at 535 (Alexander Hamilton) (Benjamin Fletcher Wright ed., 1961). 
stituencies means that the lived reality of free expression can mobilize support from an array of political factions. Content neutrality is thus important as a usable norm for the government actors who make decisions before court proceedings commence and for the polity to which those actors answer. It is, as the Court maintained in laying the doctrine's foundations, a practical element of the constitutional architecture that preserves a "profound national commitment to the principle that debate on public issues should be uninhibited, robust, and wide-open."

\section{Content Neutrality And Its Discontents}

\section{A. The Prevalence of Content Neutrality Doctrine}

References to "content neutrality," "content discrimination," and their cognates were uncommon in academic commentary before the 1970 s. $^{6}$ They emerged in Supreme Court opinions in the same period, ${ }^{7}$ and remain central in current case law. The Roberts Court has

5 Police Dep't of City of Chicago v. Mosley, 408 U.S. 92, 96 (1972) (quoting N.Y. Times Co. v. Sullivan, 376 U.S. 254, 270 (1964)).

6 Harry Kalven's generative analysis, Harry Kalven, Jr., The Concept of the Public Forum: Cox v. Louisiana, 1965 SUP. CT. REv. 1, 23 (1965), marks the earliest invocation in the legal academy of what he refers to as the "classic distinction ... between regulations like Robert's Rules of Order and regulation of content."

Legal scholars of content neutrality began to blossom in the mid-1970s. See, e.g., LAWRENCE H. Tribe, American CONSTITUTIONAL LAW 580-94 (1978); John Hart Ely, Flag Desecration: A Case Study in the Roles of Categorization and Balancing in First Amendment Analysis, 88 HARV. L. REv. 1482, 1486-502 (1975); Kenneth L. Karst, Equality as a Central Principle in the First Amendment, 43 U. CHI. L. REV. 20, 29, 35-43 (1975); Paul B. Stephan III, The First Amendment and Content Discrimination, 68 VA. L. Rev. 203 (1982); Geoffrey R. Stone, Content Regulation and the First Amendment, 25 WM. \& MARY L. REv. 189 (1983) [hereinafter Stone, Content Regulation and the First Amendment]; Geoffrey R. Stone, Fora Americana: Speech in Public Places, 1974 SuP. CT. REv. 233 (1974); Geoffrey R. Stone, Restrictions of Speech Because of its Content: The Peculiar Case of Subject-Matter Restrictions, 46 U. CHI. L. REv. 81, passim (1978).

7 The first opinion to anoint as central the proposition that content discrimination is constitutionally anathema was Justice Marshall's in Mosley, 408 U.S. 92. Mosley cited Harry Kalven's article. Id. at 95 n.3. The opinion invoked the Equal Protection Clause, but relied on both equal protection and First Amendment precedent disapproving of the discriminatory denial of opportunities for speech that stretches back through the 1950s. See $i d$. at 97-100. See, e.g., Shuttlesworth v. Birmingham, 394 U.S. 147 (1969); Cox v. Louisiana, 379 U.S. 536 (1965); Fowler v. Rhode Island, 345 U.S. 67 (1953); Niemotko v. Maryland, 340 U.S. 268 (1951); id. at 282 (Frankfurter, J., concurring in result); Saia v. New York, 334 U.S. 558 (1948).

The rule crafted by the Court in United States v. O'Brien, 391 U.S. 367, 377 (1968), that efforts to regulate expressive conduct must be justified by an interest "unrelated to the suppression of free expression" taps into similar roots, as does the Court's argument in Cohen v. California, 403 U.S. 15, 25 (1971), that "it is largely because governmental offi- 
adverted to content neutrality as a defining element of First Amendment doctrine in no less than twenty-two of the thirty-seven free expression cases it has decided on the merits over the last eight years, and virtually all of the decisions of recognized public consequence. ${ }^{8}$ Majority opinions regularly declaim that "content-based" restrictions on speech are presumptively unconstitutional. ${ }^{9}$

In the lower courts, "content neutrality" is less dominant, but still frames a sizeable percentage of First Amendment case law. Over a four year period from September 2009 to August 2013, 233 court of appeals cases-between $22 \%$ and $34 \%$ of non-pro se free expression cases reported-deployed the content neutrality framework. So did 480 similar cases in the district courts, comprising between $12 \%$ and $18 \%$ of the non-pro se First Amendment cases reported. ${ }^{10}$

\section{B. Critiques of Content Neutrality}

Critics on the Court and in the academy beset "content neutrality" from its inception. Shortly after the doctrine emerged, Justice John

cials cannot make principled distinctions in this area that the Constitution leaves matters of taste and style so largely to the individual."

8 Appendix I identifies the twenty-two cases that deploy the "content neutrality" apparatus. Appendix II sets forth the fifteen cases that do not. Of the cases in Appendix II, seven involve campaign and election law claims addressed under analyses specific to that area of law, and four involve the distinctive doctrine that regulates the rights of public employees.

9 See, e.g., United States v. Alvarez, 132 S. Ct. 2537, 2543 (2012) (Kennedy, J.) (“[A]s a general matter, the First Amendment means that government has no power to restrict expression because of its message, its ideas, its subject matter, or its content." (quoting Ashcroft v. ACLU, 535 U.S. 564, 573 (2002))); Ariz. Free Enter. Club's Freedom Club PAC v. Bennett, 131 S. Ct. 2806, 2820 (2011) (Roberts, C.J.) (“[T] he fundamental rule of protection under the First Amendment [is] that a speaker has the autonomy to choose the content of his own message." (quoting Hurley v. Irish-Am. Gay, Lesbian \& Bisexual Grp. of Bos., 515 U.S. 557, 573 (1995))); Brown v. Entm't Merchs. Ass'n, 131 S. Ct. 2729, 2733 (2011) (Scalia, J.) ("The most basic of those principles" (quoting Ashcroft v. ACLU, 535 U.S. at 573)); United States v. Stevens, 559 U.S. 460, 468 (2010) (Roberts, C.J.) ("'From 1791 to the present,' however, the First Amendment has 'permitted restrictions upon the content of speech in a few limited areas,' and has never 'include[d] a freedom to disregard these traditional limitations." (quoting R.A.V. v. St. Paul, 505 U.S. 377, 382-83 (1992))); Citizens United v. FEC, 558 U.S. 310, 340 (2010) (Kennedy, J.) ("Premised on mistrust of governmental power, the First Amendment stands against attempts to disfavor certain subjects or viewpoints ... [and] restrictions distinguishing among different speakers, allowing speech by some but not others." (internal citations omitted)).

10 The basis for these estimates is set forth in Appendix III. The range depends on the treatment of the $36 \%$ of free expression cases in the lower courts that involve speech by public employees. These cases present unique concerns and deploy a framework in which "content neutrality" is not central. Modern doctrine addressing First Amendment rights of public employees stretches from Pickering $v$. Bd. of Educ., 391 U.S. 563 (1968) to Borough of Duryea, Pa. v. Guarnieri, 131 S. Ct. 2488 (2011). 
Paul Stevens' plurality in Young v. American Mini Theaters, Inc. ${ }^{11}$ argued that "this Court's actual adjudications in the First Amendment area [undercut] .... the stated principle that there may be no restriction whatever on expressive activity because of its content."12 More recent articulations of the framework have acknowledged counterexamples, while attempting to quarantine the exceptions in a closed set of categories. The current account of the doctrine adds the caveat that "content-based restrictions on speech have been permitted, as a general matter, only when confined to the few 'historic and traditional categories [of expression] long familiar to the bar.'"13

Justice Stevens remained critical of the framework throughout his tenure on the Court, maintaining that the First Amendment requires only that government not burden communication on the basis of hostility toward particular viewpoints. ${ }^{14}$ For Justice Stevens, content neutrality was neither a First Amendment mandate ${ }^{15}$ nor an inoculation against searching judicial scrutiny of regulations that adversely impacted speech. ${ }^{16}$

11427 U.S. 50, 65-66 (1976).

12 See id. at 65-67 (citing incitement, fighting words, imminent danger to troops, libel, obscenity, and commercial speech).

13 Alvarez, 132 S. Ct. at 2544 (internal citations omitted).

14 Young, 427 U.S. at 67 (regulation "may not be affected by sympathy or hostility for the point of view being expressed").

15 See, e.g., R.A.V. v. St. Paul, 505 U.S. 377, 420 (1992) (Stevens, J., concurring); FCC v. League of Women Voters, 468 U.S. 364, 408 (1984) (Stevens, J., dissenting); Members of the City Council v. Taxpayers for Vincent, 466 U.S. 789, 804 (1984); Regan v. Time, Inc., 468 U.S. 641, 692 (1984) (Stevens, J., concurring); Widmar v. Vincent, 454 U.S. 263, 277 (1981) (Stevens, J., concurring); Consol. Edison Co. v. Public Serv. Comm'n, 447 U.S. 530, 544-545 (1980) (Stevens, J., concurring) ("Any student of history who has been reprimanded for talking about the World Series during a class discussion of the First Amendment knows that it is incorrect..."(internal citation omitted)); FCC v. Pacifica Found., 438 U.S. 726, 744 (1978).

Justice Stevens' somewhat perplexing opinion in Hill v. Colorado, 530 U.S. 703-04 (2000), characterizing the prohibition of proximate "oral protest" in the vicinity of health care providers as "content neutral," is perhaps best explained as an application of his belief that hostility to particular viewpoints rather than discrimination should invoke a demand for extraordinary justification.

16 Justice Stevens regularly authored opinions invalidating regulations without determining that the regulations were "content based." In these opinions, Stevens invoked contextual analysis of the place of the regulations in the system of free expression. See, e.g., Watchtower Bible \& Tract Soc'y of N.Y., Inc. v. Vill. of Stratton, 536 U.S. 150, 175-80 (2002) (invalidating requirement of registration by door to door solicitors); Bartnicki v. Vopper, 532 U.S. 514, 526-35 (2001) (barring application of a "content-neutral" statute prohibiting distribution of information obtained by illegal wiretaps); United States v. Nat'l Treasury Emps. Union, 513 U.S. 454, 457 (1995) (invalidating a statute that "broadly prohibit[ed] federal employees from accepting any compensation for making speeches or writing articles"); City of Ladue v. Gilleo, 512 U.S. 43, 58-59 (1994) (invalidating prohibition of signs on private property); $c f$. McIntyre v. Ohio Elections Comm'n, 514 U.S. 334, 
On another front, in recent years, Justice Stephen Breyer regularly advocated an incremental and case-specific analysis of First Amendment issues tied to an evaluation of "proportionality" as a way to avoid the "straitjacket" that accompanies the dichotomies of content neutrality. ${ }^{17}$ His preferred analysis would focus on whether regulation is "out of proportion to its justification" by "tak [ing] account of the seriousness of the speech-related harm the provision will likely cause, the nature and importance of the provision's countervailing objectives, the extent to which the provision will tend to achieve those objectives, and whether there are other, less restrictive ways of doing so." 18

Finally, there is the problem of coherence. Justice Anthony Kennedy, who views content neutrality as central to First Amendment doctrine, has frankly acknowledged that the doctrine has been debased in cases upholding regulation of adult entertainment venues. He has noted that "the fiction that this sort of ordinance is content neutral . . . is perhaps more confusing than helpful. . . . It is also not a fiction that has commanded our consistent adherence." ${ }^{19}$

Supreme Court opinions, moreover, have cycled among competing definitions of "content neutrality." At its inception, the doctrine was phrased conjunctively: "[s]elective exclusions from a public forum may not be based on content alone, and may not be justified by reference to content alone." ${ }^{20}$ One recurring approach, which I will

347 (1995) (invalidating prohibition on anonymous electoral publications "[w] hen a law burdens core political speech, we apply 'exacting scrutiny'”).

17 Denver Area Educ. Telcoms. Consortium v. FCC, 518 U.S. 727, 741 (1996). Justice Breyer's "straitjacket" language was joined by a plurality of Justices. Id.

18 Alvarez, 132 S. Ct. at 2551 (Breyer, J., concurring); see also Brown v. Entm't Merchs. Ass'n, 131 S. Ct. 2729, 2765-66 (2011) (Breyer, J., dissenting); Sorrell v. IMS Health Inc., 131 S. Ct. 2653, 2673-74 (2011) (Breyer, J., dissenting); Snyder v. Phelps, 131 S. Ct. 1207, 122122 (2011) (Breyer, J., concurring); United States v. Playboy Entm't Group, 529 U.S. 803, 841 (2000) (Breyer, J., dissenting).

On at least one occasion, Justice Breyer's proportionality analysis has proven more protective than a categorical hostility to content discrimination. Golan v. Holder, $132 \mathrm{~S}$. Ct. 873, 907-08 (2012) (Breyer, J., dissenting) (finding no "reasonable copyright-related justifications for the serious harms, including speech-related harms, which the Act seems likely to impose."); see also, Holder v. Humanitarian Law Project, 130 S. Ct. 2705, 2739 (2010) (Breyer, J., dissenting) (criminal prosecution of teaching humanitarian advocacy "gravely and without adequate justification injure interests of the kind the First Amendment protects").

19 City of L.A. v. Alameda Books, Inc., 535 U.S. 425, 448 (2002); see id. at 457 (Souter, J., dissenting) ("It would ... make sense to give a First Amendment label of its own."); $c f$. City of Erie v. Pap's A.M., 529 U.S. 277, 295-96 (2000); City of Renton v. Playtime Theatres, Inc., 475 U.S. 41, 60 (1986).

20 Police Dep't of Chi. v. Mosley, 408 U.S. 92, 96 (1972) (emphasis added); see Hill v. Colorado, 530 U.S. 703, 747 (2000) (Scalia, J., dissenting) ("Our very first use of the "justified 
refer to as the "strong" form of the doctrine, retains this conjunctive analysis. It begins with the face of the challenged rule, and asks if its operative terms treat speech differently depending on the content of regulated speech. ${ }^{21}$ This analysis imposes a second requirement, under which even a facially neutral rule may be "content based" if it is "justified" by hostility to particular messages. But mens rea is not a necessary condition of constitutional violation.

A competing strand of content neutrality doctrine, which I will refer to as the "weak" form, focuses solely on government motivation and/or justification and holds that " $[\mathrm{t}]$ he principal inquiry in determining content neutrality ... is whether the government has adopted a regulation of speech because of disagreement with the message it conveys. ${ }^{22}$ This strand, which inclines toward Justice Stevens' focus on sympathy or hostility, permits differential treatment on the basis of content if the differentials are justified or motivated by legitimate

by reference to content' language made clear that it is a prohibition in addition to, rather than in place of, the prohibition of facially content-based restrictions.").

21 E.g., Humanitarian Law Project, 130 S. Ct. at 2723-24 ("[Section] 2339B regulates speech on the basis of its content. Plaintiffs want to speak to the PKK and the LTTE, and whether they may do so under $§ 2339$ B depends on what they say."); Alameda Books, Inc., 535 U.S. at 448 (Kennedy, J., concurring) ("can be determined on the face of it; if the statute describes speech by content then it is content based"); City of Cin. v. Discovery Network, Inc., 507 U.S. 410, 429 (1993) ("whether any particular newsrack falls within the ban is determined by the content of the publication resting inside that newsrack... [B]y any commonsense understanding of the term, the ban in this case is "content based."); Simon \& Schuster, Inc. v. Members of the N.Y. State Crime Victims Bd., 502 U.S. 105, 115-17 (1991) (whether the rule requires "official scrutiny of the content of publications as the basis for imposing” (quoting Ark. Writers' Project, Inc. v. Ragland, 481 U.S. 221, 230 (1987))); Regan v. Time, Inc., 468 U.S. 641, 648-49 (1984) (quoting Carey v. Brown, 447 U.S. 455, 461 (1980)). See also Simon Eo Schuster, Inc., 502 U.S. at 117 ("[I]llicit legislative intent is not the sine qua non of a violation of the First Amendment." (quoting Minneapolis Star \& Tribune Co. v. Minn. Comm'r of Revenue, 460 U.S. 575, 592 (1983)); FCC v. League of Women Voters, 468 U.S. 364, 383 (1984) ("enforcement authorities must necessarily examine the content of the message that is conveyed").; cf. Hill, 530 U.S. at 747 (Scalia, J., dissenting).

22 Ward v. Rock Against Racism, 491 U.S. 781, 791 (1989); see, e.g., Sorrell, 131 S. Ct. at 2664 (quoting Ward, 491 U.S. at 791); id. (citing Renton, 475 U.S. at 48); Christian Legal Soc'y Chapter of the Univ. of Cal. v. Martinez, 130 S. Ct. 2971, 2994 (2010) ("regulation that serves purposes unrelated to the content of expression is deemed neutral") (quoting Ward, 491 U.S. at 791).

Then-Professor Robert Post remarked on the conflict among Justices over the strong and weak forms of the content neutrality doctrine a decade and a half ago. Robert Post, Recuperating First Amendment Doctrine, 47 STAN. L. REv. 1249, 1268 (1995). Post then went on to note the "pervasive ambiguity as to whether courts are to assess the justification for a regulation (the reasons that can be adduced for its passage) or the motivation for a regulation (the actual psychological intentions of those who enacted it)." Id. I will pass over this difficulty for the present. For a thoughtful and nuanced account of the various forms of the content neutrality doctrine, see Kendrick, supra note 2. 
considerations. The Court has regularly fallen into acrimonious disputes over the question of whether a particular regulation is "contentbased" or "content-neutral," and which strand of analysis should serve as the dividing line..$^{23}$ A similar perplexity has afflicted the lower courts. ${ }^{24}$

A platoon of commentators has also deployed against the doctrine. Some decry the failure of the content neutrality framework to map important theoretical commitments ${ }^{25}$ or practical distinctions. ${ }^{26}$ Another strain of critique laments that the approval of "content neutral" regulations leaves too much room for government regulations that interfere with free expression. ${ }^{27}$ Its counterpoint argues that the

23 E.g., Martinez, 130 S. Ct. at 2994; id. at 3015-20 (Alito, J., dissenting); Hill, 530 U.S. at 719-20; id. at 743-45 (Scalia, J., dissenting); Turner Broad. Sys. v. FCC, 512 U.S. 622, 642-43 (1994); id. at 678 (O'Connor, J., dissenting); United States v. Kokinda, 497 U.S. 720, 736 (1990); id at 739 (Kennedy, J., concurring in judgment); id at 753 (Brennan, J., dissenting)

24 For a particularly striking divergence of definition playing out recently in one circuit, compare Al Haramain Islamic Found., Inc. v. U.S. Dep't of the Treasury, 686 F.3d 965, 1000-01 (9th Cir. 2012) (strong form), Minority Television Project, Inc. v. FCC, 676 F.3d 869, 874 (9th Cir. 2012) (strong form) rev'd en banc, 736 F.3d 1192, 1198 (9th Cir. 2013) (strong form, but avoiding strict scrutiny on other grounds), Hoye v. City of Oakland, 653 F.3d 835, 851 (9th Cir. 2011) (strong form), Berger v. City of Seattle, 569 F.3d 1029, 1051 (9th Cir. 2009) (strong form), and G.K. Ltd. Travel v. City of Lake Oswego, 436 F.3d 1064, 1071 (9th Cir. 2006) (strong form), with Reed v. Town of Gilbert, 707 F.3d 1057, 1073 (9th Cir. 2013) (weak form), United States v. Chi Mak, 683 F.3d 1126, 1134 (9th Cir. 2012) (weak form), Comite de Jornaleros de Redondo Beach v. City of Redondo Beach, 657 F.3d 936, 944-45 (9th Cir. 2011) (Smith, J.,) (assuming weak form), and id. at 951 (Smith, J., concurring with himself) (strong form).

25 See, e.g., Larry A. Alexander, Trouble on Track Two: Incidental Regulations of Speech and Free Speech Theory, 44 HASTINGS L.J. 921, 944-953 (1993) (theoretical mismatch: "protects more speech than it can justify protecting", and requires inappropriate interventions); Jed Rubenfeld, The First Amendment's Purpose, 53 STAN. L. REv. 767, 776 (2001) ("The only real First Amendment question in these cases is whether the state's purpose was to punish someone for speaking."); R. George Wright, Content-Based and Content-Neutral Regulation of Speech: The Limitations of a Common Distinction, 60 U. MiamI L. Rev. 333, 364 (2006) ("[N]either simple nor complex forms of the distinction serve as a useful proxy for the underlying values about which society cares most.").

26 See, e.g., Frederick Schauer, Harm(s) and the First Amendment, 2011 Sup. Ct. Rev. 81, 97 (2011) ("immature state of doctrine") [hereinafter Schauer, Harm(s) and the First Amendment]; Schauer, supra note 2, at 1270 ("[C] onflation of the morally and politically divergent in the service of avoiding content-based or viewpoint-based distinctions explains much of the unalterable core of the First Amendment."); Mark Tushnet, The First Amendment and Political Risk 3 (Harv. Law Sch. Pub. Law \& Legal Theory Working Paper Series, Paper No. 12-12, 2012), available at $\mathrm{http}: / /$ papers.ssrn.com/sol3/papers.cfm?abstract_id= 2031258 ("[T] he courts' assessment of the risk that speech causes harm seems mistaken[.]").

27 See, e.g., Edward L. Carter \& Brad Clark, The Death of Procedural Safeguards: Prior Restraint, Due Process and the Elusive First Amendment Value of Content Neutrality, 11 COMM. L. \& POL'Y 225, 227 (2006); Martin H. Redish, The Content Distinction in First Amendment Analysis, 34 StAN. L REv. 113, 114-25 (1981); Susan H. Williams, Content Discrimination and the First 
presumptive invalidity of "content discrimination" leaves the government powerless to deal with speech that legitimately threatens public values. $^{28}$ Others contend that in avoiding over and under inclusiveness, the Court has tortured the distinction into result-driven incoherence. ${ }^{29}$

Some commentators level all attacks simultaneously. ${ }^{30}$

\section{Incomplete Defenses}

So what is to be said for a doctrine of content neutrality? Justice Antonin Scalia's opinion in R. A. V. v. City of St. Paul constitutes the locus classicus of the doctrine in the last generation. ${ }^{31}$ It advances two concerns to justify the focus on content neutrality. First, the presumption against content based regulation can be rooted in a perception that content based regulations are likely to be motivated by official hostility to particular viewpoints. The danger that "the selectivity of the restriction is ... conditioned upon the sovereign's agreement with what a speaker may intend to say" supports a prophylactic demand that content based regulations invoke special justifications. ${ }^{32}$ Conversely, content based regulations may be sustained where judges

Amendment, 139 U. PA. L. REv. 615, 617 (1991); Timothy Zick, Speech and Spatial Tactics, 84 TEX. L. REV. 581, 583 (2006).

28 See, e.g., Patrick M. Garry, A New First Amendment Model for Evaluating Content-Based Regulation of Internet Pornography: Revising the Strict Scrutiny Model to Better Reflect the Realities of the Modern Media Age, 2007 BYU L. REV. 1595, 1597 (2007).

29 See, e.g., Chemerinsky, supra note 2, at 54-55 (quoting United States v. Playboy Entm't Group, 529 U.S. 811 (2000); id. at 50; Garry, supra note 28 at 1600-01; Don Herzog, The Kerr Principle, State Action, and Legal Rights, 105 MiCH. L. Rev. 1, 12-13 (2006); Dan V. Kozlowski, Content and Viewpoint Discrimination: Malleable Terms Beget Malleable Doctrine, 13 COMM. L. \& POL'Y 131, 132 (2008).

30 See, e.g., Barry P. McDonald, Speech and Distrust: Rethinking the Content Approach to Protecting the Freedom of Expression, 81 NOTRE DAME L. REv. 1347, 1352-53 (2006) ("On the one hand, it unreasonably ties the government's hands in regulating certain forms of content that give rise to special problems... .where those regulations present little risk of illegitimate government motivation or censorship .... On the other hand, it fails to adequately address the risk to free expression posed by content-neutral regulations that might impose significant burdens .... [The doctrine exacts] a significant cost in terms of their ad hoc and uncertain application .... applied in an inconsistent and results-driven manner by the Court.").

31 R.A.V. v. City of St. Paul, 505 U.S. 377, 390 (1992). R.A.V. provided the springboard for then-Professor Kagan's analysis. See Kagan, Private Speech, Public Purpose, supra note 1; Kagan, Regulation of Hate Speech and Pornography After R.A.V., supra note 1.

32 R.A.V., 505 U.S.at 390 (internal quotation marks and citation omitted). Then-Professor Kagan's exposition of the importance of content neutrality argues that an official desire to privilege some ideas or suppress others renders an action a violation of the First Amendment, and the distinction "facilitates the effort to flush out improper purposes." Kagan, Private Speech, Public Purpose, supra note 1 at 451. See id. at 437, 441 ("to "ferret out" improper purposes). 
seeking clues of censorial motive are convinced that "the nature of the content discrimination is such that there is no realistic possibility that official suppression of ideas is afoot. ${ }^{" 33}$ This emphasis underpins what I have referred to as the "weak" version of the doctrine.

Second, content based regulations are said to particularly threaten distortion in the marketplace of ideas. "The rationale of the general prohibition .... is that content discrimination 'raises the specter that the Government may effectively drive certain ideas or viewpoints from the marketplace[.] ",34 Since the focus is on the impact of dis tortion, rather than simply the motive of hostility, this account inclines toward the strong form of the doctrine.

As critics regularly observe, both arguments are seriously incomplete. The notion that basic constitutional principle renders illegitimate every official action motivated by hostility or enthusiasm for particular viewpoints is not firmly rooted in many of the classic rationales for protection of free expression. The marketplace of ideas, individual autonomy of intellect, and the function of checking government can all be impeded no less by official misfeasance than by official malfeasance, and ineffectual government hostility threatens none of them. If official hostility per se is the object of constitutional opprobrium-and the prohibition on "content-based" regulations primarily seeks to bar hostile motivation-then a series of prominent constitutional landmarks are profoundly misplaced.

The prohibition on mutilating draft cards upheld as content neutral in United States v. O'Brien was manifestly rooted in hostility to the

33 R.A.V., 505 U.S. at 390. See Davenport v. Wash. Educ. Ass'n, 551 U.S. 177, 189 (U.S. 2007) (quoting R.A.V., 505 U.S. at 390). But of. Hill v. Colorado, 530 U.S. 703, 743 (2000) (Scalia, J., dissenting) ("'illicit legislative intent is not the sine qua non of a violation of the First Amendment.” (quoting Madsen v. Women's Health Ctr., 512 U.S. 753, 794 (1994) (Scalia, J., dissenting))). See generally SIR A. CONAN DOYLE, The Adventure of the Abbey Grange, in The Return of Sherlock Holmes 319, 319 (1905) ("Come, Watson, come! . . . The game is afoot.").

34 R.A.V., 505 U.S. at 387 (quoting Simon E Schuster, 502 U.S. at 116 (1991)). See, e.g., Turner Broad. Sys. Inc. v. FCC, 512 U.S. 622, 641 (1994) (quoting R.A.V., 505 U.S. at 382-83); Leathers v. Medlock, 499 U.S. 439, 448 (1991); FCC v. League of Women Voters, 468 U.S. 364,384 (1984).

This locution of this justification for content neutrality appears to originate with Professor Geoffrey R. Stone. See, e.g., Geoffrey R. Stone, Content Neutral Restrictions, 54 U. CHI. L. Rev. 46, 54-57 (1987); Stone, Content Regulation and the First Amendment, supra note 6, at 202, 246. However, the trope can be traced through Police Dep't of Chicago v. Mosley in 1972 to Alexander Meiklejohn's work in 1948. See Police Dep't of Chi. v. Mosley, 408 U.S. 92, 96 n.4 (1972) (citing Alexander Meiklejohn, Political FreEdom: The Constitutional Powers of The People 27 (1948)). Meiklejohn advanced claims for "equality of status in the field of ideas" and concerns about "mutilation of the thinking process of the community[.]" MEIKLEJOHN at 26 (emphasis omitted). 
message of draft card burners. ${ }^{35}$ Constitutionally approved efforts to contain abortion protesters arise out of concerns regarding the impact of the content of those protests on the targets of their communication. ${ }^{36}$ The Court has upheld efforts to quarantine sexually explicit entertainment as "content neutral" notwithstanding the extraordinary correspondence of those efforts with the view that sexualized messages are repugnant. ${ }^{37}$

The Roberts Court has sustained a series of flagrantly viewpoint based regulatory actions. Criminalizing efforts to teach international law to disfavored guerilla groups, ${ }^{38}$ punishing students for speech that could be construed to encourage drug use, ${ }^{39}$ depriving prisoners of newspapers, ${ }^{40}$ barring public employee unions from receiving political contributions, ${ }^{41}$ prosecuting bystanders in retaliation for criticism of the vice president, ${ }^{42}$ and disciplining a public employee for having the temerity to criticize unconstitutional actions by his superiors on the job ${ }^{43}$ all have survived review.

And, of course, officials regularly allocate resources to favor views of which they approve and to combat views of which they disapprove. Government officials require students to attend viewpoint discriminatory schools. Voter education campaigns, like official adjurations to "Just say no to drugs," or efforts to teach tolerance, are uncontroversially consistent with the First Amendment. The notion that deeply embedded constitutional norms of free expression bar government officials from acting on a desire to suppress or advance particular viewpoints blinks reality. ${ }^{44}$

35 United States v. O’Brien, 391 U.S. 367, 387 (1968) (quoting legislative history, "The House Committee on Armed Services is fully aware of, and shares in, the deep concern expressed throughout the Nation over the increasing incidences in which individuals and large groups of individuals openly defy and encourage others to defy the authority of their Government by destroying or mutilating their draft cards.").

36 E.g. Hill, 530 U.S. at 734; Frisby v. Schultz, 487 U.S. 474, 488 (1988).

37 See, e.g., City of Erie v. Pap's A.M., 529 U.S. 277, 298 (2000); City of Renton v. Playtime Theatres, Inc., 475 U.S. 41, 53 (1986).

38 Holder v. Humanitarian Law Project, 130 S.Ct. 2705, 2731 (2010).

39 Morse v. Frederick, 551 U.S. 393, 403 (2007).

40 Beard v. Banks, 548 U.S. 521,533 (2006).

41 Davenport v. Wash. Educ. Ass'n, 551 U.S. 177, 189 (2007).

42 Reichle v. Howards, 132 S.Ct. 2088, 2097 (2012).

43 Garcetti v. Ceballos, 548 U.S. 410, 422-23, 426 (2006).

44 For an extended and effective version of this critique, see John Fee, Speech Discrimination, 85 B.U.L. REv. 1103, 1143-46, 1150-55 (2005).

To be fair, then-professor Kagan acknowledged that "motive-based" First Amendment analysis did not necessarily apply to government functioning as "speaker, employer, and educator[.]" See Kagan, Private Speech, Public Purpose, supra note 1, at 425, 432. However, it is difficult to discern why an invidious motivation is less disqualifying in those roles unless impact rather than motivation is really at issue. Justice Scalia implied as much in 
Conversely, the volumes of United States Reports echo with the observation that "our cases have consistently held that '[i]llicit legislative intent is not the sine qua non of a violation of the First Amendment." ${ }^{45}$ The constitutional canon contains a distinguished roster of cases that have invalidated government rules motivated by something other than hostility to particular viewpoints. ${ }^{46}$ And regulations are regularly denoted "content based" en route to invalidation despite an absence of any indication of government hostility to particular mes-

Davenport 551 U.S. at 188 ("[T] he rationale of the general prohibition ... is that content discrimination 'raises the specter that the Government may effectively drive certain ideas or viewpoints from the marketplace.'... [W] e have identified numerous situations in which that risk is inconsequential, so that strict scrutiny is unwarranted.").

45 Simon \& Schuster, Inc. v. Members of the N. Y. State Crime Victims Bd., 502 U.S. 105, 117 (1991) (quoting Minneapolis Star \& Tribune Co. v. Minnesota Comm'r of Revenue, 460 U.S. 575, 592 (1983)). See also Madsen v. Women's Health Ctr., 512 U.S. 753, 794 (1994) (Scalia, J., concurring) (quoting Simon $\mathcal{E}$ Schuster, 502 U.S. at 117); Turner Broad. Sys. v. FCC, 512 U.S. 622, 642 (1994) (quoting Minneapolis Star, 460 U.S. at 592); Leathers v. Medlock, 499 U.S. 439, 445 (1991) (quoting Minneapolis Star, 460 U.S. at 592); Forsyth Cnty. v. Nationalist Movement, 505 U.S. 123, 134 (1992); $c f$. Citizens United v. FEC, 558 U.S. 310, 340 (2010) ("[P]olitical speech must prevail against laws that would suppress it, whether by design or inadvertence.").

46 E.g. Snyder v. Phelps, 562 U.S. 1, 12-13 (2011) (imposition of liability for intentional infliction of emotional distress); Watchtower Bible \& Tract Soc'y of N.Y., Inc. v. Vill. of Stratton, 536 U.S. 150, 165-66 (2002) (requirement of permit for door to door canvassing); United States v. Nat'l Treasury Emps. Union, 513 U.S. 454, 457, 480 (1995) (prohibition of collection of speakers fees by federal employees); City of Ladue v. Gilleo, 512 U.S. 43, 55-58 (1994) (prohibition of erecting window signs); Butterworth v. Smith, 494 U.S. 624, 635-636 (1990) (prohibition of disclosure of personal grand jury testimony); United States v. Grace, 461 U.S. 171, 183 (1983) (prohibition of all demonstrations on sidewalks surrounding the Supreme Court); NAACP v. Claiborne Hardware Co., 458 U.S. 886, 926 (1982) (imposition of liability for tortious interference with business by boycott which involved violence); In re Primus, 436 U.S. 412, 431 (1978) (liability for recruitment of plaintiffs applied to public interest attorneys); Buckley v. Valeo, 424 U.S. 1, 143 (1976) (viewpoint neutral prohibition of selffunded campaign advertising); Cohen v. California, 403 U.S. 15, 16 (1971) (prosecution for disturbing the peace by using the word "fuck"); United Mine Workers v. Pennington, 381 U.S. 657, 611 (1965) (antitrust liability for concerted efforts to influence government officials); N.Y. Times Co. v. Sullivan, 376 U.S. 254, 264-65, 279-80 (1964) (imposition of liability for speech which is false but lacks "actual malice”); E. R.R. Presidents Conference v. Noerr Motor Freight, Inc., 365 U.S. 127, 136 (1961) (antitrust liability for petitioning the government); Talley v. California, 362 U.S. 60,64 (1960) (prohibition of anonymous brochures); NAACP v. Button, 371 U.S. 415, 433 (1963) (prohibition of solicitation of clients by public interest attorneys); Shelton v. Tucker, 364 U.S. 479, 488-90 (1960) (compelled disclosure by teachers of organizational membership); NAACP v. Alabama ex rel. Patterson, 357 U.S. 449, 466 (1958) (compelled disclosure of membership lists); Schneider v. State, 308 U.S. 147, 163-65 (1939) (uniform prohibition of distributing leaflets); see, Ariz. Free Enter. Club's Freedom Club PAC v. Bennett, 131 S. Ct. 2806, 2813 (2011) (grant of state funding to all opponents of lavishly self-funded campaigns); Davis v. FEC, 554 U.S. 724, 729-31 (2008) (grant of advantageous contribution limits to all opponents of lavishly self-funded campaigns). 
sages. ${ }^{47}$ A search for illicit motivation thus provides an uncertain foundation upon which to build an account of content neutrality doctrine.

The alternative justification that content based regulations may excise unwelcome views from the public sphere is firmly rooted in core conceptions of the role of free speech in American democracy. ${ }^{48}$ As applied to the standard fare of content neutrality, however, the concern that content based regulations justified by some legitimate but not overwhelming public purpose will undercut the foundation of self governance or "drive ideas from the marketplace" often seems overwrought. ${ }^{49}$ To take examples from the Roberts Court, does anyone seriously believe that fraudulent claims of military honors, the broadcast of crude prime time language, violent video games, unrestrained drug company hucksterism, personal vitriol directed at grieving parents, dogfight videos, and unrestricted corporate contributions are the only barriers-or even significant barriers-standing bebetween American society and emerging dictatorship, government controlled public discourse, or suppression of individual identity? $?^{50}$

47 E.g., Citizens United, 558 U.S. at 318 (viewpoint neutral prohibition on corporate campaign contributions); United States v. Playboy Entm't Group, 529 U.S. 803, 806 (2000) (restraint on all cable stations carrying sexually oriented programming); McIntyre v. Ohio Elections Comm'n, 514 U.S. 334, 345 (1995) ("[E]ven though this provision [forbidding anonymous leaflets] applies evenhandedly to advocates of differing viewpoints, it is a direct regulation of the content of speech.”); Simon $\mathcal{E}$ Schuster, 502 U.S. at 108 (limitation of author's access to proceeds of writings describing author's crimes); FCC v. League of Women Voters, 468 U.S. 364, 366 (1984) (prohibition of editorials by public broadcasters); Regan v. Time, Inc., 468 U.S. 641, 643, 647 (1984) (prohibition of printed reproduction of federal currency unless "used for philatelic, numismatic, educational, historical, or newsworthy purposes”); Carey v. Brown, 447 U.S. 455, 461 (1980) (prohibition of residential picketing except in cases of labor disputes).

48 See, e.g., Robert C. Post, Democracy, Expertise, and ACAdemic Freedom: A First AMENDMENT JURISPRUdENCE FOR THE MODERn STATE 22, 28 (2012) ("First Amendment prohibitions against viewpoint and content discrimination ... reflect[] the premise that in a democracy every subject of law possesses an equal right to seek to shape the content of public opinion."); James Weinstein, Hate SPEECH, PORNOGRAPHY AND THE RADICAL ATtaCK ON Free SPEECH Doctrine 40-43 (1999); James Weinstein, Participatory Democracy as the Central Value of American Free Speech Doctrine, 97 VA. L. REV. 491, 513-14 (2011).

49 See Kagan, Private Speech, Public Purpose, supra note 1, at 419-21 (observing of R.A.V. v. City of St. Paul, 505 U.S. 377, 390 (1992), that "on close inspection, this argument appears contrived.... [T] he statute would not dangerously have distorted public debate.")

Kagan argued both that the "skewing effect" of punishing racial insults but not others "is very modest" and that an argument about "skewing" improperly assumes the distortions of private origin do not "skew" debate. See id. at 419-20, 446-450, 455; see, e.g., McDonald, supra note 30, at 1367 ("little risk" of government manipulation of the marketplace of ideas); $i d$. at 1388 (minor burdens on expressive freedoms).

$50 \quad$ See United States v. Alvarez, 132 S. Ct. 2537 (2012); FCC v. Fox TV Stations, Inc., 132 S. Ct. 2307 (2012); Brown v. Entm’t Merchs. Ass'n, 131 S. Ct. 2729 (2011); Sorrell v. IMS 
Perhaps the day to day implementation of free speech in the federal courts serves primarily to edify civil libertarians. Or perhaps, as Justice Sandra Day O'Connor suggested in tones redolent of Winston Churchill's defense of democracy, "regulations are occasionally struck down because of their content based nature, even though common sense may suggest that they are entirely reasonable [because ] . . no better alternative has yet come to light.. ${ }^{51}$

This Article maintains that the case for content neutrality has firmer, if partially buried, foundations.

\section{Good Enough for Government Work: Content Neutrality as Norm and Heuristic}

The core question for first amendment doctrine should be neither whether every application preserves the essence of democratic discourse and self realization nor whether all "common sense" or "proportionate" regulations survive its strictures. Rather, attention should focus on the extent to which the doctrine contributes to a system of norms which preserve the reality of free expression in American society. On this metric, content neutrality scores well.

This defense of content neutrality begins with Alexander Hamilton's observation that "security" for "liberty of the press" (and by the same token for speech and assembly), "whatever fine declarations may be inserted in any constitution respecting it, must altogether depend on public opinion, and on the general spirit of the people and of the government." ${ }^{, 52}$ Hamilton overstates the matter; judicial review can sometimes overcome public opinion. But how effectively a doctrine inclines the "general spirit of the people and of the government" to the protection of rights of free expression is a crucial question.

Guided by this inquiry, I begin by exploring how the content neutrality doctrine today functions to constrain and guide the officials who encounter it on the ground. I then examine, in the circumstances in which content neutrality doctrine is predominantly deployed, whether it is calculated to instill an inclination to protect free expression in "the spirit of the government" and "of the people." I conclude that strong content neutrality requirements better impart,

Health Inc., 131 S. Ct. 2653 (2011); Snyder v. Phelps, 131 S. Ct. 1207 (2011); United States v. Stevens, 130 S. Ct. 1577 (2010); Citizens United v. FEC, 558 U.S. 310 (2010).

51 City of Ladue v. Gilleo, 512 U.S. 43, 59-60 (O'Connor, J., concurring).

52 The Federalist No. 84, at 535 (Alexander Hamilton) (Benjamin Fletcher Wright ed., 1961). 
cultivate, and enforce this inclination than the competing frameworks of either "ferreting out" intolerant government motives or adjuring government to limit its censorship to "proportionate" means.

\section{A Census of CONTENT NeUtrality in ACTION}

Academic discussions of content neutrality regularly examine or explicate the doctrine in terms of decisions reached by the Supreme Court. $^{53}$ But most legal controversies never reach the Court. The working elements of "content neutrality," like those of many other doctrines, may be quarried in the Justices' opinions, but they are hammered out elsewhere. The law of content neutrality on the books includes not only the cases decided by the Supreme Court, but the much larger array of lower court cases that officials, citizens, and their lawyers consult in seeking to parse their legal rights and responsibilities. The law in action is formed by the impact of the entire constellation of precedent on the decisions and sensibilities of the citizens and officials.

This section examines the patterns that emerge when the field of examination expands from the Supreme Court to the rest of the federal judiciary. I have gathered the 713 reported cases in the lower federal courts during the four year period from September 2009 to August 2013 which deploy the term "content neutrality" or its cognates in the context of free expression claims brought by plaintiffs represented by counsel. ${ }^{54}$ This group includes 233 cases from the

53 Then-professor Kagan, for example, in Private Speech, Public Purpose, supra note 1, at 516, sought to explain the tapestry of existing Supreme Court cases by interpreting content neutrality as a mechanism for "ferreting out" improper purposes. See also, e.g., Srikanth Srinivasan, Incidental Restrictions of Speech and the First Amendment: A Motive-Based Rationalization of the Supreme Court's Jurisprudence, 12 CONST. COMMENT. 401, 420 (1995). Professor McDonald updated and critiqued Professor Kagan's efforts in McDonald, supra note 30. Professor Kendrick, in Content Discrimination Revisited, supra note 2, recently returned to the same well, replenished by another decade of cases, seeking to generate a "real" definition of content neutrality.

54 Appendix III sets forth details of the methodology.

The choice to review published opinions will offend some methodologists. Reported cases do not constitute a fully representative sample of the cases resolved by the federal courts. For a good investigation of the divergence between reported opinions and district court resolutions, see David A. Hoffman et al., Docketology, District Courts and Doctrine, 85 WASH. U. L. REV. 681 (2007) (finding that opinion writing probability varies from $10 \%$ to $60 \%$ depending on the jurisdiction and type of case). See also Margo Schlanger \& Denise Lieberman, Using Court Records for Research, Teaching, and Policymaking: The Civil Rights Litigation Clearinghouse, 75 UMKC L. REv 155, 163-65 (2006) (8.7\% of terminated cases in federal district courts involved written decisions and $2.3 \%$ had reported decisions).

In thinking about law in action, however, a census of reported cases in the lower federal courts is more informative than the usual fodder of recycled Supreme Court chest- 
courts of appeals and 480 cases from the district courts. I compare them with the thirty-seven First Amendment cases decided by the Roberts Court between 2005 and 2013.

This comparison highlights four ways in which a focus on the Roberts Court's First Amendment caseload differs from the content neutrality cases decided by the lower federal courts.

(1) In the Roberts Court, less than a third of cases involved decisions by local officials or street level bureaucrats; two thirds concerned state or federal statutes or regulations of general applicability. Only two of the fifteen successful cases involved what Justice Robert Jackson referred to as "village tyrants." lenges to village tyrants accounted for almost two thirds of the cases decided in the courts of appeals, and almost three quarters of the cases decided in the district courts.

(2) Before the Roberts Court, the bulk of litigants invoking content neutrality, and the vast majority of successful litigants, were corporations, large nonprofits, businesses, and wealthy campaign participants. By contrast, in the lower courts, mainstream businesses and large institutional players accounted for less than one successful case in ten. Cases involving idiosyncratic individual dissenters, religious plaintiffs, and local ideological plaintiffs of the Left and Right accounted for $79 \%$ of the lower court sample and $88 \%$ of successful claimants. While the majority of sampled cases did not report the presence of ideological counsel, $31 \%$ of all cases and almost two thirds of cases involving ideological plaintiffs involved representation by movement affiliated or public interest lawyers of the Left or Right.

nuts. More importantly, for lawyers seeking to advise their clients, officials seeking to guide themselves by the law, and citizens seeking a sense of their legal rights, reported cases constitute the primary source to consult. Cases decided by consent or without opinion simply will not have much impact outside of the actions of the parties. The same is true of pro se cases, which regularly frame claims that lack discernible legal arguments and almost inevitably result in opinions that are uninformative to lawyers, officials, and citizens.

This is an appropriate point at which to disclose a set of experiences that will inform (or taint) my analysis. I began serving as a cooperating attorney for the Philadelphia ACLU in 1979, and since 2004, I have served as chair of the Philadelphia ACLU Legal Committee. In those roles, I have found that while what the Supreme Court has said over the last thirty years is important, what the Third Circuit and the Eastern District of Pennsylvania have officially held in the half decade before litigation is usually crucial.

55 See infra note 57 and accompanying text. 
(3) Before the Roberts Court, cases involving election law accounted for almost a third of case load; before lower courts, these cases represented only $5 \%$ of content neutrality cases. By contrast, public forum and limited public forum cases, almost absent at the Supreme Court level, made up the second and third most frequent types of content neutrality cases before the lower courts. The bulk of the public forum litigants were either local dissidents of the Left or Christian activists. In limited public forum cases, the modal litigant was an unaffiliated individual.

(4) Consistent with Supreme Court doctrine, though not consistent Supreme Court practice, lower courts appeared to evaluate content neutral burdens on speech with some seriousness. A focus on the apparently unbroken series of Supreme Court cases sustaining content neutral burdens is thus misleading.

\section{A. Village Tyrants}

In West Virginia State Board of Education v. Barnette, during first flower of the Supreme Court's commitment to free speech, Justice Robert Jackson confronted Justice Felix Frankfurter's argument that a schoolchild's obligation to recite the pledge of allegiance was not a matter that should occupy the Court. Frankfurter maintained that the controversy was a mere example of "the difficulties and complexities that confront states in the duty of administering their local school systems. ${ }^{, 56}$ Jackson responded,

Such Boards are numerous and their territorial jurisdiction often small. But small and local authority may feel less sense of responsibility to the Constitution, and agencies of publicity may be less vigilant in calling it to account... There are village tyrants as well as village Hampdens, but none who acts under color of law is beyond reach of the Constitution. ${ }^{57}$

56 W. Va. State Bd. of Educ. v. Barnette, 319 U.S. 624, 660 (1943) (Frankfurter, J., dissenting).

57 Barnette, 319 U.S. at 637-38.

With this language, it appears that Justice Jackson was invoking Thomas Gray's eighteenth-century poem, Elegy Written in a Country Church Yard, in THE COMPLETE POEMS OF THOMAS GraY 39, lines 45, 57-60 (Starr \& Hendrickson eds., 1966), available at http://www.thomasgray.org/cgi-bin/display.cgi?text=elcc.

Perhaps in this neglected spot is laid ...

Some village-Hampden, that with dauntless breast

The little Tyrant of his fields withstood;

Some mute inglorious Milton here may rest

Some Cromwell guiltless of his country's blood. 
Justice Jackson notwithstanding, a contemporary observer of the free expression cases in the Supreme Court might well conclude that village tyrants are not the primary targets and audience. In the Roberts Court cases, only $29 \%$ involved decisions by local officials or street level bureaucrats as opposed to state or federal statutes or regulations of general applicability. Only two of the fifteen successful cases (13\%) involved a village tyrant. ${ }^{58}$

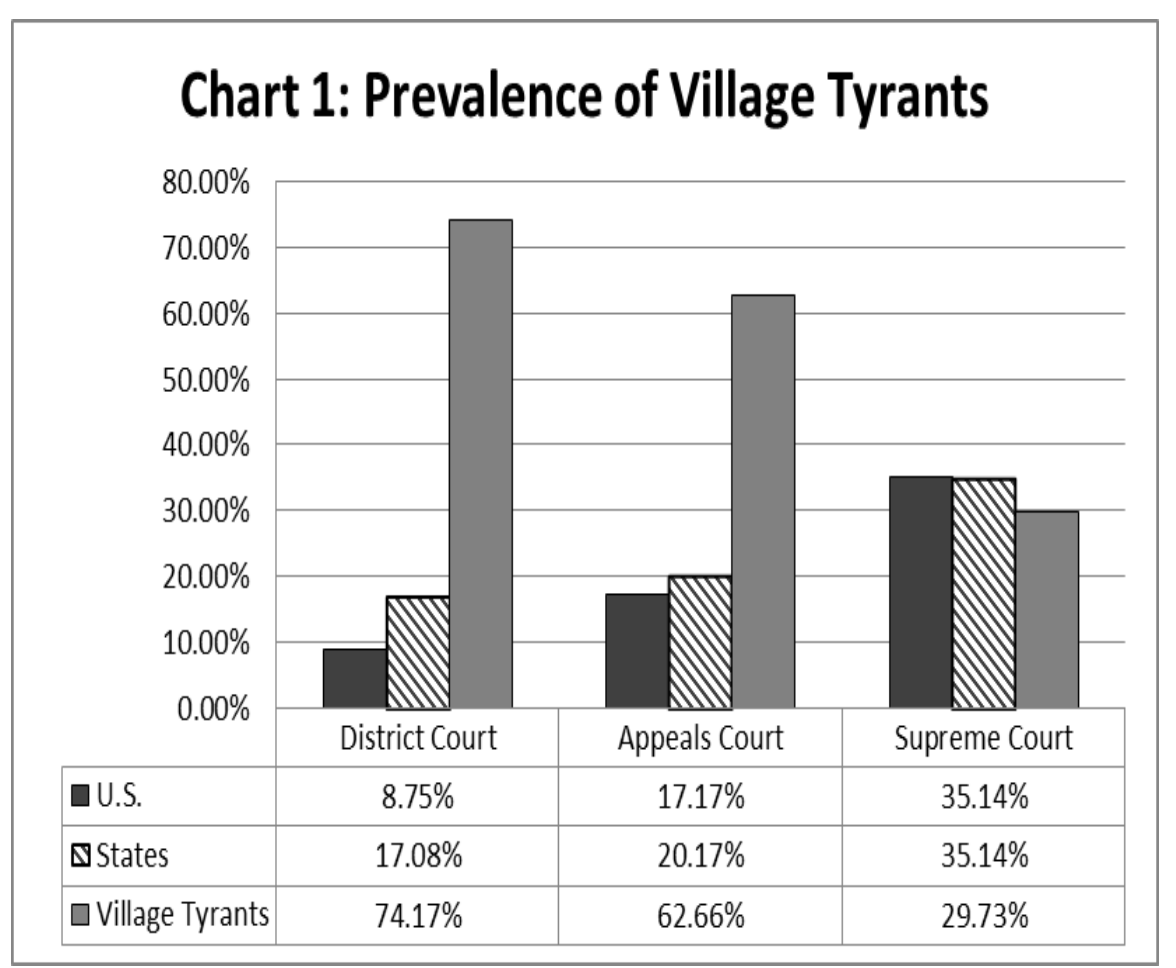

Things look quite different in the lower courts: village tyrants predominate. In the recent four year sample of content neutrality cases, challenges to village tyrants accounted for $62 \%$ of the cases decided in the courts of appeals, and $74 \%$ of the cases decided in the district courts. Local governments and street level bureaucrats ac-

58 The two cases are: Lefemine v. Wideman, 133 S. Ct. 9 (2012) (involving police officers) and Snyder v. Phelps, 131 S. Ct. 1207 (2011) (involving a state jury verdict). In dividing cases, I have grouped decisions made by street level bureaucrats together whether they are state, federal, or local officials. The constraints, norms, and incentives of an FBI agent or state trooper are more similar to those of a local police officer than to those of a state or federal legislature or regulatory agency. 
count for a similar preponderance of cases in which the lower courts sustain claims of First Amendment violations.

The result should not surprise. Most residents of the United States interact with police officers, school principals, and housing inspectors far more often than they encounter constraints imposed by administrative agencies of broad jurisdiction, by state or by federal statutes. ${ }^{59}$ We might well expect the exercise of the Supreme Court's discretionary jurisdiction, by contrast, to winnow out cases involving local issues and exercises of discretion by street level bureaucrats as not worth the Justices' time. Matters of broad state or federal regulation are more likely than the actions of village tyrants to generate the resources necessary to pursue certiorari successfully. And, even assuming equal levels of advocacy, the Justices are more likely to grant review in cases where the challenged action has broader import.

Almost all of the lower court cases invoking content neutrality in a public forum involved village tyrants, as did cases addressing schools, public meetings, billboards, public employees, and retaliation, as well as $80 \%$ of cases involving limited public forums. By contrast, village tyrants figured in only $50 \%$ of cases involving direct regulation of primary conduct allegedly justified either because the conduct was particularly dangerous or because it lacked communicative value, $45 \%$ of cases involving unconstitutional conditions and government speech, $26 \%$ of commercial speech cases, $4 \%$ of campaign cases, and no cases involving regulation of telecommunications. 


\begin{tabular}{|lrrr|}
\hline Case Type & \%Village & \% States & \% U.S. \\
\hline Billboard & $100.00 \%$ & $0.00 \%$ & $0.00 \%$ \\
\hline Campaign & $4.00 \%$ & $84.00 \%$ & $12.00 \%$ \\
\hline Commercial Speech & $26.32 \%$ & $36.84 \%$ & $36.84 \%$ \\
\hline Employees & $96.43 \%$ & $3.57 \%$ & $0.00 \%$ \\
\hline $\begin{array}{l}\text { Gov't/ Unconstitu- } \\
\text { tional }\end{array}$ & $45.71 \%$ & $14.29 \%$ & $40.00 \%$ \\
\hline Limited Public Forum & $80.90 \%$ & $13.48 \%$ & $5.62 \%$ \\
\hline Public Forum & $91.97 \%$ & $8.03 \%$ & $0.00 \%$ \\
\hline Public Meetings & $96.88 \%$ & $3.13 \%$ & $0.00 \%$ \\
\hline Retaliation & $100.00 \%$ & $0.00 \%$ & $0.00 \%$ \\
\hline School & $98.21 \%$ & $1.79 \%$ & $0.00 \%$ \\
\hline Telecom & $0.00 \%$ & $0.00 \%$ & $100.00 \%$ \\
\hline Direct Regulation & $50.43 \%$ & $24.79 \%$ & $24.79 \%$ \\
\hline Prisoners & $100.00 \%$ & $0.00 \%$ & $0.00 \%$ \\
\hline & & & \\
\hline
\end{tabular}

\section{B. Village Hampdens}

\section{The Prevalence of Village Hampdens}

Justice Jackson's reference to "village Hampdens" is apt to puzzle contemporary readers. In the Anglophilic legal milieu of 1943, the allusion was probably clearer. John Hampden gained fame as a critic and political opponent of King Charles I of England; Hampden's principled opposition to ship money levies triggered widespread re- 
sistance and ultimately the overthrow of the monarchy regarded by the American Framers as an archetype of tyranny. ${ }^{60}$ Justice Jackson's borrowed allusion implied that idiosyncratic resistance to local overreaching erects a potentially valuable bulwark against tyrannical government.

Examination of successful First Amendment litigants before the Roberts Court reveals a dearth of village Hampdens. The successful litigants did include an idiosyncratic serial liar represented by a public defender ${ }^{61}$ fringe religious enthusiasts, ${ }^{62}$ small town anti-abortion protestors, ${ }^{63}$ and a small time purveyor of dog-fight videos. ${ }^{64}$ Far more frequently, however, successful litigants were corporations, large nonprofits, businesses, and wealthy campaign participants. ${ }^{65}$ Village Hampdens were not absent, but they disproportionately populated the ranks of losing First Amendment claimants before the Roberts Court. ${ }^{66}$

60 See, e.g., Robert J. Reinstein, The Limits of Executive Power, 59 AM. U.L. REV. 259, 274-275 (2009) (and sources cited).

61 United States v. Alvarez, 132 S. Ct. 2537 (2012).

62 Phelps, 131 S. Ct. 1207.

63 Wideman, 133 S. Ct. 9.

64 United States v. Stevens, 533 F.3d 218, 221 (3d Cir. 2008) aff'd, 559 U.S. 460 (2010) (Stevens narrated the videos himself, advertised them in "an underground publication featuring articles on illegal dogfighting[,]" and sold them out of his home).

65 Agency for Int'l Dev. v. Alliance for Open Soc'y Int'l, Inc., 133 S. Ct. 2321 (2013); Am. Tradition P'ship v. Bullock, 132 S. Ct. 2490 (2012) (per curiam); FCG v. Fox Television Stations, Inc., 132 S. Ct. 2307 (2012); Ariz. Free Enter. Club's Freedom Club PAC v. Bennett, 131 S. Ct. 2806 (2011); Brown v. Entm’t Merchs. Ass'n, 131 S. Ct. 2729 (2011); Sorrell v. IMS Health Inc., 131 S. Ct. 2653 (2011); Citizens United v. FEC, 558 U.S. 310 (2010); FCC v. Fox Television Stations, Inc., 556 U.S. 502 (2009); Davis v. FEC, 554 U.S. 724 (2008); FEC v. Wis. Right to Life, Inc., 551 U.S. 449 (2007); Randall v. Sorrell, 548 U.S. 230 (2006); Wis. Right to Life, Inc. v. FEC, 546 U.S. 410 (2006).

Knox v. Serv. Employees Int'l Union, Local 1000, 132 S. Ct. 2277 (2012) nominally involved an individual seeking relief from union dues. Mr. Knox's status as a "village Hampden," however, is somewhat diluted by the fact that he was represented by Hogan and Hartson and the National Right to Work Legal Defense Foundation.

66 See Reichle v. Howards, 132 S. Ct. 2088 (2012); Borough of Duryea v. Guarnieri, 131 S. Ct. 2488 (2011); Nev. Comm'n on Ethics v. Carrigan, 131 S. Ct. 2343 (2011); Pleasant Grove City v. Summum, 555 U.S. 460 (2009); Morse v. Frederick, 551 U.S. 393 (2007); Tenn. Secondary Sch. Athletic Ass'n v. Brentwood Acad., 551 U.S. 291 (2007); Beard v. Banks, 548 U.S. 521 (2006); Garcetti v. Ceballos, 547 U.S. 410 (2006); Hartman v. Moore, 547 U.S. 250 (2006); cf. Holder v. Humanitarian Law Project, 130 S. Ct. 2705 (2010); United States v. Williams, 553 U.S. 285 (2008). 


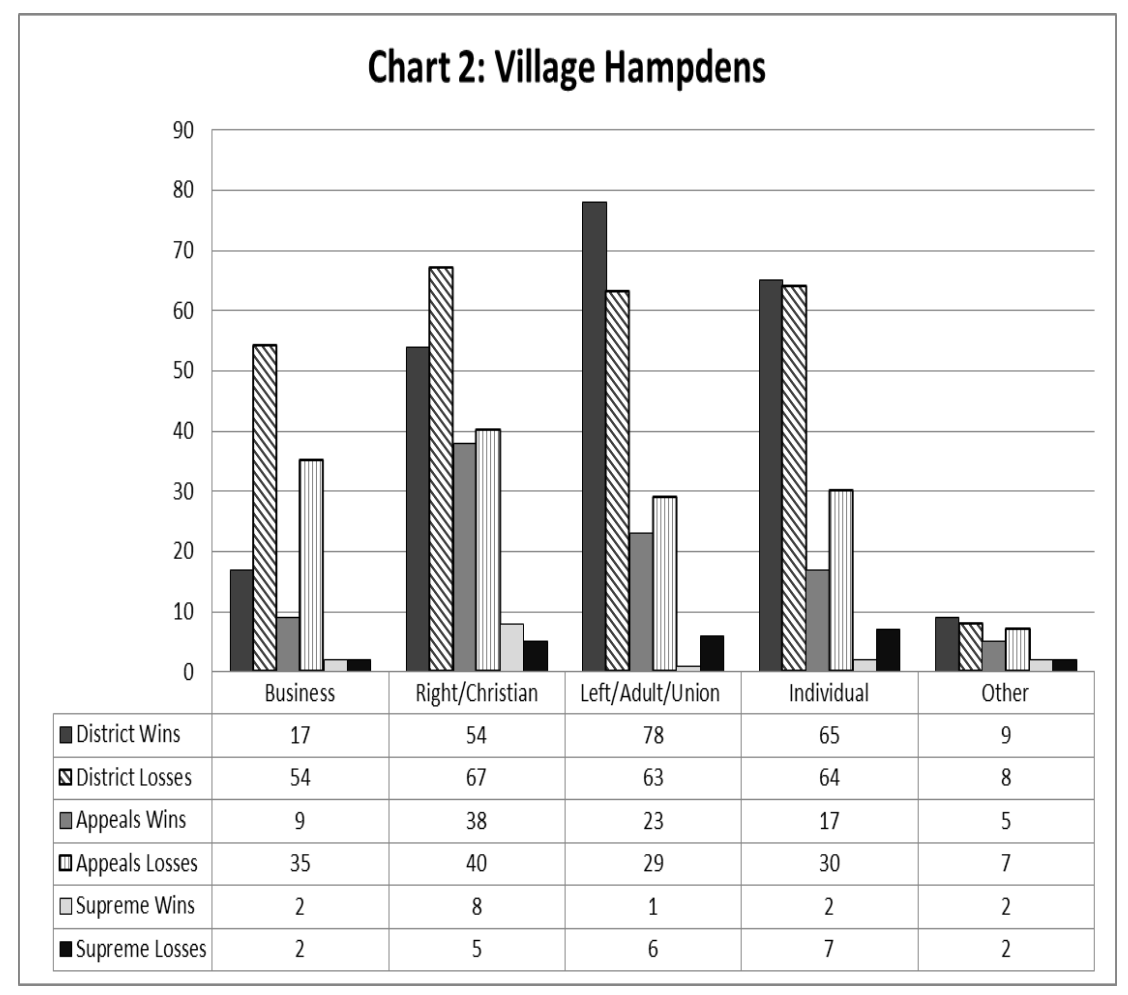

The content neutrality cases in the lower court sample tell a different story.

Mainstream businesses accounted for only $8 \%$ of successful cases in the lower courts sample. Businesses were not infrequent litigants, but unlike in the Supreme Court, where businesses prevailed in 50\% of their appearances, businesses lost four times as often as they won in the lower courts. Large institutional plaintiffs, like political parties, nonprofit institutions, and media companies accounted for an even smaller number of cases and victories than did businesses.

By contrast, in the lower courts, village Hampdens challenging the local status quo predominated, and succeeded regularly. Combined, cases involving idiosyncratic individuals, religious plaintiffs, and local ideological plaintiffs of the Left and Right, accounted for $79 \%$ of the lower court sample and $88 \%$ of successful claimants.

In the lower court samples, idiosyncratic individuals who suffered adverse consequences constituted $18 \%$ of successful litigants in courts of appeals and $29 \%$ of successful litigants in district courts. Individuals won more regularly than businesses at the appeals level-36\% of 
cases-and far more often in the trial courts $(47 \%)$. But individuals still lost most of their cases.

\begin{tabular}{|l|l|l|l|l|l|l|}
\hline Claimant & $\begin{array}{l}\text { District } \\
\text { Totals }\end{array}$ & $\begin{array}{l}\text { District } \\
\text { Wins }\end{array}$ & $\begin{array}{l}\text { District } \\
\text { Losses }\end{array}$ & $\begin{array}{l}\text { Ap- } \\
\text { peals } \\
\text { Totals }\end{array}$ & $\begin{array}{l}\text { Ap- } \\
\text { peals } \\
\text { Wins }\end{array}$ & $\begin{array}{l}\text { Ap- } \\
\text { peals } \\
\text { Losses }\end{array}$ \\
\hline \hline Business & $\begin{array}{l}14.79 \\
\%\end{array}$ & $7.62 \%$ & $\begin{array}{l}21.09 \\
\%\end{array}$ & $18.88 \%$ & $9.78 \%$ & $24.82 \%$ \\
\hline \hline Right & $9.38 \%$ & $8.52 \%$ & $\begin{array}{l}10.16 \\
\%\end{array}$ & $10.30 \%$ & $11.96 \%$ & $9.22 \%$ \\
\hline \hline Christian & $\begin{array}{l}16.04 \\
\%\end{array}$ & $\begin{array}{l}15.70 \\
\%\end{array}$ & $\begin{array}{l}16.02 \\
\%\end{array}$ & $23.18 \%$ & $29.35 \%$ & $19.15 \%$ \\
\hline \hline Union & $1.88 \%$ & $3.59 \%$ & $0.39 \%$ & $1.72 \%$ & $1.09 \%$ & $2.13 \%$ \\
\hline \hline Adult Biz & $6.88 \%$ & $6.73 \%$ & $7.03 \%$ & $6.44 \%$ & $4.35 \%$ & $7.80 \%$ \\
\hline \hline $\begin{array}{l}\text { Left } \\
\text { Renristian }\end{array}$ & $\begin{array}{l}20.63 \\
\text { Religion }\end{array}$ & $\begin{array}{l}24.66 \\
\%\end{array}$ & $\begin{array}{l}17.19 \\
\%\end{array}$ & $14.16 \%$ & $19.57 \%$ & $10.64 \%$ \\
\hline \hline al & $\%$ & $0.90 \%$ & $0.39 \%$ & $0.43 \%$ & $1.09 \%$ & $0.00 \%$ \\
\hline \hline Media & $2.29 \%$ & $2.69 \%$ & $1.95 \%$ & $3.43 \%$ & $2.17 \%$ & $4.26 \%$ \\
\hline
\end{tabular}

Ideologically and religiously motivated dissidents from local orthodoxy of Left and Right were even more prevalent and successful, accounting for $52 \%$ of successful cases in the lower court sample.

Strikingly, in light of the historical image of the First Amendment as a bastion of left-wing enthusiasm, the most numerous successful litigants in the court of appeals were Christians, a category of challeng- 
ers largely absent from the Roberts Court docket. Christian antiabortion protesters, evangelists, and opponents of gay rights accounted for $23 \%$ of all cases and $29 \%$ of prevailing claimants in the courts of appeals. In the district court, the overall incidence of Christian claimants fell to $16 \%$ and a similar proportion of successful claimants.

Ideological right-wing litigants accounted for another $10 \%$ of total and $12 \%$ of prevailing claimants in the courts of appeals, and $9 \%$ of total and $8 \%$ of prevailing claimants in the district courts. Combined, the Christian and right-wing claimants accounted for $41 \%$ of successes in the courts of appeals and $24 \%$ of successes in the district courts.

On the other side of the political spectrum, local plaintiffs of the political left represented $19 \%$ of successes in the courts of appeals and $24 \%$ of the successes in the district courts. Expanding the view to the cultural left, by including litigation by proprietors of adult entertainment establishments and unions, increases the Left's share to $24 \%$ of appeals court successes and $34 \%$ of trial court successes.

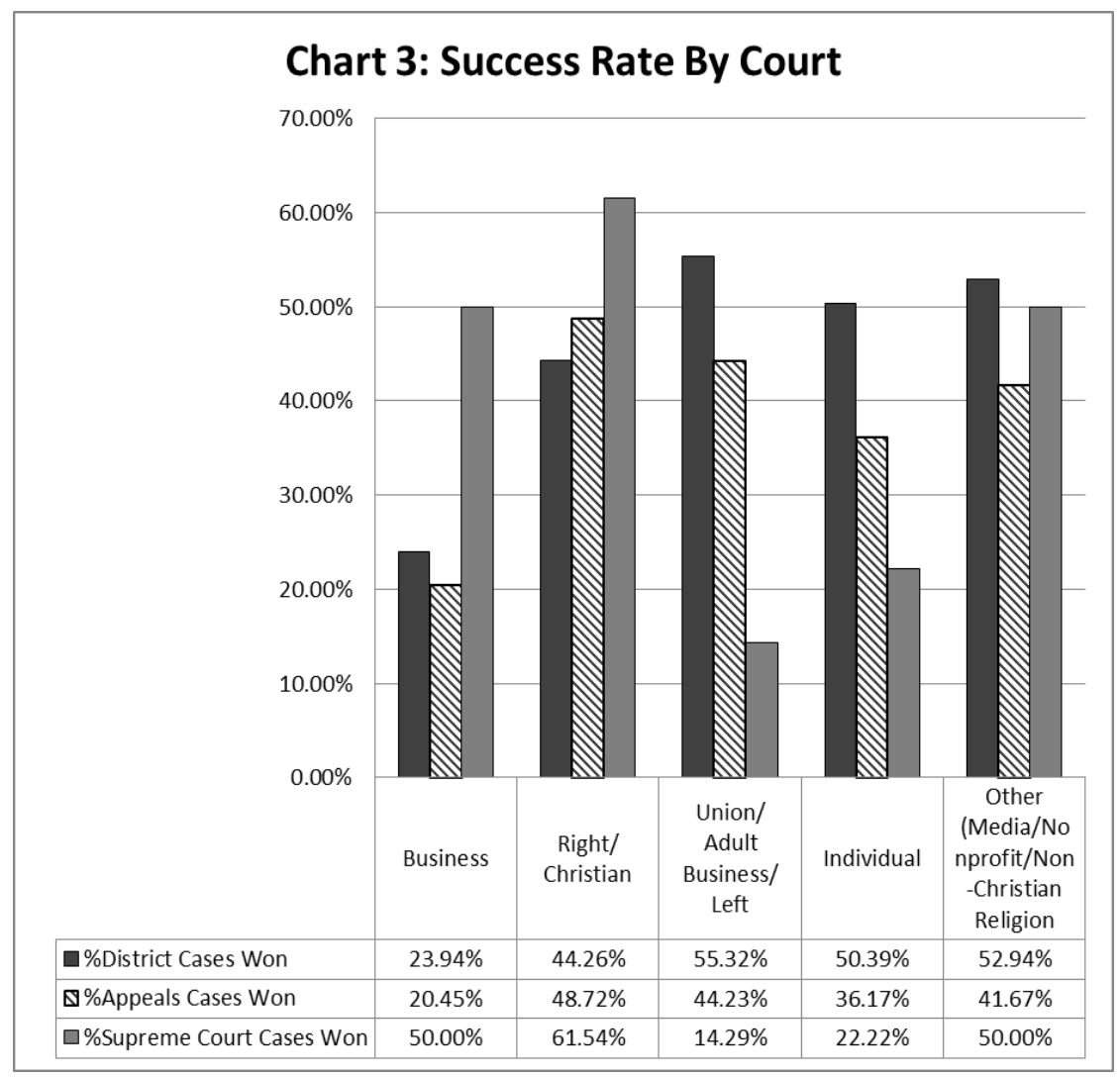


This pattern of successes highlights the distinctiveness and limited perspective of a focus on recent Supreme Court decisions. In the lower courts, unlike in the Supreme Court, business claimants lost the vast majority of their cases. Individuals, who lost four out of five cases in the Supreme Court, prevailed in almost half of their content neutrality cases before the district courts. In the lower courts, ideological plaintiffs roughly break even. District courts litigants from the cultural and political left prevail a bit more often than they lose; in the courts of appeals, they lose slightly more often than they win. For litigants of the cultural and political right, the pattern is reversed. Roberts Court decisions, by contrast, are four times as likely to sustain right-wing claims as claims from the Left.

\section{The Hampdens' Champions}

In the lower courts, village Hampdens often did not struggle alone. While most sampled cases did not report the presence of repeat playing ideological counsel, $31 \%$ of all cases and almost two thirds of cases involving ideological plaintiffs reported representation by movement affiliated or public interest lawyers of the Left or Right. $^{67}$

67 The role of the ACLU in First Amendment cases is a matter of common fame. The development of comparable support structures on the right has not been as widely remarked upon. For recent examinations, see JoshUA C. WiLSON, THE STREet POLITICS OF Abortion: Speech, Violence, AND AmericA's Culture Wars (2013); Amanda HollisBrusky, Support Structures and Constitutional Change: Teles, Southworth, and the Conservative Legal Movement, 36 LAW \& SOC. INQUIRY 516 (2011). 




The presence of ideological counsel is correlated with a substantially higher rate of success in the trial courts for left-wing counsel, and higher rates of success on appeal for both left- and right-wing counsel. From these results, one could infer either that specialized counsel is particularly effective in these forums, or that specialized counsel is better at culling losing cases out of the mix. Likewise, the robust left/right divergence, which is particularly striking at the district court level, could imply better lawyering by left-wing ideological attorneys, less aggressive case selection, or judicial inclination. The fact that the overall rates of success of right and left-wing claimants overall follow a different pattern from the rate of ideologically counseled plaintiffs suggests that the issue is not one of judicial inclination. 


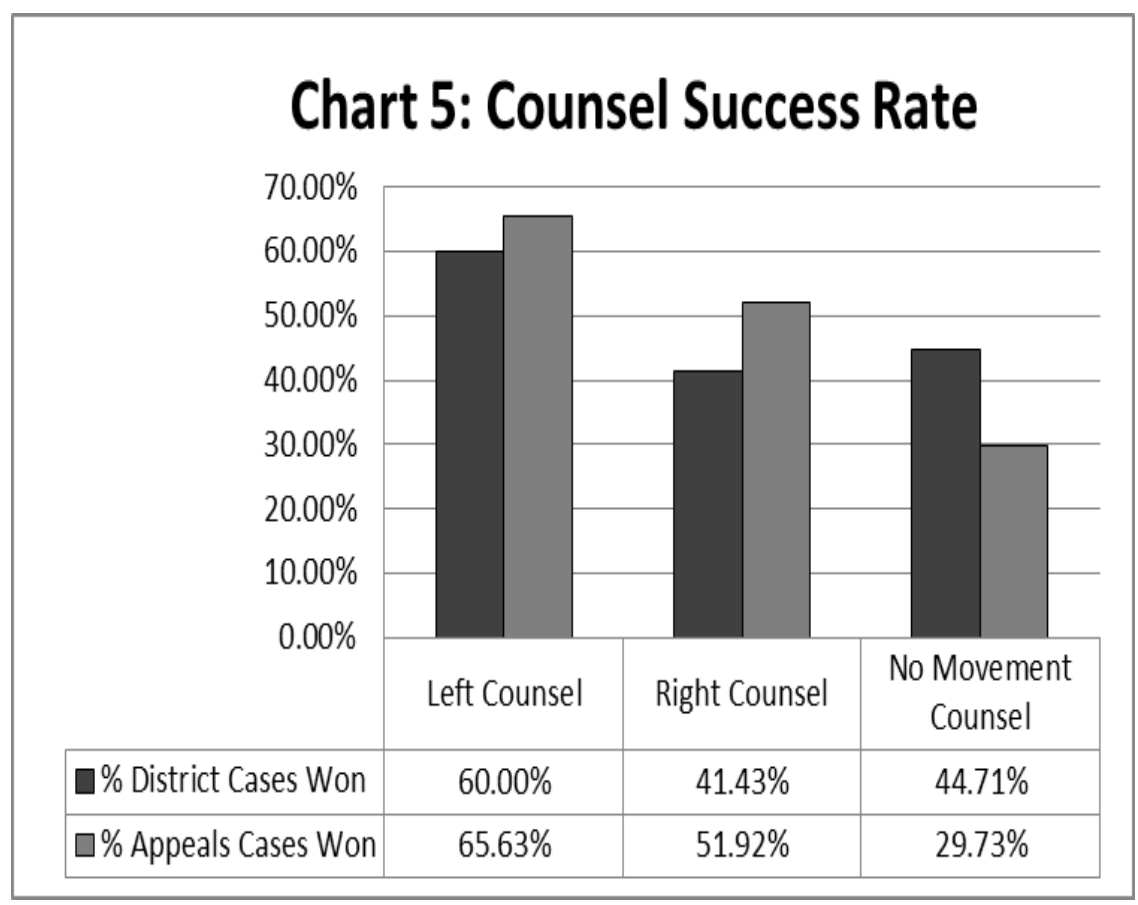

C. Content Neutrality, the Public Forum, and Its Patrons

\section{Against The Doctrine: Content Neutral Wins, Content Based Losses}

The black letter doctrine of the First Amendment is often understood by law students to be: "content neutral good, content based bad." ${ }^{68}$ At the Supreme Court level, the relevant case law echoes with pronouncements that "content-based restrictions on speech have been permitted, as a general matter, only when confined to the few historic and traditional categories [of expression] long familiar to the bar. ${ }^{\circ 9}$

68 Herzog, supra note 29, at 12 ("The alleged black-letter rule is that the state may not regulate speech on the basis of its content.”). For a more credulous account, see Daryl J. Levinson, Rights Essentialism and Remedial Equilibration, 99 COLUM. L. REV. 857, 902 (1999) ("The single most important feature of free speech doctrine is its different treatment of content-based laws, which are usually invalidated unless they fall within one of several exceptional categories... and content-neutral laws, which are almost always upheld."). Cf. GEORGE ORWELL, ANIMAL FARM 43-50 (4th ed. 1990) ("four legs good, two legs bad").

69 United States v. Alvarez, 132 S. Ct. 2537, 2544 (2012) (citing Stevens, 559 U.S. at 468 (quoting Simon \& Schuster, Inc. v. Members of the N.Y. State Crime Victims Bd., 502 U.S. 105, 127 (1991) (Kennedy, J., concurring))) (internal quotation marks omitted). 
Although the Roberts Court regularly reviewed content based restrictions on speech, the outcomes were somewhat more uncertain than these proclamations might suggest. ${ }^{70}$ Of the government actions interfering with free expression reviewed by the Roberts Court, nineteen have been characterized as "content based," of which ten (52\%) have been struck down. Only three restrictions were characterized as "content neutral"; one was found invalid. ${ }^{71}$

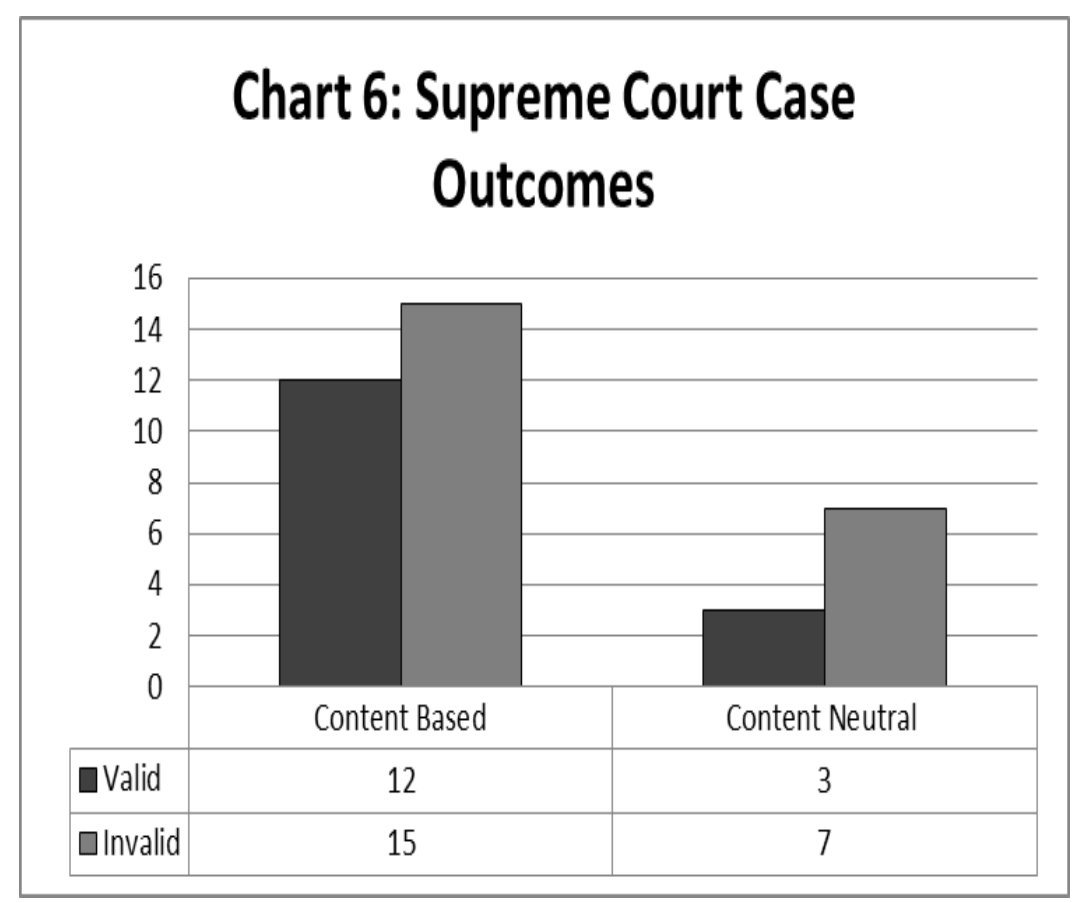

70 A careful reader might find herself wary of these proclamations, even before referring to the outcomes of other cases. Alvarez identifies nine exceptional categories. One of them-"speech integral to criminal conduct"-is anything but clear and confining. Alvarez, 132 S. Ct. at 2544 (2012) (asserting that all nine exceptions "have a historical foundation in the Court's free speech tradition"). Several-technically defined incitement, "true threats", and child pornography—are clearly ahistorical, and have been constructed in the late twentieth century, albeit often for good reasons. Cf. Ronald K.L. Collins, Exceptional Freedom - The Roberts Court, The First Amendment and the New Absolutism, 76 ALB. L. REv. 409, 417-22 (2013) (listing forty-eight different varieties of speech that have been held to be unprotected).

71 See Appendix I. Characterizing the cases in which the Court does not mention content neutrality, among the eight cases involving content based restrictions, two were invalidated; among seven cases involving content neutral restrictions, two were invalidated. See Appendix II. 
In the lower court samples, government burdens characterized as content based also predominate, though not quite so lopsidedly.

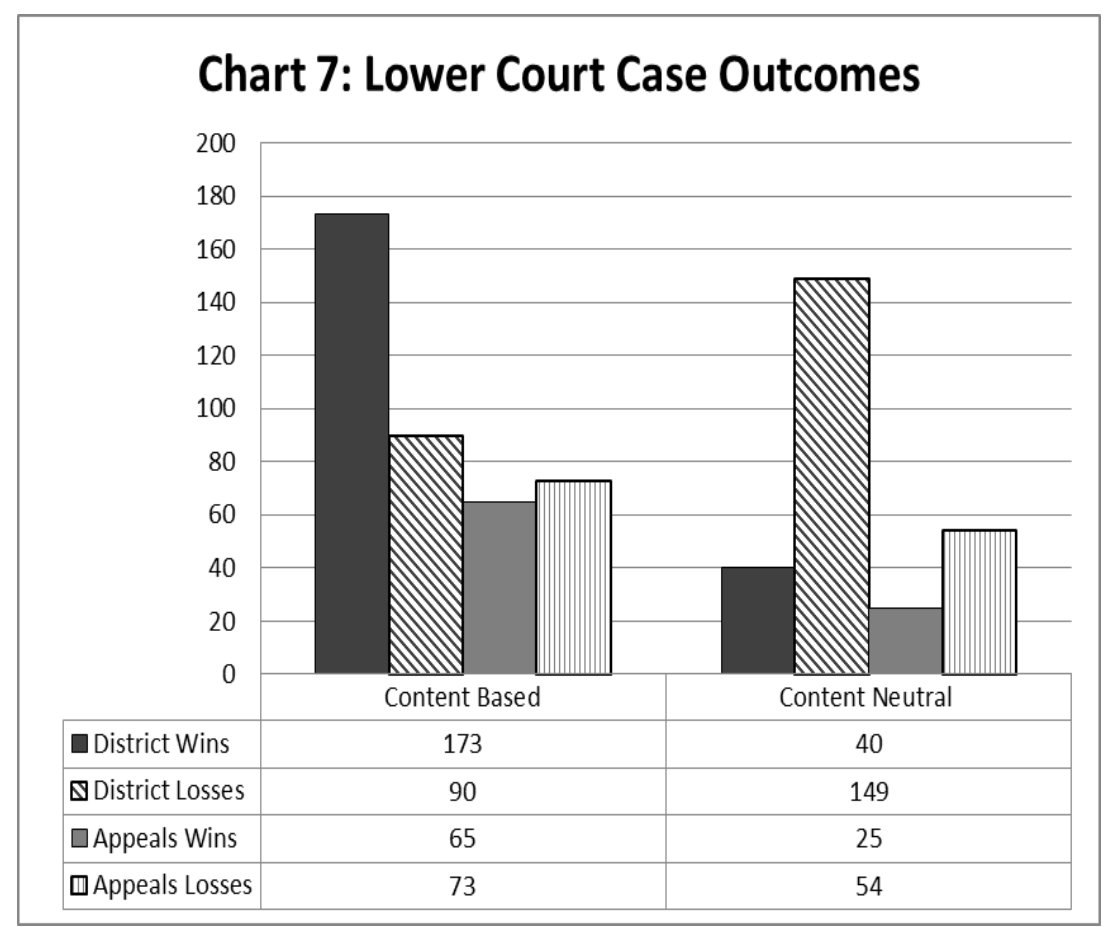

The outcomes conformed somewhat more closely to alleged horn book law in the district courts. Litigants challenging content based restrictions prevailed in the district court in $65 \%$ of cases; content neutral plaintiffs prevailed in only $21 \%$. Claimants failed to overturn content based restrictions either because the restrictions fell within the "few" exceptions to presumptive invalidity, or because the courts concluded that the restrictions were justified under strict scrutiny. At the court of appeals level, like at the Supreme Court level, challengers to content based restrictions were not predominantly successful, prevailing in less than half of the cases; content neutral restrictions were invalidated in almost a third of cases.

Challenges to content neutral restrictions are substantially less likely to succeed than cases against content based restrictions. But in the lower courts, in contrast to commentary, ${ }^{72}$ distinctions deter-

72 E.g., Kendrick, supra note 2, at 237 ("Content-based laws receive strict scrutiny, which nearly always proves fatal. Meanwhile, content-neutral laws receive what the Court calls 'intermediate scrutiny,' in practice a highly deferential form of review which virtually all laws pass."). 
mined to be content neutral do not get a free pass. Consistent with Supreme Court doctrine, though not always Supreme Court practice, lower courts evaluate with some seriousness whether the content neutral restriction vests officials with unbridled discretion, leaves adequate alternative opportunities for communication, or imposes unjustified or unreasonable, though content neutral burdens. The government cannot deploy content neutral restrictions indiscriminately. ${ }^{73}$ Indeed, as we will see, in public forum cases before the courts of appeals, plaintiffs prevailed in the majority of cases.

\section{Public Forum, Limited Public Forum, Direct Regulation}

Content discrimination does robustly determine outcomes in a subset of cases. It is important, as it turns out, to disentangle cases involving public forums, limited public forums, and cases involving direct regulation of primary expressive activity. Recall that the content neutrality doctrine took root in cases dealing with the problem of the public forum. While municipalities were entitled to administer streets and parks and to impose "time, place, and manner" restrictions on expression in them, regulations were acceptable only as long as they were "content neutral." Public forum and limited public forum cases, almost absent from the docket of the Roberts Court, made up the second and third most frequent content neutrality cases before the lower courts.

Although only one per curiam public forum case has appeared at the Supreme Court level in the Roberts Court, ${ }^{74}$ this heartland of content neutrality remains a fruitful source of First Amendment claims in the lower courts.

73 Indeed, on an impressionistic reading of these cases, the bulk of restrictions upheld (including noise ordinances, junk prohibitions, prohibitions of sleeping in parks, etc.) strike me, as an ACLU board member, as quite sensibly decided.

74 Lefemine v. Wideman, 133 S. Ct. 9 (2012). 




In public forum cases, a finding of "content discrimination" is as fatal in the lower courts as the hornbook law would suggest. In $97 \%$ of district court cases and $87 \%$ of court of appeals cases, a determination of content discrimination resulted in invalidation. On the other hand, content neutrality is no guarantor of constitutional viability. In public forum cases involving neutral regulations, claimant success rates were $28 \%$ in the district court and $56 \%$ in the court of appeals. 

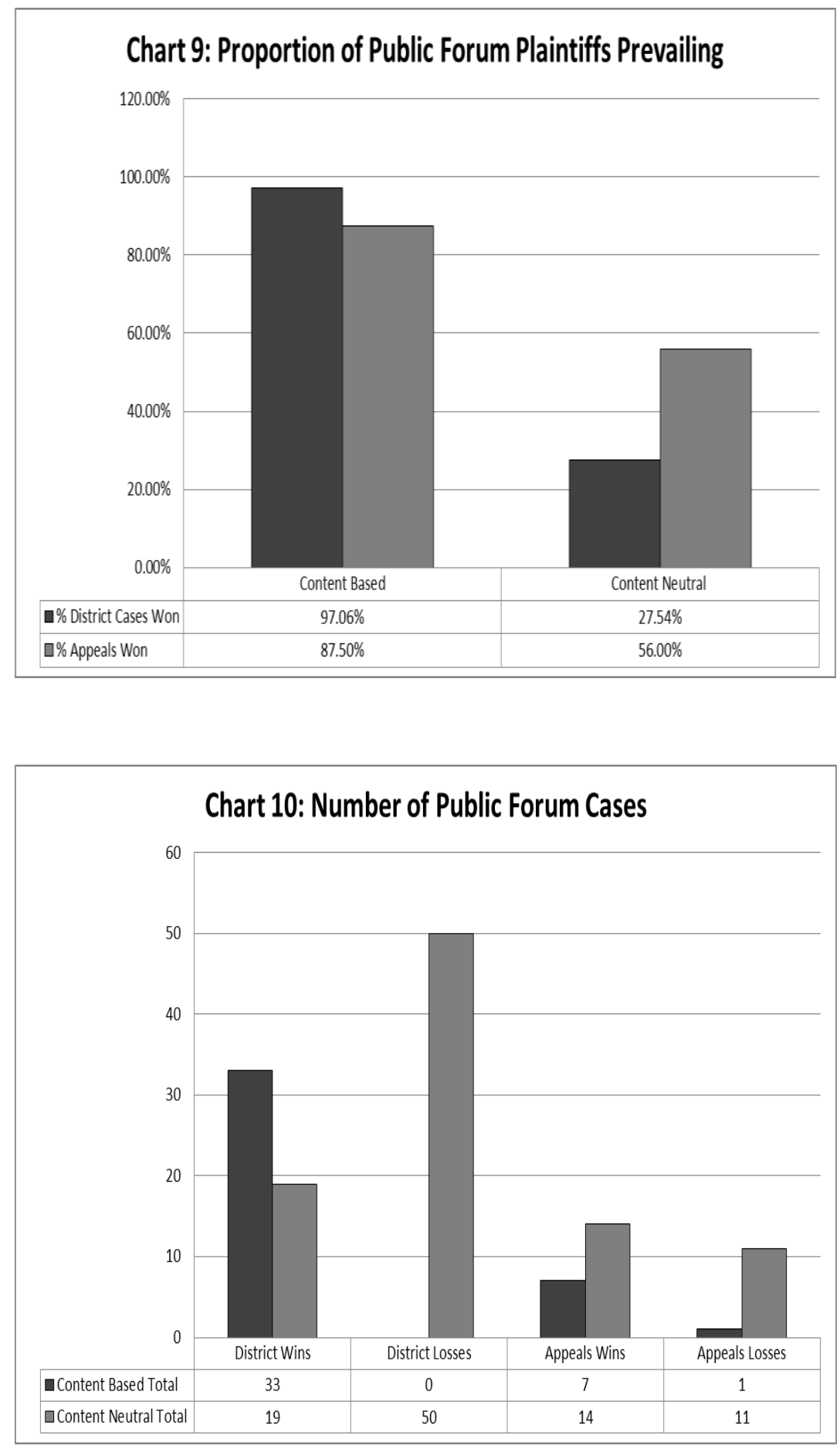
In limited public forum cases, viewpoint discrimination was invariably fatal, while viewpoint neutral regulations almost invariably survived challenge.
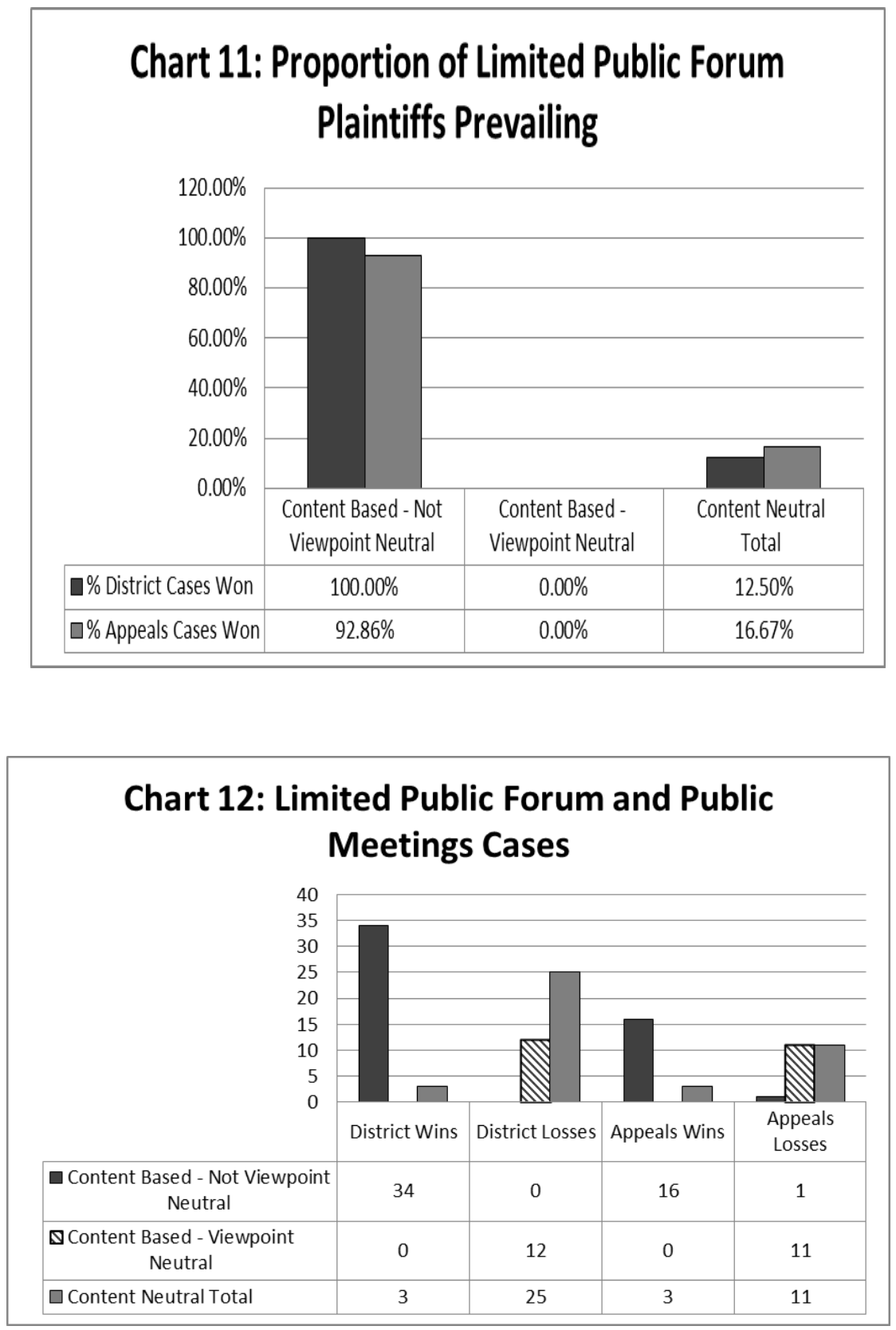

By contrast, in direct regulation cases overall, $59 \%$ of content discriminatory burdens were invalidated. Invalidation rates ran even 
lower in school (42\%), commercial speech $(31 \%)$, and government speech cases $(17 \%)$. Direct regulation claimants succeeded against content neutral regulations in almost a quarter of cases.

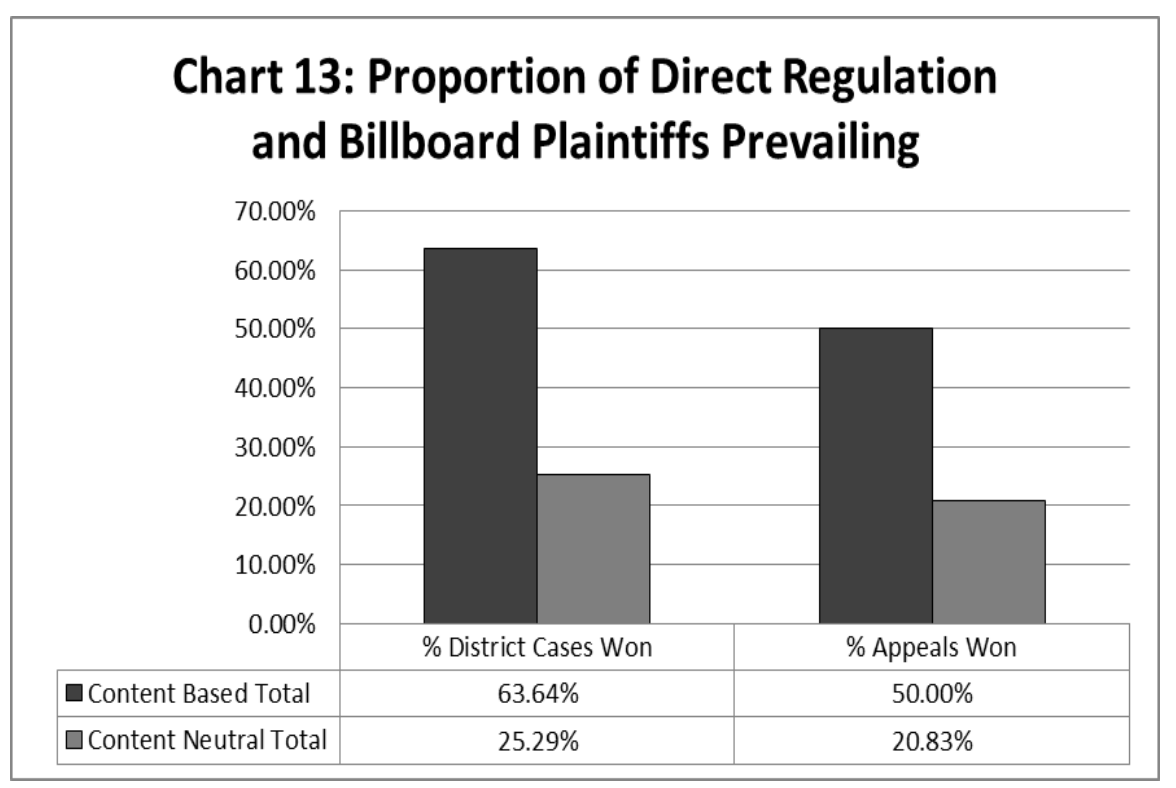

\section{Chart 14: Direct Regulation (and Billboard) Cases}

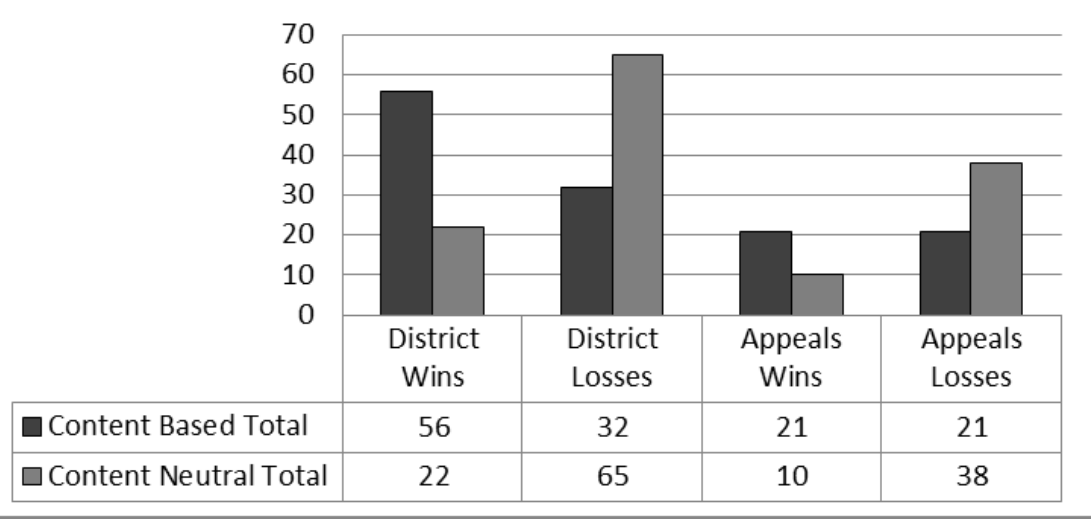

\section{Weak and Strong Content Neutrality}

As noted above, Supreme Court opinions leave considerable room for debate regarding whether content neutrality is to be judged on 
the stronger conjunctive basis of the nature of the operative decision rule and the government's justification, or the weaker investigation "principally" into the motivation of government decision makers and whether "censorship is afoot." In the bulk of the cases where content neutrality was at issue, the classification of the restriction was not a subject of debate. The differences between strong and weak interpretations were at issue in $9 \%$ of district court cases and $14 \%$ of cases in the courts of appeals. District courts divided evenly between strong and weak definitions where the issue arose, while courts of appeals skewed toward weak interpretations.

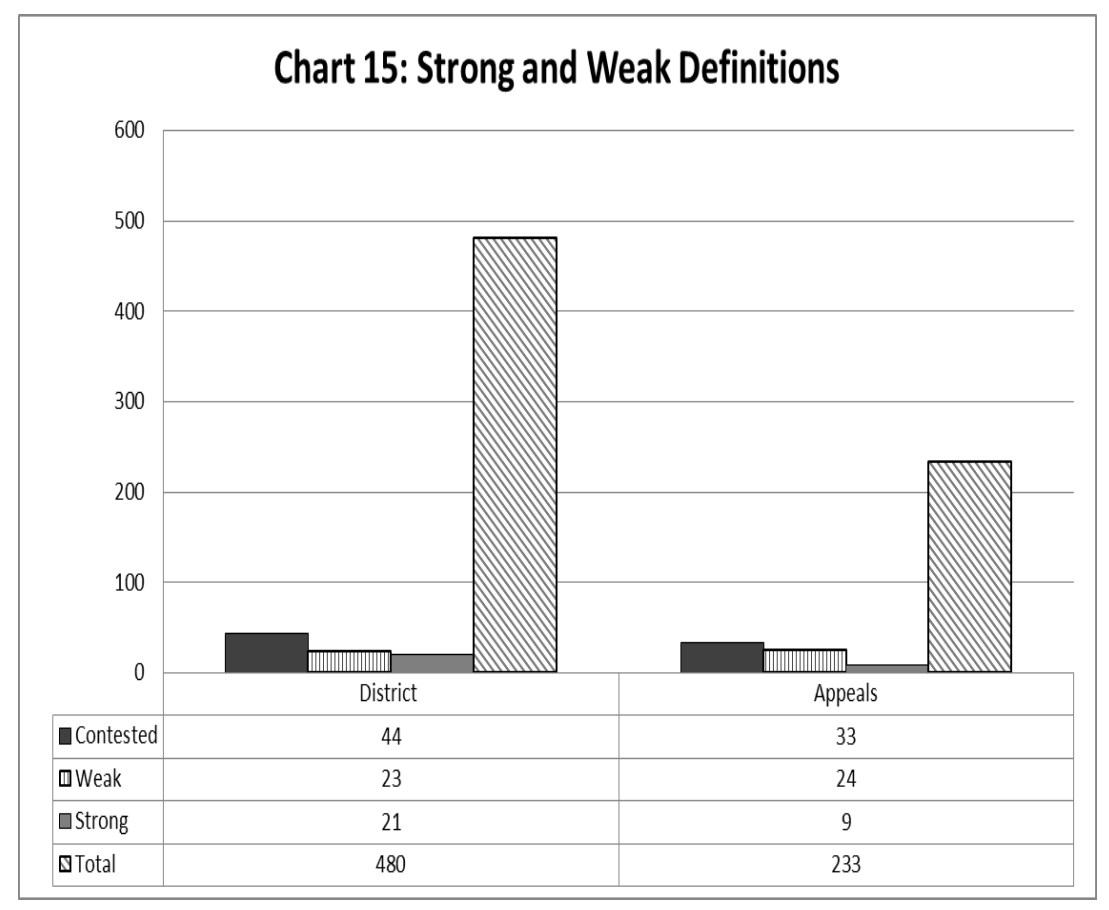

An array of Justices acknowledge that the "secondary effects" doctrine deployed to characterize zoning and licensing restrictions of sexualized speech in adult entertainment venues as "content neutral" is a bit of a cheat. ${ }^{76}$ In the smaller sample of thirty-three cases chal-

See supra notes 20-24 and accompanying text.

76 City of L.A. v. Alameda Books, Inc., 535 U.S. 425, 457 (2002) (Souter, J., dissenting) (joined by Justices Stevens and Ginsburg); id. at 448 (Kennedy, J., concurring in judgment); cf. City of Littleton v. Z.J. Gifts D-4, L.L.C., 541 U.S. 774, 787 (2004) (Souter, J., concurring in part and concurring in judgment) (joined by Justice Kennedy); FW/PBS, 
lenging "content neutral" restrictions on adult oriented expression, plaintiffs succeeded more than twice as often as true content neutral challengers in the trial courts, while at the appellate level, they were half as successful.

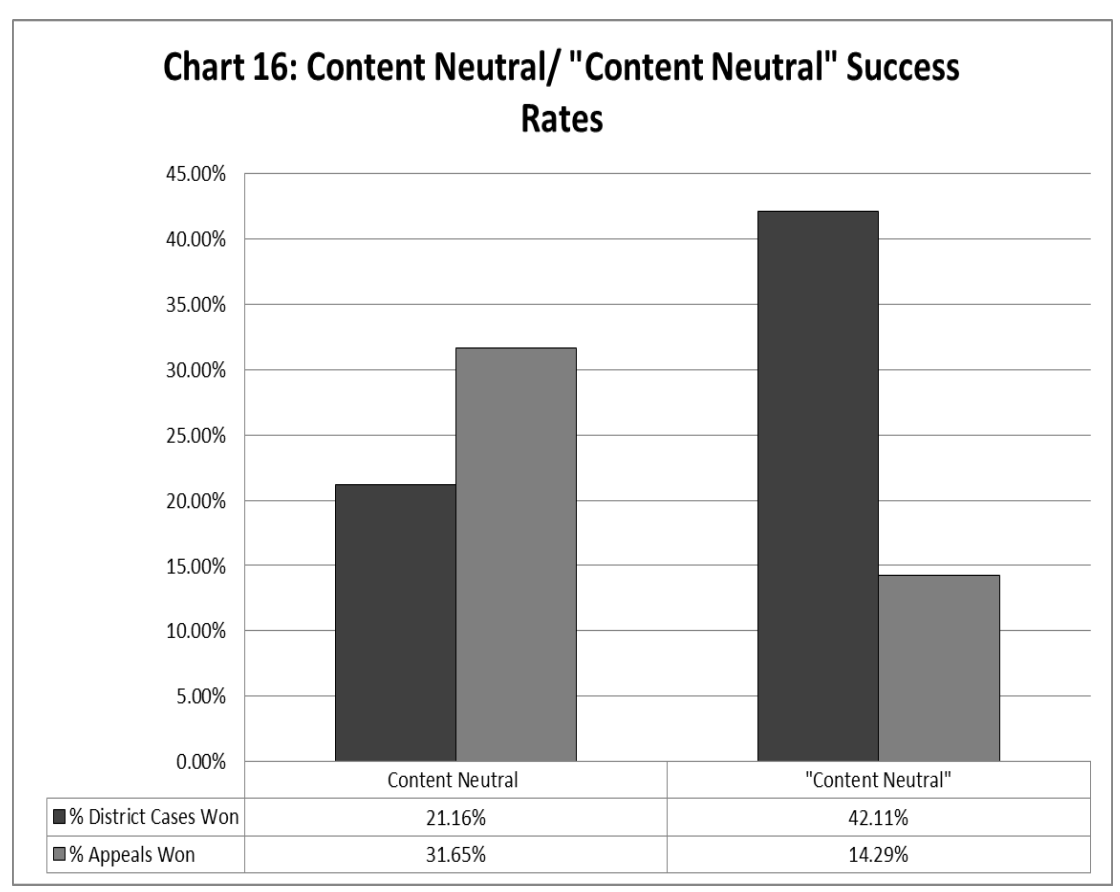

\section{The Venues and Patrons of Content Neutrality}

Public forum and limited public forum cases in the lower court sample were almost exclusively contests between village Hampdens and village tyrants. A vast preponderance of the village Hampdens in public forum litigation were either Christian activists or left-wing activists

Inc. v. City of Dall., 493 U.S. 215, 253 (1990) (Scalia, J., concurring) ("It does not seem to me desirable to perpetuate such a regime of prohibition by indirection."). 




Successful claimants in public forum cases included anti-abortion protestors disturbing the local populace in Oakland, South Carolina, and Maryland, ${ }^{77}$ Christian evangelists seeking to reform the patrons of a gay pride event in Minneapolis and win converts at the Salmon Festival in Issaquah, Washington; ${ }^{78}$ street preachers in Santa Cruz; ${ }^{79}$ and Indiana Christian demonstrators "who targeted the French Lick Resort Casino ... for its involvement in 'gambling, sodomy, abortion, weak-kneed Baptists and other various and sundry sins." $\$ 0$

77 Hoye v. City of Oakland, No. C 07-06411, 2012 U.S. Dist. LEXIS 142038 (N.D. Cal. Oct. 1, 2012); Swagler v. Sheridan, 837 F. Supp. 2d 509 (D. Md. 2011); Lefemine v. Davis, 732 F. Supp. 2d 614 (D.S.C. 2010) aff'd sub nom. Lefemine v. Wideman, 672 F. 3d 292 (4th Cir 2012) cert. granted, judgment vacated, 133 S. Ct. 9 (2012).

78 Ascherl v. City of Issaquah, No. C11-1298, 2011 U.S. Dist. LEXIS 108475 (W.D. Wash. Sept. 21, 2011); Gay-Lesbian-Bisexual-Transgender Pride/Twin Cities v. Minn. Park \& Rec. Bd., 721 F. Supp. 2d 866 (D. Minn. 2010).

79 Hampsmire v. City of Santa Cruz, 899 F. Supp. 2d 922 (N.D. Cal. 2012).

80 Lewis v. McCracken, 782 F. Supp. 2d 702, 705 (S.D. Ind. 2011) (internal citation omitted). 
They encompassed, as well, day laborers in Redondo Beach $;^{81}$ antiwar demonstrators in Michigan, Tacoma, and Olympia; ${ }^{82}$ Occupy Boise, Occupy Columbia, and Occupy Fresno; ${ }^{83}$ free thinkers in Arkansas; ${ }^{84}$ Tea Party enthusiasts in New Jersey; ${ }^{85}$ anti-tax protestors in Cincinnati ${ }^{86}$ Palestinian sympathizers who sought to confront the Ulster County Jewish Federation; ${ }^{87}$ and animal rights protestors alleged to be "obstructing the positive feeling" of the "Red Nose Run" in Hartford, Connecticut. ${ }^{88}$

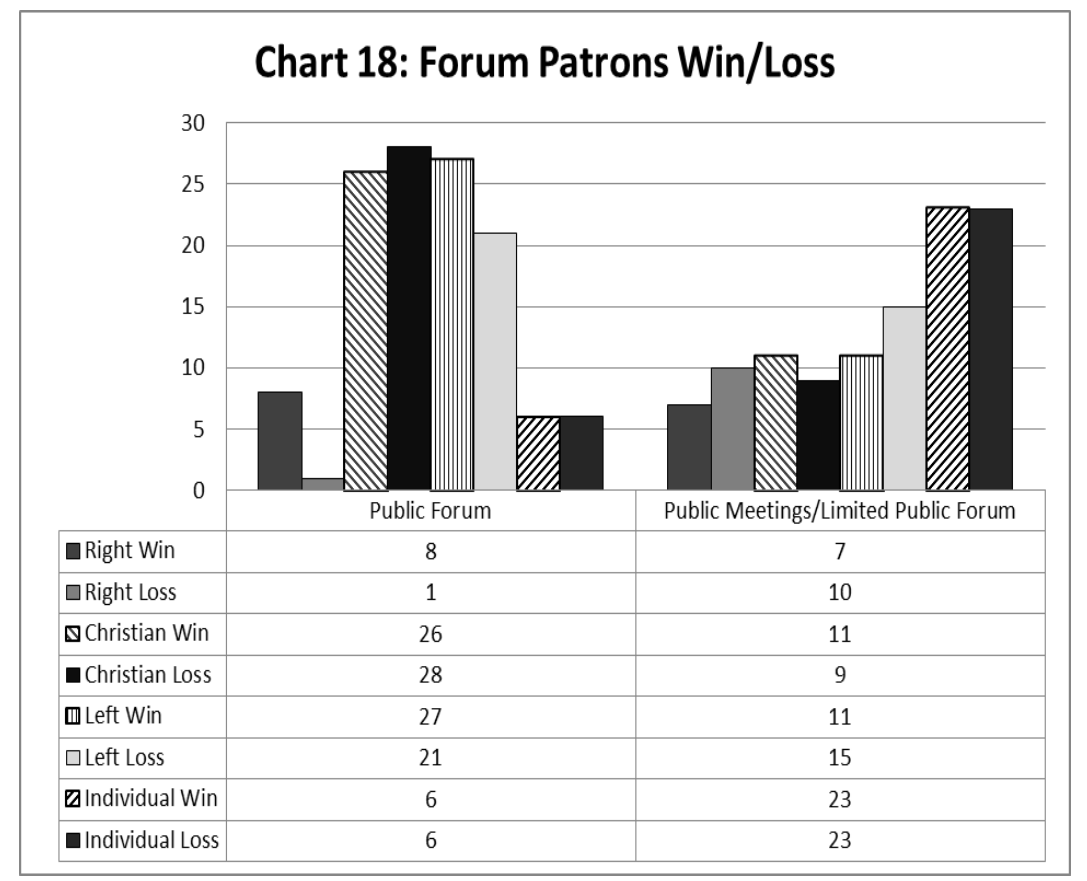

81 Comite De Jornaleros De Redondo Beach v. City of Redondo Beach, 657 F.3d 936 (9th Cir. 2011) (en banc).

82 Lowden v. Clare Cnty., No. 1:09-cv-11209, 2011 U.S. Dist. LEXIS 101200 (E.D. Mich. Sept. 8, 2011); McCarthy v. Barrett, 804 F. Supp. 2d 1126 (W.D. Wash. 2011); Hamilton v. City of Olympia, 687 F. Supp. 2d 1231 (W.D. Wash. 2009).

83 Occupy Columbia v. Haley, 922 F. Supp. 2d 524 (D.S.C. Feb. 7, 2013) aff'd, 738 F.3d 107 (4th Cir. 2013); Watters v. Otter, 854 F. Supp. 2d 823 (D. Idaho 2012); Occupy Fresno v. Cnty. of Fresno, 835 F. Supp. 2d 849 (E.D. Cal. 2011).

84 Ark. Soc'y of Freethinkers v. Daniels, No. 4:09CV00925, 2009 U.S. Dist. LEXIS 116982 (E.D. Ark. Dec. 16, 2009).

85 Liberty \& Prosperity 1776, Inc. v. Corzine, 720 F. Supp. 2d 622 (D.N.J. 2010).

86 Miller v. City of Cin., 622 F.3d 524 (6th Cir. 2010).

87 Middle E. Crisis Response v. City of Kingston, No. 1:08-CV-0690, 2010 U.S. Dist. LEXIS 90637 (N.D.N.Y. Sept. 1, 2010).

88 Zalaski v. City of Hartford, 704 F. Supp. 2d 159, 164 (D. Conn. 2010). See Cuviello v. City of Oakland, No. C 06-5517, 2009 U.S. Dist. LEXIS 102491 (N.D. Cal. Nov. 3, 2009). 
In limited public forum cases, unaffiliated individuals loom larger, joined in smaller numbers by Christians, and activists of both Left and Right. ${ }^{89}$

In direct regulation cases, by contrast, businesses emerge as substantial litigants (33\%), along with adult businesses (16\%) and individuals (24\%). Twenty-three percent of businesses' challenges, 38\% of challenges by adult businesses, and $46 \%$ of challenges by individuals succeed.

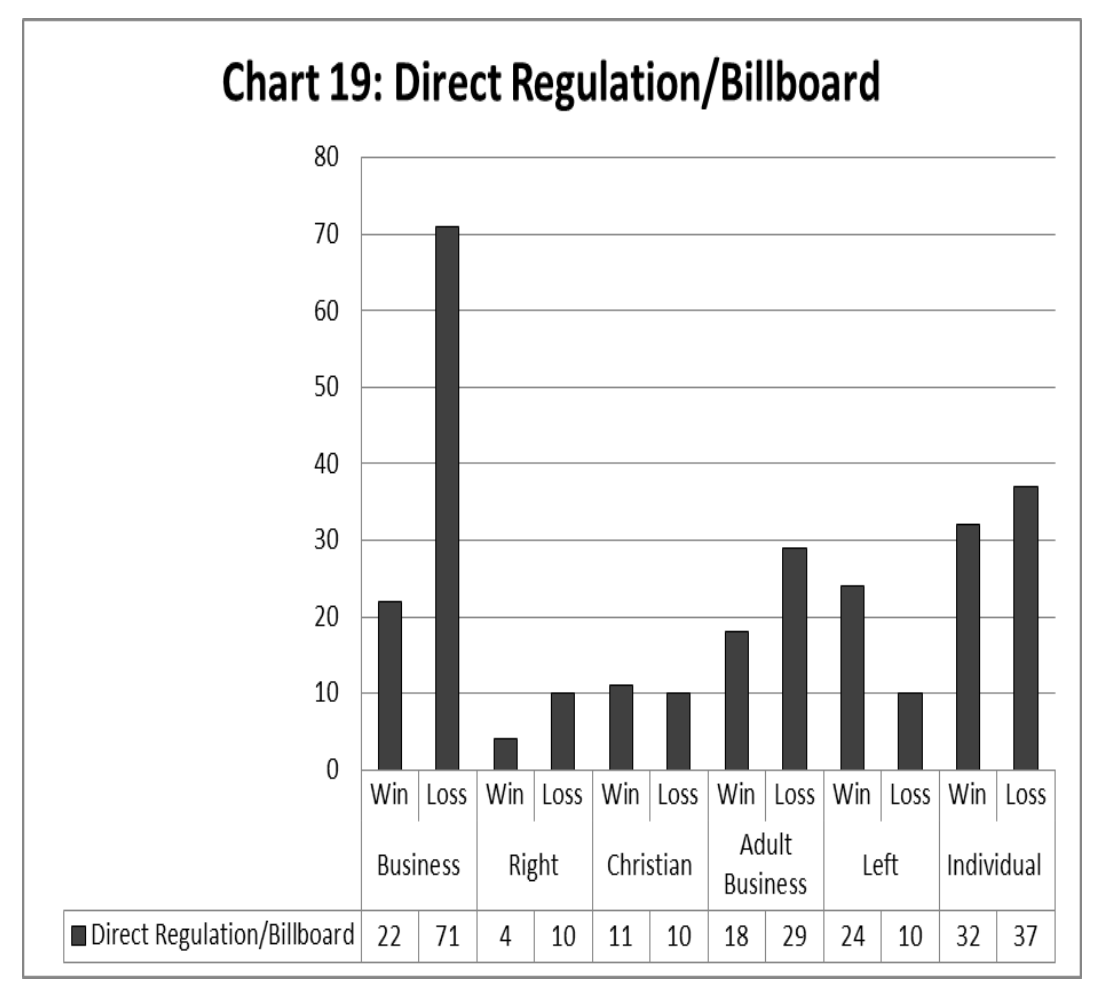

\section{III. “THE SPIRIT OF GOVERNMENT": ROBUST FREE SPEECH IN A DECENTRALIZED FEDERAL SYSTEM}

As it turns out, when we examine content neutrality cases in the lower courts, we discover that most cases involve face-offs between potential village tyrants and village Hampdens. And First Amendment

89 The bulk of individuals seeking to use limited public forums (twenty-nine out of forty-six) were individuals barred from speaking at local city council, school board, or town meetings. 
claimants most often succeed in challenging local officials who administer public or limited public forums.

Is it reasonable to believe that local officials who bar animal rights protestors from the Red Nose Run, or Christians from evangelizing patrons of the French Lick Casino are motivated by plausible and honest concerns for tranquility rather than hostility to vegans or Christian evangelists? Absolutely. Do these decisions substantially mutilate the nation's capacity for self governance or threaten to drive ideas from the national dialog? It seems unlikely. Yet acts of local censorship affront autonomy of the intellect. More importantly, they corrode commitments to openness and tolerance on the part of governors and the governed that underpin America's system of free expression.

Practices of local tolerance that acknowledge space for village Hampdens, by contrast, provide concrete and visible training in the norms of a free people. The confrontation between village tyrants and village Hampdens is the field on which habits of public morality are formed; it is here that content neutrality finds substantial grounds for its defense.

This insight underlay the genesis of content neutrality as a doctrinal device. ${ }^{90}$ Content neutrality need be defended neither as a means of purging censorial motivation nor as a doctrine that directly prevents government interventions that warp public discourse. In its strong form, the doctrine functions to minimize interferences with free speech that reflect and establish pernicious habits of censorship and silence. As Justice Brennan, who laid the cornerstones of the doctrine, observed,

Our cases since New York Times Co. v. Sullivan have proceeded from the general premise that all libel law implicates First Amendment values... [like other] state efforts to... pursue...public welfare goals through content-based regulation of speech. When we deal with the complex of strands in the web of freedoms which make up free speech, the operation and effect of the method by which speech is sought to be restrained must be subjected to close analysis and critical judgment in the light of the particular circumstances to which it is applied. This general proscription against unnecessarily broad content-based regulation permeates First Amendment jurisprudence. ${ }^{91}$

90 Police Dep't of City of Chicago v. Mosley, 408 U.S. 92, 96 (1972) (quoting N.Y. Times Co. v. Sullivan, 376 U.S. 254, 270 (1964)) ("Any restriction on expressive activity because of its content would completely undercut the "profound national commitment to the principle that debate on public issues should be uninhibited, robust, and wide-open.'”).

91 Dun \& Bradstreet, Inc. v. Greenmoss Builders, Inc., 472 U.S. 749, 778-79 (1985) (Brennan, J., dissenting) (internal citations and quotation marks omitted). 


\section{A. Perspectives on Getting It Right}

\section{The View from the Supreme Court}

One strand of scholarly analysis of constitutional doctrine inquires whether the doctrine impels the Supreme Court to reach proper results with appropriate regularity-and sometimes whether these outcomes can effectively guide legislators in abiding by constitutional limits. Arguments about the propriety of the content neutrality doctrine have often taken this form. ${ }^{92}$ From this vantage, it is not entirely implausible to argue as a first order optimum that alternatives to strong-form content neutrality in the Supreme Court will result in more accurate adjudication.

Perhaps, as Justice Breyer maintains, courts should ignore content neutrality and directly address whether the incremental harm to free speech is "proportionate" to the legitimate governmental interests at stake. $^{93}$ In Supreme Court arguments about cost and benefit, each side has the opportunity to advance relevant information and arguments. Argument before the Court usually takes place in a relatively calm and nominally nonpartisan arena, with the shadow of the future imposed by stare decisis. An all-things-considered decision by the Court may appropriately balance the public and private costs of speech restrictions against their benefits. ${ }^{94}$ Proportionality decisions by the Court might guide the consideration of policies adopted by Congress or responsible federal agencies. Such agencies often have

92 E.g., Stone, Content Regulation and the First Amendment, supra note 6; Stone, Fora Americana: Speech in Public Places, supra note 6; Stone, Restrictions of Speech Because of its Content: The Peculiar Case of Subject-Matter Restrictions, supra note 6; Tushnet, supra note 26; Kagan, Private Speech, Public Purpose, supra note 1; Kagan, Regulation of Hate Speech and Pornography After R.A.V., supra note 1.

93 See supra notes 17-18 and accompanying text.

94 For an argument to this effect, critiquing the recent spate of results that are "counterintuitive ... from the perspective of almost any foundational theory of the First Amendment[,]" see Tushnet, supra note 26, at 8, 23-26 (arguing that the Court should adopt rules that mimic its own "all-things-considered" judgments in particular cases, or, in the alternative, a direct "proportionality" requirement).

There are reasons to suspect that even the judgment of Supreme Court Justices may be tainted by political proclivities. E.g., Lee Epstein et al., Do Justices Defend the Speech They Hate? In-Group Bias, Opportunism, and the First Amendment, ANNUAL MEETING PAPER (Am. Political Sci. Ass'n), at 2-3, 10-11 available at http://papers.ssrn.com/sol3/papers.cfm? abstract_id=2300572 (finding that in over 516 cases and 4519 votes between 1953 and 2010, "the justices' votes tend[ed] to reflect their preferences toward the expresser (or expression)"; liberal justices predictably reduced their probabilities of libertarian votes toward conservative expression from over $90 \%$ to roughly $50 \%$ and conservative justices tended to increase their probabilities of libertarian votes from under $20 \%$ to almost $50 \%$ in the case of conservative expression). 
opportunity for reflective analysis, apply the decisions to the nation as a whole, and are subject to quick prospective judicial review.

As an alternative, in line with weak content neutrality cases and Justice Stevens' focus on motivational neutrality, perhaps the Court should endeavor to discern whether "censorship is afoot" in contested circumstances. It is possible-though not entirely persuasive-to imagine the Supreme Court carefully and accurately discerning whether the motivation for official actions is rooted in illegitimate efforts to suppress expression. And, guided by the Supreme Court, one could believe that Congress and responsible state and federal agencies will carefully examine their own motives and implement a commitment to neutrality by foreswearing regulations that interfere with expression on the basis of "official suppression of ideas."

\section{The View from the Lower Courts and the Firing Line}

But, as we have seen, the Supreme Court is not the field on which content neutrality doctrine is most often deployed, and broadly responsible state and federal legislators are not the decision makers it most often guides. Notwithstanding the view from the Supreme Court's docket, most content neutrality cases involve aspiring village Hampdens and potential village tyrants. The decisions at issue are made by local officials and street level bureaucrats, often acting under pressure of time and circumstance. They choose in settings where the identity of the protagonists is clear. Few disputes regarding their decisions will reach the Supreme Court, and most will not reach court at all.

Constitutional doctrine should give citizens and rulers robust guidance in the areas where it most often applies. It should allow citizens to know enough to invoke their rights successfully without seeking adjudication in every case. A doctrine-particularly a doctrine that will be applied by potential village tyrants-should be easily understood by the officials charged with administering it and should lead them fairly reliably to decisions that are consistent with constitutional commitments to free expression. ${ }^{96}$ Better still, it should pro-

95 Davenport v. Wash. Educ. Ass'n, 551 U.S. 177, 189 (2007).

96 This is not a new desideratum. E.g., Hans A. Linde, "Clear and Present Danger" Reexamined: Dissonance in the Brandenburg Concerto, 22 STAN. L. REv. 1163 (1970); Frederick Schauer, The Second-Best First Amendment, 31 WM. \& MARY L. REv. 1, 15-16 (1989) ("[I]f we think of the full range of governmental officials, including members of a town council deciding whether certain bookstores should be restricted, police officers deciding whether to arrest someone whose criticism of government policy includes strong language [and] a city clerk deciding whether to issue a parade or rally permit to members of a local communist 
vide decision makers a motive to adopt standard operating procedures that preserve opportunities for free speech. And in an increasingly bureaucratized and massive federal system, it should also give law clerks ways to sort cases effectively into categories in which judicial protection for expression is most salient and those in which it is least needed. ${ }^{97}$

As I demonstrate below, strong content neutrality fulfills these functions in a way that its competitors do not. In America, power devolves often to the hands of potential village tyrants, and doctrine enjoining officials to balance costs and benefits of expression becomes a gateway to repression. Political observation and political psychology predict that local officials and street level bureaucrats will suppress speech excessively when asked to suppress it proportionately. A doctrine that mandates that officials act without censorial motives fares not much better, for officials are often blind to their own motivations, adept at rationalization, and eager to avoid offense to majority constituents even when they harbor no malice themselves. By contrast, in the confrontation between village tyrant and village Hampdens, a strong doctrine requiring content neutrality has real virtues in the real world.

\section{B. The Politics and Heuristics of Village Tolerance and Tyranny}

\section{Why We Cannot Trust Proportionality Inquiries to Induce Potential Village Tyrants to Properly Protect Free Expression}

Opinion polling regularly finds that overwhelming majorities of lay Americans, like American community leaders, affirm belief in free speech. But survey research supports what common sense indicated

organization [,] ... we wonder about entrusting to this array of officials the responsibility for making particularistic, case-sensitive determinations regarding what forms of activity will promote the search for truth and what forms will not, what conduct is consistent with democratic theory and what is not, and which acts are self-realizing and which acts are not.").

Then-Professor Kagan observed in her seminal article that "[o]dd as it may seem, it may be easier for legislators to follow rules relating to the terms of a law than to follow a command not to consider illicit factors." Kagan, Private Speech, Public Purpose, supra note 1 , at 441 n.81.

97 A quarter century ago, Vince Blasi argued insightfully that the American polity is subject to periodic outbreaks of popular intolerance, and that First Amendment doctrine has been and should be crafted to protect speech in such periods. Vincent Blasi, The Pathological Perspective and the First Amendment, 85 COLuM. L. REV. 449, 459 (1985). Blasi went on to note the prevalence of local pathologies, and observed " $[\mathrm{m}]$ ost local pathologies must be combatted by district and circuit judges who have closer ties to the political communities that are gripped by pathological anxieties ...." Id. at 510 . 
to Justice Jackson in Barnette. intolerance is likely to characterize official treatment of locally unpopular groups. Polls find that when asked about applying free speech principles in particular cases, large proportions of opinion leaders and majorities of the rank and file are disinclined to allow the specific groups whose messages they find repellant to speak, print, broadcast, or demonstrate.

At the height of the McCarthy era, in 1954, a large sample survey by Samuel Stouffer provided an early landmark. ${ }^{98}$ It found virtually unanimous support for freedom of speech in the abstract both among community leaders and among rank and file. In practice, however, matters depended on the group involved. Eighty-four percent of community leaders and $61 \%$ of community members were willing to allow socialists the right to "make a speech in their community." among community leaders; it plummeted to $39 \%$ for atheists and $29 \%$ for communists among comparable rank and file. ${ }^{100}$

A generation later, abstract support for free speech remained and hostility to communists and atheists had waned. But a pattern of "pluralistic intolerance" emerged. ${ }^{101}$ No single group of speakers was targeted for repression by the majority of Americans, but most Americans could identify at least one particular group whose speech they would suppress. When survey researchers in the 1980s asked respondents to resolve questions of the free speech rights of the particular groups that they most disliked, results were comparable to Stouffer's. ${ }^{102}$ While $85 \%$ of respondents said that they "believe in free speech for all no matter what their views might be," only $34 \%$ of respondents said that their least liked groups should be allowed to hold rallies, and $50 \%$ said that they should be entitled to make speeches. ${ }^{103}$

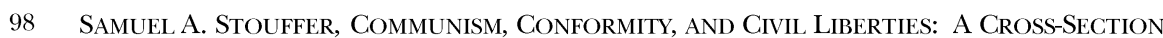
OF THE NATION SPEAKS ITS MIND 26-57 (1955).

99

$100 \quad I d$.

101 James L. Gibson, Intolerance and Political Repression in the United States: A Half Century after McCarthyism, 52 AM. J. POL. SCI. 96, 104 (2008) (noting lineage of "pluralistic intolerance" theory, which asserts intolerant impulses are likely to be benign when a variety of different groups are targets of intolerance on the part of different segments of the population, and malignant when intolerant impulses converge on a single target).

102 John L. Sullivan et AL., POlitical Tolerance AND American Democracy 55 (1982) (63\% said they would allow atheists to speak and $57 \%$ said they would allow communists to speak). See Herbert McClosky \& Alida Brill, Dimensions of Tolerance: What AMERICANS BELIEVE ABOUT CIVIL LIBERTIES 48-93 (1983).

103 SULLIVAN ET AL., supra note 102 at 203 ("free speech for all"); id. at 67 (tolerant actions). The most widely disliked groups were Communists and members of the KKK. Id. at 86109. Atheists, Black Panthers, and members of the Symbionese Liberation Army held the second rank. Id. Respondents in that survey were not asked about Nazis. However, an- 
A similar landscape has emerged in more recent surveys. ${ }^{104}$ In one striking 2005 study, James Gibson found that only 35.8\% of American public respondents would permit their most disliked group to speak in public, and only $29.2 \%$ would allow the group to demonstrate in public. ${ }^{105}$

other survey found that, while $90 \%$ of community leaders and $89 \%$ of respondents professed to "believe in free speech for all no matter what their views might be [,]" only $41 \%$ of opinion leaders and $18 \%$ of the public would allow the American Nazi Party to use a town hall for a public meeting. MCCLOSKY \& BRILL, supra note 102, at 50, 53.

104 See, e.g., Julie L. Andsager et al., Free Expression and Five Democratic Publics: SUPPORT FOR INDIVIDUAL AND MEDIA RIGHTS 74, 80 (2004) (freedom of speech rated by mean response at 9.34 out of 10 on a scale of importance, but mean response rated "speaking out in favor of a right wing dictatorship" or "a communist country" as protected only "under certain conditions"); Peter Hanson, Flag Burning, in PUBLIC OPINION AND Constitutional Controversy 184, 197 (Nathaniel Persily et al. eds., 2008) (92\% of American respondents supported the right to express unpopular opinions, $26 \%$ supported the right to wear offensive t-shirts, $22 \%$ supported the right to engage in racially offensive speech, and 21\% supported the right to burn or deface the American flag); GEORGE E. Marcus et al., With Malice Toward Some: How People Make Civil Liberties JUDGMENTS 27-31 (1995) (reviewing studies of political tolerance undertaken between 1955 and 1993); James H. Kuklinski et al., The Cognitive and Affective Bases of Political Tolerance Judgments, 35 AM. J. POL. SCI. 1, 14 (1991) ("If one finding has persisted ... it is that many Americans endorse civil liberties in the abstract but reject them in their concrete applications."); Jennifer L. Lambe, Dimensions of Censorship: Reconceptualizing Public Willingness to Censor, 7 COMM. L. \& POL'Y 187, 194 (2002) (reviewing studies finding "Americans continue to believe in freedom of speech.... in the abstract", but "support... wanes" in concrete situations); Nicole M. Lindner \& Brian A. Nosek, Alienable Speech: Ideological Variations in the Application of Free-Speech Principles 30 POL. PsYCHOL. 67 (2009) (reviewing earlier studies and finding in a new study that political liberals were less willing to censor than were political conservatives). Cf. PAUL SNIDERMAN ET AL, THE CLASH OF RIGHTS 22 (1996) (In a Canadian sample, 98\% of the public avowed allegiance to free speech principles; $35 \%$ were willing to allow their most disliked group to hold public rallies).

105 Gibson, supra note 101, at 104. Most frequently disliked groups were the KKK and Nazis, with radical Muslims, militarists, and atheists occupying the second rank, communists in third place, and gay rights activists, proponents of abortion, opponents of abortion, and Christian fundamentalists at the end of the spectrum. Id. at 102.

Gibson also found that if authorities decided to ban demonstrations by certain groups, $56.8 \%$ of the public would support a ban on demonstrations by radical Muslims, $46.9 \%$ would support a ban on demonstrations by atheists, and $39.1 \%$ would support a ban on demonstrations by religious fundamentalists. Id. at 104 .

This result does not appear to be contaminated by a post-9/11 decline in support for free expression. Although there was a brief spike (to 39\% then 49\%) in responses that "the First Amendment goes too far" during 2001 and 2002, by 2005, that response had abated to $23 \%$, near its pre-9/11 level. The State of the First Amendment: 2012, FIRST AMENDMENT CTR., 3-4 (2012), http://www.firstamendmentcenter.org/madison/wpcontent/uploads/2012/07/SOFA-2012.pdf.

On the other hand, a more recent survey undertaken from 2007 through 2011 found that $49.4 \%$ of respondents would allow their least-liked group to speak in public, and $43.1 \%$ would allow that group to hold rallies. James L. Gibson, Measuring Political Tolerance and General Support for Pro-Civil Liberties Policies: Notes, Evidence, and Cautions 77 PUB. OP. Q. 45, 51 (2013). 
One of the constraints that James Madison expected to contain the mischief of faction was the extended republic, ${ }^{106}$ and today pluralistic intolerance seems less likely to generate repression at the national level. Groups which constitute a disliked minority in one jurisdiction will often have access to enough aggregate power or allies nationally to prevent federal suppression.

But most government decisions (and-as we have seen-upwards of $70 \%$ of First Amendment cases involving content neutrality) arise not from decisions of state or national legislatures but from confrontations between village Hampdens and village tyrants. Especially with increasing political and cultural self-segregation of American municipalities, ${ }^{107}$ local public opinion will often converge on decisions to censor village Hampdens who flout locally homogeneous norms. Evangelicals decrying sodomy will not fare well in proportionality judgments by the San Francisco city council, nor will free thinkers get the benefit of the doubt in rural Arkansas. Equally important, the costs of repression will be borne most obviously by the village Hampdens, and the risks of tolerance will accrue to the village public at large. Censorship thus need not be rooted in official hostility: a potential village tyrant who is wholly indifferent to the content of proposed expression will have more reason to fear political discipline from a disgruntled local public than from a frustrated local insurgent. The official is likely to skew evaluation of risks and benefits accordingly.

Even in the absence of conscious decisions to censor village Hampdens, enjoining local authorities to determine the "proportionality" of the infringement on free expression will often be inadequate for the task of proportionately protecting speech. A variety of well documented decision making heuristics tend to warp judgment against locally disruptive or insurgent speech. ${ }^{108}$

106 The Federalist PAPER No. 10, at 134-35 (James Madison) (Benjamin Fletcher Wright, ed., 1961).

107 See generally BILl BISHOP, THE Big SORT: WHY THE CLUSTERING OF LIKE-Minded AMERICA IS TEARING Us APART (2008).

108 This perception is again not an entirely novel one. See, e.g., Geoffrey R. Stone, ContentNeutral Restrictions, 54 U. CHI. L. REv. 46, 73 (1987) ("[J]udges and jurors may be influenced by their own conscious or unconscious biases, which may undermine their ability to evaluate accurately and impartially the extent to which particular content-based restrictions actually impair the communication of specific, often disfavored, messages."). But it has been largely absent from commentary focusing on contemporary Supreme Court cases, and it is bolstered by the last two decades of research in behavioral decision theory. 
A robust line of research demonstrates that decision makers are less willing to accord weight to free speech principles when they feel threatened by the ideology or actions of the groups at issue. ${ }^{109} \mathrm{~A}$ sense of being under threat from other sources has a similar im-

109 See, e.g., James L. Gibson \& Amanda Gouws, Overcoming InTOLERANCE IN SOUTH AFricA: EXPERIMENTS IN DEMOCRATIC PERSUASION 186 (2003) ("[P]erceptions of threat are strongly related to political intolerance.”); Id. at 206; Darshan Goux et al., The War on Terror and Civil Liberties, in Public Opinion AND Constitutional Controversy 310, 313 (Nathaniel Persily et al. eds., 2008) ("[T] hreat—actual or perceived—activates authoritarian predispositions[.]"); MARCUS ET AL., supra note 104, at 9-10, 38 (anxiety and threat); J.L. Sullivan \& J.E. Transue, The Psychological Underpinnings of Democracy: A Selective Review of Research on Political Tolerance, Interpersonal Trust, and Social Capital, 50 ANN. Rev. PSYCHOL. 625, 630 (1999) (reviewing studies). 
pact. $^{110}$ And a sense of outrage tends to shift attention from the probability of a threat to its moral valence. ${ }^{111}$

These inclinations can be diluted to some extent when decision makers are directed to give "sober second thoughts" to the rights of groups they find threatening and are provided with arguments sup-

110 See, e.g., Darren W. Davis, Negative Liberty: Public Opinion ANd the Terrorist ATTACKS ON AMERICA 61, 80-85 (2007) (reviewing literature and finding that, after 9/11, a sense of personal vulnerability led otherwise libertarian respondents to abandon civil liberties); Marc J. Hetherington \& Elizabeth Suhay, Authoritarianism, Threat and Americans' Support for the War on Terror, 55 AM. J. POL. SCI. 546, 553, 555 (2011) (support for media censorship is highly correlated with authoritarianism, but non-authoritarians and authoritarians converge on censorship support where perceived threats of terrorism are acute); Miles Hewstone et al., Intergroup Bias, 53 ANN. REv. PsyCHOL. 575, 582 (2002) (reviewing "terror management" and "mortality salience" studies and finding that "people show greater intergroup bias when they are made aware of their own mortality"); see also Darren W. Davis \& Brian D. Silver, Personal Security vs. Civil Liberties after 9/11: Some Sobering Evidence from Sober Second Thoughts (Dep't of Political Sci., Mich. State Univ., Working Paper No. 4.1, 2003), available at https://www.msu.edu/ bsilver/soberthoughts.pdf. See generally MARCUS ET AL., supra note 104, at 211 ("global sense of threat" primes people for intolerance); Sheldon Solomon et al., Pride and Prejudice: Fear of Death and Social Behavior, in 9 CuRrent Directions In PsyChOlogiCAL SCI. 200 (2000) (reviewing studies "demonstrating that making death momentarily more salient increases liking for people who support one's worldview and hostility toward those with alternative worldviews"); John Cryderman \& Kevin Arceneaux, Abstract, Does Fear Motivate Critical Evaluations of Political Arguments? Emotion and DualProcessing Models of Persuasion, ANNUAL MEETING PAPER (Am. Pol. Sci. Ass'n), 2010, available at http://papers.ssrn.com/sol3/papers.cfm?abstract_id= 1644637 (in "an anxious state, individuals appear to rely on easy to use heuristics like source cues to gauge the effectiveness of the proposed solution").

I acknowledge that relatively abstract support for free assembly for "nonviolent protests against the United States Government" retained the allegiance of over $90 \%$ of the public in the aftermath of 9/11. DaVIS, NeGATIVE LiBERTY, supra note 110 , at 47,119 . It is also possible that, under circumstances where the actor's own norms of tolerance are foregrounded, mortality salience might increase adherence to those norms. Matthew T. Gailliot, Mortality Salience Increases Adherence to Salient Norms and Values, 34 PERSONALITY \& SOC. PSYCHOL. BulL. 993 (2008), available at http://psp.sagepub.com/content/34/7/993 (mortality salience increases interracial tolerance when norms of tolerance are triggered); $f$. Matthew Kugler \& Joel Cooper, Abstract, Still an American? Mortality Salience and Treatment of Suspected Terrorists, 40 J. APPLIED SOC. PSYCHOL. 3130 (2010) ("Reminders of mortality led participants to extend more procedural protections to an American terrorism suspect, but fewer toward a Saudi Arabian.").

111 See, e.g., Daniel Kahneman \& Shane Frederick, Representativeness Revisited: Attribute Substitution in Intuitive Judgment, in Heuristics AND BIASES: The Psychology OF INTUITIVE Judgment 49, 63 (Thomas Gilovich et al., eds., 2002); Daniel Kahneman \& Cass R. Sunstein, Cognitive Psychology of Moral Institutions, in Neurobiology of Human Values (JeanPierre P. Changeux et al., eds., 2005); Cass R. Sunstein, Probability Neglect: Emotions, Worst Cases, and Law, 112 YALE L. J. 61, 68 (2002); cf. GIBSON \& GOUWS, supra note 109 at 212 13 ("[The] degree of 'affront to the community' is crucial.... the degree of power that a group is perceived to hold has little to do with perceptions of the threat posed by the group ... people do not discount threats by... improbability."); MARCUS ET AL., supra note 104, at 215 (finding "[c]onsistent... failure of the probability manipulation to influence ... civil liberties decisions”). 
porting those rights. On the other hand, surveys and experiments regularly find that it is much easier to persuade initially tolerant decision-makers to adopt or approve intolerant decisions than to induce intolerant decision makers to switch to tolerance. ${ }^{112}$ Censorial inclinations are more easily triggered and more difficult to reverse.

The tendency to intolerance is exacerbated where the decision maker's attention is focused on the threatening aspect of disruptive speech. And this is precisely what a decision maker is asked to do if she is enjoined to determine whether a proposed infringement on speech is proportionate to a risk to other public values. The effect of salience in unduly heightening risk aversion is well documented in general. Risks that are easily brought to mind trump considerations that are less cognitively "available"; vivid examples of harm tempt decision-makers to focus on risks, and to discount more benign outcomes. This tendency combines with an inclination to focus on the degree of disruption associated with a scenario rather than its probability of leading decision-makers to overestimate the dangers of their occurrence. ${ }^{113}$ Framing a decision as a question of whether the risk of disruption is "proportionate" to the infringement is thus likely to lead to decisions that overemphasize risk. ${ }^{114}$

In the context of free speech, opinion polls and experiments find that, where a decision is framed as a matter of public order, willing-

112 See, e.g., DAVIS, NEGATIVE LiBERTY, supra note 110 at 111 (finding that, in a survey experiment post-9/11, "[i]t is easier to talk people into abandoning support for civil liberties than for security"); GIBSON \& GOUWS, supra note 109, at 162 (reporting "strong asymmetry in the behavioral consequences of tolerance and intolerance"); id. at 171-74, 216 (reporting that tolerant court decisions mildly increase tolerance; intolerant court decisions diminish political tolerance markedly); $i d$. at 215 ("[T] olerance is relatively malleable; intolerance is relative obdurate."); MARCUS ET AL., supra note 104, at 165 ("People who are intolerant are more intense in their attitudes."); id. at 207; James L. Gibson, $A$ Sober Second Thought: An Experiment in Persuading Russians to Tolerate, 42 AM. J. POL. SCI. 819,829 (1998) (finding impact of counter-arguments, but "[i]t is . . easier to convert tolerance to intolerance" than vice versa); Mark Peffley et al., A Multiple Values Model of Political Tolerance, 54 POL. RES. Q. 379, 398 (2001) (finding that the tolerant "are much more likely to move away from their position than the intolerant").

113 See, e.g., Daniel Kahneman, Thinking Fast AND Slow (2011). This has been a favorite theme of Professor Sunstein. See, e.g., Cass R. Sunstein, The Laws of Fear, 115 HARV. L. REv. 1119, (2002) (reviewing PAUl Slovic, The Perception OF RISK (2000)); Sunstein, supra note 111; Cass R. Sunstein, Fear and Liberty, 71 Soc. Res. 967, 977 (2004).

114 See, e.g., Dennis Chong \& James N. Druckman, Public-Elite Interactions: Puzzles in Search of Researchers, in ROBERT Y. SHAPIRO AND LAWRENCE R. JACOBS, THE OXFORD HANDBOOK OF AMERICAN Public OpINION AND THE MEDIA 171 (2011); KAHNEMAN, supra note 113; Dennis Chong \& James N. Druckman, Framing Theory, 10 ANN. REv. POL. SCI. 103 (2007); James N. Druckman, Abstract, On the Limits of Framing Effects: Who Can Frame? 63 J. POL. 1041 (2001) (acceptability of KKK rally is reduced when framed as public order rather than free speech issue). 
ness to allow insurgent groups to speak falls significantly. ${ }^{115}$ For street level bureaucrats called upon to make case-by-case determinations to discern the proportionality of potential censorship, the possible disruptive impact of speech is clearly framed, concrete, and salient to their core responsibilities, while the immediate value of insurgent speech is low and the long term concerns of public discourse remain abstract and tangential. ${ }^{116}$ A court engaging in case-by-case evaluations of proportionality, while perhaps more cognizant of free expression concerns, will still be tempted, if only subconsciously, to focus on easily recognizable harms. And for both courts and bureaucrats, a legal rule that begins with an inclination to balance costs and benefits will set the baseline from which losses and gains are judged differently_and less sympathetically to insurgent free speech claimants-from one which begins with a presumptive entitlement to content neutrality. ${ }^{117}$

Where the decision is made in an atmosphere of haste and pressure, the difficulties mount. Studies establish that exercising tolerance in evaluating persons and ideologies we dislike requires cognitive effort, and tolerance tends to collapse when decisions are made under physically or mentally trying circumstances. ${ }^{118}$

115 Thomas E. Nelson et al., Media Framing of a Civil Liberties Conflict and Its Effect on Tolerance, 91 AM. POL. SCI. REv. 567 (1997); Claudia Zilli Ramírez \& Maykel Verkuyten, Values, Media Framing, and Political Tolerance for Extremist Groups, 41 J. APPLIED SOC. PSYCHOL. 1583 (2011).

116 Indeed, strong institutional and game theoretic arguments suggest that even in the absence of cognitive biases, law enforcement agencies are likely to engage in excessive and indeed counter-productive speech suppression. Tiberiu Dragu, Is There a Trade-off between Security and Liberty? Executive Bias, Privacy Protections, and Terrorism Prevention, 105 AM. POL. SCI. Rev. 64 (2011); Tiberiu Dragu \& Mattias Polborn, The Rule of Law in the Fight Against Terrorism, 58 AM. J. POL. SCI. 511 (2014).

117 E.g., KAHNEMAN, supra note 113, at 278-99 (discussing prospect theory and endowment effect findings that demonstrate an inclination to give greater weight to losses from a baseline than to the prospect of gains); $i d$. at 349 ("Losses are weighted about twice as much as gains[.]"); Keith M. Marzilli Ericson \& Andreas Fuster, Expectations as Endowments: Evidence on Reference-Dependent Preferences from Exchange and Valuation Experiments 23 (Working Paper, 2010), available at http://papers.ssrn.com/sol3/papers.cfm? abstract_id=1505121.

118 Matthew T. Gailliot et al., Stereotypes and Prejudice in the Blood: Sucrose Drinks Reduce Prejudice and Stereotyping, 45 J. EXPERIMENTAL SOC. PSYCHOL. 288 (2009); Matthew T. Gailliot et al., Increasing Self-Regulatory Strength Can Reduce the Depleting Effect of Suppressing Stereotypes, 33 Personality \& Soc. Psychol. Bull. 281 (2007). See generally, Thomas F. Denson et al., Glucose Consumption Decreases Impulsive Aggression in Response to Provocation in Aggressive Individuals, 46 J. EXPERIMENTAL SOC. PsyCHOL. 1023 (2010); Martin S. Hagger et al., Ego Depletion and the Strength Model of Self-Control: A Meta-Analysis, 136 Psychol. BulL. 495 (2010). 
Finally, the robustly documented tendency toward motivated cognition leads decision makers to attend differentially to evidence that supports their initial inclinations. Without conscious bias, observers from opposing political camps are likely simply to see opposing facts and find opposing inferences persuasive. ${ }^{119}$ Again, the effect is exacerbated by a sense of threat. ${ }^{120}$ Faced with the challenge of determining the "proportionality" of interferences with First Amendment rights, it is likely that both government officials and reviewing courts will elevate their evaluation of the perceived risks associated with exercises of free expression rights which they find repugnant. ${ }^{121}$

The recent findings of Professor Kahn and his colleagues are powerfully illustrative. ${ }^{122}$ Presenting mock jurors with identical videos of protestors, the study found that "hierarchical/communitarian" subjects determined that demonstrators did not obstruct access or present a threat of violence in $70 \%$ of cases where the protests were said to be pro-life demonstrations outside of abortion clinics, but came to the same conclusion in only $16 \%$ of cases where they were

119 See Dan M. Kahan, The Supreme Court, 2010 Term - Foreword: Neutral Principles, Motivated Cognition, and Some Problems for Constitutional Law, 125 HARV. L. REv. 2, 19-22 (2011) (overview of the literature of motivated cognition and the mechanisms of biased search, biased assimilation and biased credibility evaluation). For the classic illustrative experiment, see Albert H. Hastorf \& Hadley Cantril, They Saw a Game: A Case Study, 49 J. ABNORMAL \& SOC. PSYCHOL. 129 (1954). Undergraduate partisans saw radically different numbers of football fouls in the same film of a Princeton/Dartmouth game, depending on their allegiance; Princeton undergraduates saw an average of 9.8 infractions by Dartmouth and Dartmouth students observed an average of 4.3 violations by their team. $I d$.

Researchers have found that decision makers are often willing to recognize motivated cognition in their opponents, but unable to recognize it in themselves. E.g. Kahan, supra, at 21. The tendency is exacerbated by an inclination to view others as disproportionately likely to be swayed by temptation or provocative speech. See, e.g., Albert C. Gunther, Overrating the X-Rating: The Third-Person Perception and Support for Censorship of Pornography, 45 J. COмм. 27 (1995); Hernando Rojas et al., For the Good of Others: Censorship and the Third-Person Effect, 8 INT'L J. PUB. OPINION RES. 142, 163-186 (1996); see also Scott O. Lilienfeld et al., Giving Debiasing Away: Can Psychological Research on Correcting Cognitive Errors Promote Human Welfare?, 4 PERSP. ON PSYCHOL. SCI. 390, 390-91 (2009) (reviewing "naive realism" literature).

120 Howard Lavine et al., Threat, Authoritarianism, and Selective Exposure to Information, 26 POL. PSYCHOL. 219 (2005).

121 See, e.g., Jonathan Haidt, The Righteous Mind: Why Good People Are Divided by POLITICS AND RELIGION, 35, passim (2012) (finding that human reasoning tends to seek out arguments and evidence that support intuitive moral judgments).

122 Dan M. Kahan et al., "They Saw a Protest": Cognitive Illiberalism and the Speech-Conduct Distinction, 64 STAN. L. REv. 851 (2012). For a study of similar import, see Avani Mehta Sood \& John M. Darley, The Plasticity of Harm in the Service of Criminalization Goals, 100 CALIF. L. REV. 1313, 1345 (2012) (“[W] hen informed that the law requires a finding of harm in order to penalize ... conduct, those who want to punish are significantly more likely to report the presence of harm, and report significantly greater levels of harm." Also finding the effect was exacerbated when the target was ideologically opposed to the rater). 
told that the images represented gay rights protestors outside of military recruiting stations. Results reversed for "egalitarian individualists": $76 \%$ of subjects observed neither obstruction nor incipient violence in the recruiting center condition, and only $28 \%$ reached similar conclusions for the abortion center. ${ }^{123}$

Faced with a village Hampden for whom they lack initial sympathy, therefore, we can expect potential village tyrants systematically to inflate the threats posed, and to underestimate the expressive interests at stake. A requirement of "proportionality" is thus likely to disproportionately burden free expression. Motivated cognition will incline potential First Amendment claimants to overestimate their chances of successfully asserting their claims, and constituents of the official to underestimate them. And while it is possible that trial courts may do better in untangling the facts, judges will not infrequently be subject to similar distortions. ${ }^{124}$

\section{Why a Focus on Viewpoint Neutrality and Motivation Is Inadequate to Motivate and Discipline Potential Village Tyrants}

A prohibition against viewpoint discrimination is inadequate to remedy these defects. Rarely do officials believe themselves to be acting with impure motives. And the motivated cognition literature strongly suggests that they will usually be unaware of the fact that the world they see is tinted by their own preconceptions. ${ }^{125}$

123 Kahan et al., supra note 122, at 880. Professor Kahan and his collaborators think they are measuring the frailties of the "speech/conduct" distinction. It seems to me that the questions they ask jurors go not to the distinction between speech and conduct but to efforts to discern either the magnitude of risk (threats of violence) or the nature of the motivation for official action. A strong content neutrality doctrine, focusing on the legal decision rule, avoids many of the problems of prediction and characterization.

124 See, e.g., Chris Guthrie et al., Blinking on the Bench: How Judges Decide Cases, 93 CORNELL L. Rev. 1 (2007); Chris Guthrie et al., Inside the Judicial Mind, 86 CoRnell L. Rev. 777, 77980 (2001); Jeffrey J. Rachlinski et al., Does Unconscious Racial Bias Affect Trial Judges?, 84 Notre DAME L. REV. 1195, 1225-26 (2009); cf. Gregory C. Sisk \& Michael Heise, Ideology "All the Way Down"? An Empirical Study of Establishment Clause Decisions in the Federal Courts, 110 MiCH. L. REV. 1201, 1245 (2012).

125 See Linda Babcock and Joshua Ferguson, Bounded Rationality in the Settlement Process: Empirical Evince on the Causes of Settlement Failure in Litigation 360, 371 in RESEARCH HANDBOOK ON THE ECONOMICS OF TORTS (Jennifer Arlen ed. 2013) (reviewing psychological literature on "introspection illusions" and "bias blind spots"); Ward Farnsworth, The Legal Regulation of Self-Serving Bias, 37 U.C. DAVIS L. REv. 567 (2003); see also Austin v. Mich. State Chamber of Commerce, 494 U.S. 652, 692 (1990) (Scalia, J., dissenting) ("[G] overnmental abridgment of liberty is always undertaken with the very best of announced objectives ... and often with the very best of genuinely intended objectives."); Cornelius v. NAACP Legal Def. \& Educ. Fund, 473 U.S. 788, 835-36 n.3 (1985) (Stevens, J., dissenting) ("A subconscious bias, based on nothing more than a habitual attitude of 
Then-professor Kagan acknowledged that "[o]fficials will not admit (often, will not themselves know) that a regulation of speech stems from hostility or self-interest[,]" but argued that the "content neutrality" doctrine will allow courts to "ferret out impermissible motives." ${ }^{, 26}$ She carefully acknowledged at some points, however, that even if the object is to "ferret out" motives, the actual inquiry of courts should be limited to the public acts of decision makers and should not seek to read their minds. ${ }^{127}$

Courts adopting the weak form of content neutrality doctrine that treats the "principal" issue as whether governing officials have acted out of hostility to particular views, by contrast, focus on the effort to discern purposes directly and invite officials subject to do likewise. Perhaps a sufficiently astute (Sherlock) Holmesian, or Freudian judge can accurately "ferret out" when unconscious motives are "afoot" by seeking to infer them from behavior. But on the street it seems more likely that the effort will devolve into a projective test. There will almost always be more than one potential motivation for suppression of locally obnoxious speech, and it is all too easy for a potential village tyrant to convince herself that it is a public spirited motivation that really drives her decision. For the judge, the temptation will always be to conclude that, notwithstanding the prima facie violation of content neutrality norms, she really "knows" that no invidious motivation is present in a decision of which she approves on the merits.

In the sampled cases, for example, courts which adopted the weak form approach of "ferreting out" censorial motives approved the prosecution of a homeowner who painted "screwed by the town" on his wall in colors that would be allowed for holiday displays, ${ }^{128}$ the imposition of fees on the International Women's Day March that were not imposed on the Cesar Chavez Day Parade, ${ }^{129}$ and a statute prohibiting payroll deductions for "public service" unions that opposed the governor while permitting deductions for "public safety" unions that supported him. ${ }^{130}$ A court exonerated police officers who arrested

disfavor ... may provide the actual explanation for a regulation that is honestly, but incorrectly, believed to be 'viewpoint neutral."”).

$127 I d$. at 441-42 ("The principle is that the First Amendment bans restrictions on speech arising from hostility, sympathy, or self-interest. The fact is that courts cannot enforce this ban directly.").

128 Brown v. Town of Cary, 706 F.3d 294, 297-98 (4th Cir 2013).

129 Int'l Women's Day March Planning Comm. v. City of San Antonio, 619 F.3d 346, 350, 358 (5th Cir. 2010).

130 Wis. Educ. Assn. Council v. Walker, 705 F.3d 640, 642 (7th Cir. 2013). 
anti-abortion protestors because of the graphic nature of their signs, because the officers could reasonably believe their actions were not content based. ${ }^{131}$

The best doctrine to constrain potential village tyrants is one with which officials can comply as part of standard operating procedure. It is difficult to grasp how an official can avoid acting on motives that she does know herself, or how she can disentangle impermissible unconscious motives from confirmation bias, other forms of motivated cognition, or simple incompetence. First Amendment claimants, who have no privileged access to the unconscious processes of decision makers, seem doomed to the converse fate: believing that decisions against them are ineluctably rooted in hostility.

\section{Content Neutrality, Heuristics, and Avoiding Village Tyranny}

A rule of strong content neutrality, by contrast, is well adapted to counterbalance predictable cognitive biases that warp judgment when potential village tyrant confronts aspiring village Hampden. It is easy enough to write an administrative manual that prohibits treating speakers differently because of what they say, regardless of motivation. And strong content neutrality provides robust political bulwarks for free expression.

\section{Debiasing}

To begin with, the question of whether a rule is "content neutral" is not one that requires decision makers to attend to the particular risks posed by the speech in question. A decision-maker who seeks to comply with her constitutional obligations-or to avoid constitutional sanction-need not evaluate the relation between risks to public order and value of speech opportunities, but need only attend to the nature of the rule. The frame in which she operates will not trigger undue dominance of public order concerns.

To be sure, in considering a content neutral rule on its merits, the official will confront the question of risks, but she will operate at a level of abstraction that taps into broadly felt affinities for free expression. As we have seen, commitment to broad norms of free expression attracts a consensus in the United States; it is only with specific application to disliked speakers that the consensus begins to unravel. If the question will not be whether vegans should disrupt

131 Lefemine v. Wideman, 672 F.3d 292 (4th Cir. 2012), vacated on other grounds, 133 S.Ct. 9 (2012). 
the tranquility of the Red Nose Run, but whether any outsiders may express themselves at events on public property, the broader consensus on free expression is more likely to predominate. ${ }^{132}$

The doctrine of content neutrality paired with the related strictures against vagueness and "unbridled discretion" "133 require that expression be regulated by clear ex ante rules which are broadly applicable. This structure detaches decision making from conditions most likely to generate intolerant suppression of speech.

Ex ante decisions on broad rules require the decision maker to focus attention on situations that trigger positive as well as negative associations. Rather than anchoring on a particular obnoxious village Hampden, the requirement that ex ante rules be content neutral forces the decision maker to consider the range of potential speakers who may wish to express themselves. ${ }^{134}$ In considering this range, the availability heuristic suggests that it is the most common (and hence the least socially aberrant and disruptive) instances that are likely to predominate. ${ }^{135}$ Even where the least-liked speakers are salient, the

132 See, e.g., MARCUS ET AL., supra note 104, at 128 ("Framing issues of tolerance within the broader domain of democratic values can diminish the role of threat.").

133 E.g., Forsyth Cnty. v. Nationalist Movement, 505 U.S. 123, 133 (1992) ("The First Amendment prohibits the vesting of such unbridled discretion in a government official.") (citation omitted); City of Lakewood v. Plain Dealer Publ'g Co., 486 U.S. 750, 757 (1988) ("long line of precedent" based on "time-tested knowledge that in the area of free expression a licensing statute placing unbridled discretion in the hands of a government official or agency... may result in censorship"); see Thomas v. Chi. Park Dist., 534 U.S. 316, 323 (2002) ("Where the licensing official enjoys unduly broad discretion in determining whether to grant or deny a permit, there is a risk that he will favor or disfavor speech based on its content."); FW/PBS, Inc. v. City of Dallas, 493 U.S. 215, 226 (1990) (citing Lakewood, 486 U.S. at 757).

Strictures against vague regulation also take on particular salience for regulation of expression. E.g., FCG v. Fox Television Stations, Inc., 132 S. Ct. 2307, 2318 (2012); Reno v. ACLU, 521 U.S. 844, 870-71 (1997); Baggett v. Bullitt, 377 U.S. 360, 372 (1964); see, e.g., Citizens United v. FEC, 558 U.S. 310, 324 (2010) ("The First Amendment does not permit laws that force speakers to retain a campaign finance attorney, conduct demographic marketing research, or seek declaratory rulings before discussing the most salient political issues of our day. Prolix laws chill speech for the same reason that vague laws chill speech[.]").

134 MARCUS ET AL., supra note 104, at 217 ("citizens who held no malice toward the group" did not dilute standing inclinations to recognize civil liberties); Lilienfeld et al., supra note 119, at 393 (reviewing studies and finding that perspective-taking and consideration of alternatives alleviates cognitive bias); $c f$. KAHNEMAN, supra note 113, at 119-128 (discussing the anchoring effect).

135 See, e.g., KAHNEMAN, supra note 113, at 128-36 (discussing an anchoring phenomenon in which vivid and easily accessed information is over-weighted); RICHARD NISBETT \& LEE Ross, Human InfERence: Strategies ANd SHortComings OF SOCIAL Judgment 18-19 (1980); Amos Tversky \& Daniel Kahneman, Availability: A Heuristic for Judging Frequency and Probability, in JUdgMent Under UnCERTAINTY: HeURistics AND BIASES 163, 163-78 
requirement to consider potential effects on a broad class of speakers can dissipate cognitive bias. ${ }^{136}$ And as Professor Kalven argued in planting the seeds of content neutrality,

Everyone at some time or other loves a parade whatever its effect on traffic and other uses of public streets. Municipalities pressed by concern with the protest movement may be inhibited in any rush to flat nondiscriminatory prohibitions by the difficulty of distinguishing between the parades we like and others. Equal protection may, therefore, require freedom for the parades we hate.

Content neutral ex ante decision making is less likely to be distorted by heuristics of fear and outrage. The question of whether a particular rule is "content neutral" is not one that requires either a street level bureaucrat or a reviewing court to attend to the attractive or repellant qualities of the speech in question. Studies show tolerance is more difficult to maintain under pressure; ex ante decision making is less likely to take place under conditions of threat and anxiety. ${ }^{138}$

(Daniel Kahneman et al. eds., 1982); Roger G. Noll \& James E. Krier, Some Implications of Cognitive Psychology for Risk Regulation, 19 J. LEGAL STUD. 747, 755 (1990).

136 KAHNEMAN, supra note 113, at 361 ("Rationality is generally served by broader and more comprehensive frames[.]"). Researchers invoke and use this mechanism in a series of decision contexts. See Stefan M. Herzog \& Ralph Hertwig, The Wisdom of Many in One Mind: Improving Individual Judgments With Dialectical Bootstrapping, 20 PSYCHOL. SCI., 231, 231 (2009) ("[P] eople can enhance the quality of their quantitative judgments by averaging their first estimate with a second dialectical estimate." (emphasis omitted)); Edward Vul \& Harold Pashler, Measuring the Crowd Within: Probabilistic Representations within Individuals, 19 PSYCHOL. SCI. 645, 647 (2008) ("[A] forced second guess contributes additional information, such that the average of two guesses is better than either guess alone."); $f$. Heiko Rauhut \& Jan Lorenz, The Wisdom of Crowds in One Mind: How Individuals Can Simulate the Knowledge of Diverse Societies to Reach Better Decisions, 55 J. MATHEMATICAL PSYCHOL. 191 (2011).

"Reference class forecasting" alleviates cognitive bias by inducing decision makers to establish and take account of the distribution of attributes typical of similar events. See, e.g., Bent Flyvbjerg, Curbing Optimism Bias and Strategic Misrepresentation in Planning: Reference Class Forecasting in Practice, 16 EUR. PLAN. STUD. 6 (2008) (describing theory and implementation); Katherine L. Milkman et al., How Can Decision Making Be Improved?, 4 PERSP. ON PSYCHOL. SCI. 379, 381 (2009) (advocating "trying to remove oneself mentally from a specific situation or to consider the class of decisions to which the current problem belongs" (internal citation omitted)). Generalization similarly decreases excessive loss aversion. See Katherine L. Milkman et al., Policy Bundling to Overcome Loss Aversion: A Method for Improving Legislative Outcomes, 117 ORGANIZATIONAL BEHAV. \& HuM. DECISION PROCESSES 158 (2012) (finding that combining decisions diminished focus on losses and heightened focus on gains).

137 Kalven, Jr., supra note 6 , at 30.

It is also a well rooted finding that while decision makers' evaluations of facts are likely to be biased in the direction of self interest, decisions made before interests are disclosed avoid such bias. E.g., Linda Babcock \& George Loewenstein, Explaining Bargaining Impasse: The Role of Self-Serving Biases, 11 J. ECON. PERSP. 109, 114, 120 (1997).

138 See Lilienfeld et al., supra note 119, at 393-94 (reviewing studies finding that delayed decision-making alleviates cognitive bias); Milkman et al., supra note 136, at 381 (highlighting 
Likewise "sober second thoughts" can dilute intolerance generated by outrage, and the requirement of adopting ex ante general rules that potentially impact a range of cases has a tendency to induce such a mindset. $^{139}$

\section{Bright Lines, Motivated Cognition, and Learning}

Cost-benefit analysis is often a difficult business; it requires accurate information about both sides of the ledger. Full information about the probabilities and magnitudes of both costs and benefits, however, is not likely to be easily available to potential village tyrants making decisions about village Hampdens.

Local authorities have crowded agendas and limited resources for inquiry. Claims by village Hampdens will not often rise to the top of the research queue. In the face of uncertainty, street level bureaucrats and local regulators are unlikely to give the benefit of the doubt to insurgent speech in judging whether the public interest in suppressing speech is "proportionate." Indeed, findings regarding motivated cognition suggest they will frequently be unable to discern that real doubt exists. ${ }^{140}$ Even honest introspection will frequently lead them to conclude that they are motivated not by hostility to ideas but by concern for public order and convenience.

An obligation to evaluate case-by-case proportionality, moreover, leaves ample leeway for conscious manipulation. Reviewing courts, like citizens seeking to assert their rights, will often be ill equipped to pierce the fog of biased perception and rationalization. ${ }^{141}$ And rules

research suggesting "any change in a decision's context that promotes coolheaded ... thinking has the potential to reduce common biases").

139 See, e.g., GIBSON \& GOUWS, supra note 109, at 115 ("[D]eliberation may be most effective when it is separated from the immediate context of the controversy ...."); MARCUS ET AL., supra note 104 at 222-23; Gibson, A Sober Second Thought, supra note 112, at 829; $\mathrm{f}$. Sood \& Darley, supra note 122, at 1323-24 (suggesting generalization launders motivated cognition).

140 Lilienfeld, et al., supra note 119, at 392-94 (reviewing studies finding a "bias blind spot"); Dan M. Kahan, Cognitive Bias and the Constitution 88 CHI.KENT L. REv. 367, 389 (2013) ("Legislators and law enforcers need not be consciously motivated.... [D] espite their intentions they could all end up participating in the culturally partisan allocation of legal benefits and burdens because of their tendency to perceive behavior that threatens their values as threatening their collective health, safety, security, or prosperity."); Emily Pronin et al., Objectivity in the Eye of the Beholder: Divergent Perceptions of Bias in Self Versus Others, 111 PsyCHOL. REv. 781, 784-87 (2004) (reviewing studies).

141 City of Lakewood v. Plain Dealer Publ'g Co., 486 U.S. 750, 758-61 (1988) ("Without these guideposts, post hoc rationalizations by the licensing official and the use of shifting or illegitimate criteria are far too easy ... the general application of the statute to areas unrelated to expression will provide the courts a yardstick with which to measure the licensor's occasional speech-related decision.”). 
enjoining proportionality or purity of motives leave First Amendment claimants vulnerable to the motivated cognition of trial judges and juries. The magnitude and probability of risk are fundamentally factual judgments; so too are issues of censorial motivation. Appellate courts are enjoined by some strands of First Amendment doctrine "to 'make an independent examination of the whole record' in order to make sure that 'the judgment does not constitute a forbidden intrusion on the field of free expression." "142 But relying on law clerks and busy judges to parse extensive records in the teeth of jury verdicts or trial court findings to vindicate the rights of village Hampdens provides an unstable bulwark.

For citizens, potential village tyrants, and reviewing courts, it is more straightforward and robust to discern whether a rule distinguishes on the basis of content. As Justice William Brennan argued,

The traditional approach sets forth a bright-line rule: any restriction on speech, the application of which turns on the content of the speech, is a content-based restriction regardless of the motivation that lies behind it. That, to my mind, has always been implicit in the fact that we term the test a "content-based" test rather than a "motivation-based" test. The traditional rule thus provides clear guidance. Governments can ascertain the scope of impermissible regulation. Individuals can ascertain the scope of their constitutional protection. The [analysis of purpose], in contrast, plunges courts into the morass of legislative motive, a notoriously hazardous and indeterminate inquiry ....

In strong form analysis most information needed to determine whether a rule is content based can be gleaned from its operative elements without recourse to inferences, evaluations, or balancing of necessities. There will thus be less room for the distortions of motivated cognition. ${ }^{144}$ And a clear doctrine barring content based rules

142 Snyder v. Phelps, 562 U.S. 1, 7 (2011) (quoting Bose Corp. v. Consumers Union of U.S., Inc., 466 U.S. 485, 499 (1984) (quoting N.Y. Times Co. v. Sullivan, 376 U.S. 254, 285 (1964))); Randall v. Sorrell, 548 U.S. 230, 249 (2006); Hurley v. Irish-Am. Gay, Lesbian \& Bisexual Grp. of Bos., 515 U.S. 557, 567-68 (1995); Gentile v. State Bar of Nev., 501 U.S. 1030, 1038 (1991); Rankin v. McPherson, 483 U.S. 378, 386 n.9 (1987).

143 Boos v. Barry, 485 U.S. 312, 335-36 (1988) (Brennan, J., concurring in part and concurring in judgment).

144 See, e.g., Richard J. Reifenberg, The Self-Serving Bias and the Use of Objective and Subjective Methods for Measuring Success and Failure, 126 J. Soc. PsYCHOL. 627, 629-30 (1986); cf. Karen Siegel-Jacobs \& J. Frank Yates, Effects of Procedural and Outcome Accountability on Judgment Quality, 65 Organizational Behav. \& Hum. Decision Processes 1 (1996) (finding that a requirement to account for predictions induces subjects to treat cues consistently and improves prediction). 
of decision is likely to leave both officials and courts more inclined and more able to confront censorial temptations. ${ }^{145}$

Over time, moreover, the experience of being required to deal with and accommodate village Hampdens as the cost of permitting parades "we all love" is likely to have a salutary effect on both local officials and reviewing courts. For officials inclined to overestimate the danger of insurgent speech, the absence of concrete disruption in an initial case will anchor their expectations at a real rather than hypothetical level of threat. If, as is often true, ex ante fears are dispelled by reality, being forced to deal with insurgent speech imposes a variety of psychic yoga: stretching the psyche leaves it more flexible and robust in the future. ${ }^{146}$ Officials will discern that they need not rely on the crutch of censorship to accomplish legitimate goals. ${ }^{147}$

Having sacrificed their initial sensibilities on behalf of "the speech we hate," moreover, judges and officials will find it even more important to stand firm in the face of demands to censor "speech we hate a bit less," or "the inconvenient speech we may come to admire..$^{148}$

145 With respect to officials, see Katie R. Eyer, That's Not Discrimination: American Beliefs and the Limits of Anti-Discrimination Law, 96 MINN. L. Rev. 1275, 1351 (2012) (reviewing psychology literature and finding that "well-defined and non-ambiguous constraints on decision-making ... can be significantly more effective at constraining psychological biases"); Yuval Feldman \& Alon Harel, Social Norms, Self-Interest and Ambiguity of Legal Norms: An Experimental Analysis of the Rule vs. Standard Dilemma, 4 REv. L. \& ECON. 81, 82 (2008) ("As legal norms become more specific and rule-like, the influence of [conflicting] social norms [and self interest] lessens.").

With respect to courts, see Denver Area Educ. Telecomms. Consortium, Inc. v. FCC, 518 U.S. 727, 774 (1996) (Souter, J., concurring) ("Reviewing speech regulations under fairly strict categorical rules keeps the starch in the standards for those moments when the daily politics cries loudest for limiting what may be said.") quoted in United States v. Playboy Entm't Grp., Inc., 529 U.S. 803, 830-31 (2000) (Thomas, J., concurring); Denver Area Educ. Telcomms. Consortium, 518 U.S. at 785 (Kennedy, J., concurring in part, concurring in the judgment in part, and dissenting in part) (" $[\mathrm{T}]$ he creation of standards and adherence to them, even when it means affording protection to speech unpopular or distasteful, is the central achievement of our First Amendment jurisprudence. Standards are the means by which we state in advance how to test a law's validity, rather than letting the height of the bar be determined by the apparent exigencies of the day.").

146 Cf. LeE C. Bollinger, The Tolerant Society: Freedom of SpeEch ANd Extremist SPEECH IN AMERICA 121 (1986) ("[Q]ualities we acquire by stretching ourselves in one area of activity spill over into other areas of life where those qualities are also needed."); Id. at 125 ("To straighten a bent stick you bend it back the other way." (citation omitted)).

147 This, of course, assumes that chaos does not ensue.

148 Frode Alfnes et al., Cognitive Dissonance as a Means of Reducing Hypothetical Bias, 37 EuR. Rev. Of Agric. Econ. 147, 147-48 (2010); Donna Eisenstadt et al., Dissonance and Prejudice: Personal Costs, Choice, and Change in Attitudes and Racial Benefits Following Counterattitudinal Advocacy That Benefits a Minority, 27 BASIC \& APPLIED PsyCHOL. 127, 127-28 (2005); Michael R. Leippe \& Donna Eisenstadt, Generalization of Dissonance Reduction: Decreasing Prejudice Through Induced Compliance, 67 J. Personality \& SOC. PsyChOL. 395, 395-96 


\section{Protective Politics}

The appeal of content neutrality extends beyond harnessing heuristics to the cause of free expression. Where decision makers must adopt ex ante content neutral rules, the threat of a rule that inhibits all parades will generate opposition from the full spectrum of constituencies who may find parades attractive, from evangelists in Arkansas to gay rights proponents in San Francisco. The point, in turn, is familiar across the ideological spectrum. Justice Brennan maintained,

Although an inquiry into motive is sometimes a useful supplement, the best protection against governmental attempts to squelch opposition has never lain in our ability to assess the purity of legislative motive but rather in the requirement that the government act through content-neutral means that restrict expression the government favors as well as expression it disfavors. In Justice Jackson's felicitous words of nearly [forty] years ago: "Courts can take no better measure to assure that laws will be just than to require that laws be equal in operation." Railway Express Agency, Inc. v. New York, 336 U. S. 106, 113 (1949) (concurring opinion).

Justice O'Connor acknowledged,

When the State imposes a generally applicable tax, there is little cause for concern. We need not fear that a government will destroy a selected group of taxpayers by burdensome taxation if it must impose the same burden on the rest of its constituency. See Railway Express Agency, Inc. v. New York, 336 U.S 106, 112-113 (1949) (Jackson, J., concurring). When the State singles out the press, though, the political constraints that prevent a legislature from passing crippling taxes of general applicability are weakened, and the threat of burdensome taxes becomes acute. ${ }^{150}$

And Chief Justice Rehnquist observed:

(1994); see supra note 137 and infra note 173 and accompanying text; $c f$. MARCUS ET AL., supra note 104 , at 120 (" $[\mathrm{I}] \mathrm{f}$ the idea is important to a person or is used frequently ... [or] has been recently accessed, it may come to mind more readily[.]").

This effect may be on display in the strength of Justice Kennedy's enthusiasm for free expression: his first free speech opinion on the Court found him in anguished concurrence in Texas $v$. Johnson, sustaining a challenge to a prohibition on flag desecration. Texas v. Johnson, 491 U.S. 397, 420 (1989) (Kennedy, J., concurring) ("The hard fact is that sometimes we must make decisions we do not like.").

149 Boos v. Barry, 485 U.S. 312, 336-37 (1988) (Brennan, J., concurring in part, concurring in the judgment in part, and dissenting in part).

150 Minn. Star \& Tribune Co. v. Minn. Comm'r of Revenue, 460 U.S. 575, 585 (1983). See Turner Broad. Sys., Inc. v. FCC, 512 U.S. 622, 676 (1994) (O'Connor, J., concurring in part and dissenting in part) ("Laws that treat all speakers equally are relatively poor tools for controlling public debate, and their very generality creates a substantial political check that prevents them from being unduly burdensome."). 
Injunctions also carry greater risks of censorship and discriminatory application than do general ordinances. "[T]here is no more effective practical guaranty against arbitrary and unreasonable government than to require that the principles of law which officials would impose upon a minority must be imposed generally." Railway Express Agency, Inc. v. New York, 336 U.S 106, 112-113 (1949)..$^{151}$

A rule of content neutrality does not disable officials from imposing "proportionate" limits on expression. But it means that officials must be willing to live with the prospect of applying the prohibition to their own favorite speakers and imposing it on their constituents. ${ }^{152}$ Equally important, the official must be able to defend the claim of proportionality not only in court but to the broader public. ${ }^{153}$

An effort to gerrymander prohibition of speech to avoid politically powerful constituencies casts doubt on whether the prohibition is truly justified. ${ }^{154}$ And with gerrymandering prohibited, first line of defense of free expression is not the limited insight of the official into her own biases or her scrupulousness in seeking a true balance between public necessity and free speech, but rather her better developed ability to calculate the political consequences of suppressing a broad swath of speakers.

151 Madsen v. Women's Health Ctr., Inc., 512 U.S. 753, 764-65 (1994). See, e.g., Eugene Volokh, Speech as Conduct: Generally Applicable Laws, Illegal Courses of Conduct, "SituationAltering Utterances," and the Uncharted Zones, 90 CORNELL L. Rev. 1277, 1305-06 (2005) (“[T] he most severe hypothetical content-neutral restrictions-for instance, a ban on printing, justified by the environmental harms caused by the process of making paperare sure to remain just hypotheticals: They are politically implausible precisely because they burden so much speech." (citation omitted)).

152 For a useful recent discussion of the ways in which prospectivity and generality generate impartiality, see Adrian Vermeule, MeCHANISMS OF DEMOCRACY, INSTITUTIONAL DESIGN WRIT SMALL 27-49 (2007) (and sources cited).

153 E.g., Stone, supra note 108 , at 76 ("The more speakers in a community are affected, the more government would be forced to ensure its purposes truly were substantial before it enacted the restriction.").

154 See City of Ladue v. Gilleo, 512 U.S. 43, 52 (1994) ("Exemptions from an otherwise legitimate regulation of a medium of speech ... may diminish the credibility of the government's rationale for restricting speech in the first place."); Niemotko v. Maryland, 340 U.S. 268, 272-73 (1951) (" $[\mathrm{I}] \mathrm{t}$ is argued that state and city officials should have the power to exclude religious groups, as such, from the use of the public parks.... [W] hatever force this contention could possibly have is lost in the light of the testimony of the Mayor at the trial that ... permits had always been issued for religious organizations and Sundayschool picnics. We might also point out that the attempt to designate the park as a sanctuary for peace and quiet... is also more than slightly inconsistent, since, on the first Sunday here involved, the park was the situs for the Flag Day ceremony of the Order of Elks."). 


\section{Robustness and Stability}

A strong form content neutrality doctrine has a final salutary effect. Under standard arguments in positive political theory, one pillar of a stable constitutional system is the understanding of each faction that over time political alignments change and a variety of currently ascendant groups have stakes in the constitutional rights of short-term losers. Rules that protect an out group at one point can be expected by contemporary potential oppressors to protect their own interests at a later point. ${ }^{155}$ The combination of decentralized political decision making and consistent judicial enforcement of content neutrality facilitates that dynamic in the arena of free expression. Where restrictions on expression are judged by abstract rules that tend toward generality, rather than case-by-case proportionality or fact-bound determinations of motivation, First Amendment challenges sustained on behalf of a Hampden in one village will redound to the benefit of her ideological kindred in other venues where they face opposing potential tyrants. Repeat-playing organizations representing village Hampdens (whether the ACLU or the Alliance Defense Fund) will have an incentive to invoke the general rule regularly in litigation on behalf of their client village Hampdens and to devote more effort than is marginally justified in the particular case to supporting that rule. Remember: over a third of content neutrality litigants in lower courts, and almost two thirds of ideological plaintiffs, are represented by repeat-playing attorneys.

But each victory will also strengthen the hand of village Hampdens across the ideological spectrum. Decisions based on a protective rule of content neutrality will redound to the plaintiff's ideological opposite Hampdens in the neighboring villages where majorities and minorities are reversed. Successful invocation by each side will yield a continuing stream of examples that highlight the breadth of the doctrine's beneficiaries. Each political faction, if cognizant of

155 E.g., James D. Fearon, Self-Enforcing Democracy, 126 Q. J. ECON. 1661, 1662-64 (2011); Gillian K. Hadfield \& Barry R. Weingast, Law Without the State: Legal Attributes and the Coordination of Decentralized Collective Punishment, 1 J.L. \& CTS. 3, 9 (2013); Gillian K. Hadfield \& Barry R. Weingast, What is Law? A Coordination Model of the Characteristics of Legal Order, 4 J. Legal Analysis 471, 475-76 (2012); Daryl J. Levinson, Parchment and Politics: The Positive Puzzle of Constitutional Commitment, 124 HARV. L. REv. 657, 670 (2011); Sonia Mittal \& Barry R. Weingast, Constitutional Stability and the Deferential Court, 13 U. PA. J. ConsT. L. 337, 341 (2010); Barry R. Weingast, The Political Foundations of Democracy and the Rule of Law, 91 AM. POL. SCI. REV. 245, 245-46 (1997); Barry R. Weingast, Self-Enforcing Constitutions: With an Application to Democratic Stability in America's First Century 6-7 (Stanford Univ. Hoover Inst. on War, Revolution \& Peace, Working Paper, November 2010), available at http:/ /ssrn.com/abstract=1153527. 
this effect, will thus have reason to support and nourish the general rule as long as it values its own freedom more than the ability to censor opponents.

To take one example in the lower court sample, the plaintiff in Nieto v. Flatau, ${ }^{156}$ a retired marine employed at Camp Lejeune whose son had been killed aboard the USS Cole, prevailed on a content neutrality claim asserting his right to continue to drive to work in a truck with bumper stickers bearing a noxious anti-Islamic message because the base had permitted equally offensive bumper stickers directed at other targets. ${ }^{157} \mathrm{Mr}$. Nieto was represented by the rightleaning "American Freedom Law Center." Eis8 Eight months later, Nieto was cited with approval for the proposition that it "is well established that a content-neutral policy cannot be discriminatorily enforced" in Ross $v$. Early, a case brought by animal rights activists whose circus protest had been disrupted by police. ${ }^{159}$ Mr. Ross was represented by an attorney who announces he "will only accept cases involving animals on behalf of responsible and conscientious owners who view the animal not as property but as a member of their family." 160

As we have seen, in the lower courts, successful litigants invoking First Amendment norms of content neutrality come symmetrically from groups of the cultural and political left and right. The ACLU and progressive movement lawyers represent animal rights protestors and the Occupy movement, with the occasional neo-Nazi thrown in for spice. Evangelists, anti-abortion protestors, and libertarians are represented by the Alliance Defense Fund and an array of cognates from the American Liberties Institute to the Thomas Merton Center. Unaffiliated village Hampdens, ranging from an existentialist filmmaker challenging a prohibition on blasphemy to local curmudgeons, make up an almost equal cohort of plaintiffs, and are occasionally represented by repeat-playing counsel.

The lived experience of content neutrality thus gives a wide variety of political actors a stake in the system of free expression. When evangelists and pornographers, animal rights activists and libertarians can all seek and find visible shelter under the banner of content neutrality, a politically responsive official seeking to convince constitu-

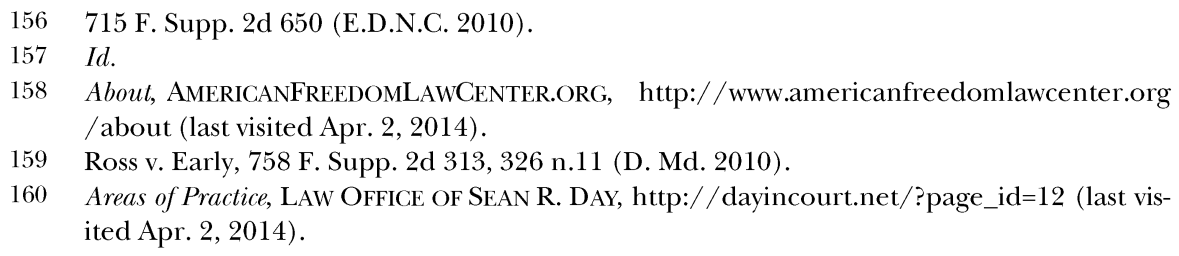


ents that she is acting appropriately in declining to repress locally repugnant expression can proclaim plausibly that the commitment to protecting village Hampdens is one in which all have an interest. She need not convince skeptical and offended constituents that their concerns are either illegitimate (as motivation doctrines would require) or unfounded and disproportionate. She need only ask constituents whether they are willing to put their expression or those of their allies at the same risk in neighboring villages that they would impose on their enemies in their own.

Studies tend to show that compliance with legal norms is enhanced by the perceived fairness of the norm. ${ }^{161}$ It is not difficult for an official to understand, internalize, and apply a norm of strong content neutrality in evaluating the claims of village Hampdens. And it is easy enough to explain and defend it to her constituents. The official need not be conversant with Kant, Rawls, and Nash equilibria. The Golden Rule, maxims regarding geese, ganders, and motes in one's brothers' eyes are perfectly adequate to the task. By contrast, announcing that there is "not proportionate" risk associated with the speech, or that the request for suppression is associated with improper motives, is likely to provoke rather than appease demands for censorship.

The decentralized quality of American political decision making ensures a continued flow of cases in the federal courts; everyone's constituency will confront a local tyrant in some village. Particularist doctrines focusing on proportionality or motivation may allow the Supreme Court majority to get the "right" answer. But they give weak guidance to lower courts, even weaker guidance to potential village tyrants, and little incentive for political constituencies to rally behind them. And they are likely to allow a five-member majority of the Court to protect its favorite speakers without extending the benefits of its doctrine to opposing points of view.

Categorical requirements of content neutrality, by contrast, provide an array of political constituencies with a stake in the stability and protectiveness of constitutional doctrine. Strong content neutrality generates a richer stock of vivid examples and thus a more powerful normative protection for expression, both at the Supreme

161 E.g., TOM R. Tyler, Why PEOPLe OBey THe LAW 170-78 (1990); Jonathan Jackson et al., Why Do People Comply with the Law? Legitimacy and the Influence of Legal Institutions, 52 BRIT. J. Criminology 1051, 1052 (2012); Kristina Murphy, The Role of Trust in Nurturing Compliance: A Study of Accused Tax Avoiders, 28 L. \& Hum. BeHAV. 187, 188 (2004); Tom R. Tyler \& Jeffrey Fagan, Legitimacy and Cooperation: Why Do People Help the Police Fight Crime in Their Communities?, 6 OHIO ST. J. CRIM. L. 231, 234-35 (2008). 
Court level and in the lower courts. Most local officials can understand that if mendacious claimants to military honors and purveyors of bloody dogfight videos are protected by the First Amendment, a claim that there should be an exception from the demands of content neutrality for the noxious expression of their least favorite local Hampden is not viable. The same will rarely be true if the Supreme Court makes cases turn on the nice balance between costs and benefits, or the dubious virtues of official introspection.

Researchers have found that for legal elites (though not for political elites generally) there is a substantial difference between support of civil liberties on "issues on which courts have set a clear precedent supporting civil liberties and issues not addressed clearly by the courts." ${ }^{162}$ And psychological salience literature suggests that it is not only clear but vivid examples that occupy the attention. ${ }^{163}$ When a village Hampden negotiates with the village solicitor, or when the potential village tyrant consults counsel, the depth and richness of easily available precedent is likely to condition the outcome.

One final virtue. Professor Graber has argued that political "regimes" appointing liberal Justices will tend to avoid First Amendment violations, leaving those Justices with less opportunity to embody their views in case law, since there are no violations to strike down, while conservative "regimes" will tend to appoint Justices that will uphold their incursions. ${ }^{164}$ Leaving aside the fact that life tenure ensures that Justices will end up reviewing the handiwork of regimes that have not appointed them, village tyrants predictably undertake incursions on free expression that are at odds with national regimes. In our sample, both Left and Right invoke content neutrality at roughly equal rates. Local adjudication therefore provides repeated occasions to authoritatively embed protective views in case law. Broad doctrines of content neutrality mobilize a variety of constituencies, which are likely to appeal to a broader array of "regimes."

MARCUS ET AL, supra note 104 at 118; see GIBSON \& GOUWS, supra note 109, at 156. See NisBETT \& ROSS, supra note 135, at 43-62 (identifying prime contributors to salience: “ (a) emotionally interesting, (b) concrete and imagery-provoking, and (c) proximate in a sensory, temporal, or spatial way"); HANDBOOK OF SOCIAL COGNITION 440-41 (Robert S. Wyer, Jr. \& Thomas K. Srull eds., 2d ed. 1994) (vivid information captures attention and encourages processing).

164 Mark A. Graber, Antebellum Perspectives on Free Speech, 10 WM. \& MARY BILL RTs. J. 779 (2002). 


\section{IV. “The Spirit of the People”: Constitutional Culture in the LAND OF THE FREE AND THE HOME OF THE BRAVE}

The arguments so far support the use of "content neutrality" as a way of constraining village tyrants. Do they apply to statutes duly adopted by the Congress of the United States on all matters involving expression? Do we really think that statutes punishing serial liars who debase military honors they never earned or the purveyors of lurid images of animal abuse result largely from cognitive errors or unacknowledged censorial impulses ${ }^{165}$ Or that Congress is congenitally infected with cognitive error and bias to a degree that should empower courts across the board?

Many of the heuristics identified above can taint the decisions of national legislators. But if we are in doubt, a second strand of analysis argues for retaining a strong doctrine of content neutrality at both national and local levels. Constitutional doctrine is properly concerned not only with the "spirit of the government" but the "spirit of the people."

A well-worn token of constitutional argument, minted by Yale Law School Dean Eugene Victor Debs Rostow in the 1950s, holds that "[t]he Supreme Court is, among other things, an educational body, and the Justices are inevitably teachers in a vital national seminar." Dean Rostow, after lauding the Court's didactic role went on to lament the then-recent abandonment of civil liberties in the face of inchoate fears of subversion in Dennis v. United States. ${ }^{167}$ Yet Dean Rostow tempered his admonition,

"Of course the Court should keep its powder dry and avoid wasting its ammunition in petty quarrels ... the Court must balance even the policy in favor of freedom of speech against the right of the state to protect itself from mobs, riots in the streets, pornography, espionage, and revolution." 168

165 See, e.g., Tushnet, supra note 26 , at 17 ("I find it difficult to identify a pathology that would lead to the overestimation of risks or underestimation of benefits associated with the dissemination of [animal abuse] videos."); Schauer, Harm(s) and the First Amendment, supra note 26 , at 95 ("[N] one of these cases represents the kind of largely baseless overreaction to trivial or imagined harms that is a significant strand in the history of the First Amendment[.]").

166 Eugene V. Rostow, The Democratic Character of Judicial Review, 66 HARV. L. Rev. 193, 208 (1952) (invoking "the immensely constructive influence of the series of decisions in which the Court is slowly asserting the right of Negroes to vote and to travel, live, and have a professional education without segregation[,] . . . leading public opinion and encouraging public action").

$167 I d$. at 223, commenting on Dennis v. United States, 341 U.S. 494 (1951).

168 Id. at 213. 
A generation later, Professor Vincent Blasi reflected insightfully on the work of the Warren and Burger Courts and upped the ante from classroom to pulpit:

$[\mathrm{O}]$ ne of the most important ways in which adjudication in ordinary times might influence the course of pathology would be by helping to promote an attitude of respect, devotion, perhaps even reverence, regarding... central norms [of free expression].... [T] he bench can serve as a pulpit, and in the past the constitutional commandment to tolerate threatening ideas has been preached rather effectively by such eloquent ministers as Holmes, Brandeis, Roberts, Black, and Stewart. ${ }^{169}$

In its cases moving "content neutrality" to the center of First Amendment doctrine, the Court, in the ensuing decades, has increasingly inclined toward Professor Blasi's advice. As an educator myself, and the husband of a rabbi, it is my observation that we structure our lives as much by the stories we tell as by the analytical constructs we deploy. ${ }^{170}$ And one of the strengths of the Supreme Court's penchant for deploying a categorical hostility to content based infringements on expressive freedom is its capacity to generate both salutary structures of discourse and powerful stories. ${ }^{17}$

The doctrine of content neutrality has protected pornographers and cranks, liars and corporate flacks, obnoxious evangelists and violent video games with fine impartiality. And, in my view, not coincidentally, in the face of both actual attack on the "homeland" on 9/11 and advertent fear mongering for a decade afterward, the public opinion of the nation has remained more resiliently supportive of free expression than it was at the time Dean Rostow penned his admonition, much less at the time that his namesake served time for critiquing American involvement in World War I. ${ }^{172}$ 961, 962-65 (1992) (arguing that the Court educates by constructing and seeking to persuade its audience to adopt narratives of national identity). Eisgruber maintains that $\mathrm{Su}$ preme Court opinions are ultimately efficacious only as they socialize the next generation of the legal elite as law students. Id. But, as Rostow argued, the effect of the examples of case resolution generated by doctrine has a separate and more effectively educative impact on the polity. Rostow, supra note 166 and accompanying text.

171 Then-professor, later Dean and President Bollinger has a similar educational intuition. BOLLINGER, supra note 146, at 124-25 ("The extremes tend to attract attention, and that, as any educator or radical knows, can be pedagogically and symbolically advantageous."). 


\section{A. The Importance of Vivid Commitment to Free Expression}

It is a continuing struggle to leave public space for the "thought we hate. ${ }^{" 173}$ In fortifying the forces of tolerance, Supreme Court cases can be as important for what they demonstrate as what they say. The Roberts Court has invoked an unyielding content neutrality doctrine to strike down inhibitions on corporate flackery and political manipulation, on animal abuse, violent video games, dishonorable pretension, and noxious character assassination. There is something here for almost everyone to hate. The message these cases convey to the observing polity is that our Constitution provides substantial room for thoughts that segments, even large segments, of the country regard as hateful. The visible sacrifice of an array of ideological sacred cows on the altar of free speech gives warrant that the message is more than cheap talk. The message has not gone unnoticed.

Take the treatment of Islam in the American public sphere. After arguing Snyder v. Phelps in the Supreme Court, Margie Phelps, a leading member of the self-consciously abrasive Westboro Baptist Church, confronted a question from hostile reporters as to how she stood on the rights of Muslims to build the so-called "ground zero mosque"which was neither a mosque nor located at Ground Zero. Phelps' response illustrates the power of commitments to generality and reciprocity: "Why ... would anybody be so un-American as to suggest that Muslim Americans cannot worship their God according to their conscience[?] Now it's a false religion, no question about that, but they don't have to agree with me on that." ${ }^{, 74}$

Phelps was hardly unique. There was consensus, even among most opponents of the non-Ground Zero non-mosque that efforts to suppress its establishment by force of law lay beyond the pale. ${ }^{175}$ And

173 The Justices were recently unanimous in professing allegiance to "this Court's tradition of protect[ing] the freedom to express the thought that we hate." Christian Legal Soc'y Chapter of the Univ. of Cal. v. Martinez, 130 S. Ct. 2971, 2994 n.26 (2010) (Ginsburg, J., joined by Stevens, Kennedy, Breyer, and Sotomayor, JJ.); id. at 3000 (Alito, J., dissenting, joined by Roberts, C.J., Scalia \& Thomas, JJ.) ("The proudest boast of our free speech jurisprudence is that we protect the freedom to express 'the thought that we hate." (quoting United States v. Schwimmer, 279 U.S. 644, 654-55 (1929) (Holmes, J., dissenting))).

174 Ryan J. Reilly, TPM Muckraker, Westboro Baptist Church Lawyer: Opposing Cordoba House Is 'Un-American,' TALKING POINTS MEMO (Oct. 8, 2010, 1:35 PM), http://tpmmuckraker.talkingpointsmemo.com/2010/10/westboro_baptists_ground _zero_mosque_opponents_are_un-american.php.

175 Mosque of Misunderstanding, WALL ST. J. (Aug. 15, 2010, 12:01 AM), http://online.wsj.com /article/SB10001424052748704901104575423243201956002.html ("The government has no right to stop imam Feisal Abdul Rauf from developing the abandoned Burlington Coat Factory at 51 Park Place... . Even opponents of the mosque concede this point."); Press Release, Anti-Defamation League, Statement on Islamic Community Center Near 
advocates for tolerance, from Mayor Michael Bloomberg to President Barack Obama, were able to draw on a reservoir of established commitments to reciprocity in support of their positions. ${ }^{176}$

Consensus established, as well, that demonstrations opposing Cordoba House were legally protected, notwithstanding their quota of bile and vituperation. And by similar consensus, subsequent efforts to burn a Koran in Florida were immune to legal prohibition notwithstanding threatened violence overseas. ${ }^{177}$ I confess to feeling satisfaction that the Dove Church backed down on their Koranic auto de fe without legal intervention; the mobilization of public opinion was more salutary than a prosecution would have been. And as one of my students has argued, aggressive official communicative responses to offensive anti-Muslim advertisements in public transit systems are more effective in allowing Muslims to feel supported than the efforts to suppress advertisements that were ultimately blocked as unconstitutional. ${ }^{178}$

Two years after the Cordoba House imbroglio, controversy over the fraudulent and offensive "Innocence of Muslims" video again highlighted American commitment to categorical free speech protection. The repellent video clip denigrating Islam and the Prophet Muhammad—originally screened without incident in July 2012-was uploaded to YouTube with Arabic subtitles on September 4, 2012. ${ }^{179}$ Although domestic offense at the American government's inaction was inaudible, reaction overseas provided occasion for violence. ${ }^{180}$ United States officials tried to persuade Google to block the video. ${ }^{181}$

Ground Zero (July 28, 2010), available at http://www.adl.org/press-center/pressreleases/civil-rights/statement-on-islamic.html ("every right to build at this site").

176 Michael Barbaro, Mayor's Stance on Muslim Center Has Deep Roots, N.Y. Times (Aug. 12, 2010), http://www.nytimes.com/2010/08/13/nyregion/13bloomberg.html?_r=1\&scp= $1 \&$ sq=bloomberg\%E2\%80\%99s\%20fierce\%20defense\&st=cse; Michael R. Bloomberg, Defending Religious Tolerance: Remarks on the Mosque Near Ground Zero, HUFFINGTON POST (Aug. 3, 2010, 4:11 PM), http://www.huffingtonpost.com/michael-bloomberg/mayorbloomberg-on-the-ne_b_669338.html.

177 Suzan Clarke \& Karen Leo, Bloomberg: New York City Islamic Center and Mosque 'Not a Campaign Issue,' ABC News (Sept. 8, 2010), http://abcnews.go.com/GMA/bloombergbuilders-islamic-center-mosque-ground/story? $i d=11580103$ (Bloomberg condemning Koran burning, but asserting legal protection).

178 Engy Abdelkader, 'Savagery' in the Subways: Anti-Muslim Ads, the First Amendment, and the Efficacy of Counterspeech (2013), available at $\mathrm{http}: / /$ ssrn.com/abstract=2264791.

179 The Anti-Islam-Film Riots: A Timeline, THE WeEK (Sept. 18, 2012), http://theweek.com/article/index/233454/the-anti-islam-film-riots-a-timeline.

180 See Lisa Waananen \& Derek Watkins, Spread of Protests Sparked by Anti-Muslim Video, N.Y. Times (Sept. 17, 2012), http://www.nytimes.com/interactive/2012/09/13/ world/middleeast/spread-of-protests-sparked-by-anti-muslim-video.html.

181 E.g., Claire Cain Miller, Google Has No Plans to Rethink Video Status, N.Y. Times (Sept. 14, 2012), http://www.nytimes.com/2012/09/15/world/middleeast/google-wont-rethink- 
But the federal government attempted no legal action against Google, and the video remains available in the face of international pressure. ${ }^{18}$

Violence subsided. ${ }^{183}$ The ultimate position of the United States Government was voiced by President Obama before the United Nations on September 25, 2012. After condemning the video as "crude and disgusting", he continued,

Our Constitution protects the right to practice free speech. Here in the United States, countless publications provoke offense. Like me, the majority of Americans are Christian, and yet we do not ban blasphemy against our most sacred beliefs. As President of our country and Commander-in-Chief of our military, I accept that people are going to call me awful things every day-(laughter)—and I will always defend their right to do so. (Applause.)

Americans have fought and died around the globe to protect the right of all people to express their views, even views that we profoundly disagree with. We do not do so because we support hateful speech, but because our founders understood that without such protections, the capacity of each individual to express their own views and practice their own faith may be threatened. We do so because in a diverse society, efforts to restrict speech can quickly become a tool to silence critics and oppress minorities.

We do so because given the power of faith in our lives, and the passion that religious differences can inflame, the strongest weapon against hateful speech is not repression; it is more speech-the voices of tolerance that rally against bigotry and blasphemy, and lift up the values of understanding and mutual respect. ${ }^{184}$

This is hardly an incident without shadows; injury and death followed protests against "Innocence of Muslims" around the world.

anti-islam-videos-status.html (reporting refusal of Google to block the video despite the request of the White House).

182 This article will not link to the current URL, though it has the First Amendment right to do so.

183 See Mark Lynch, The Failure of \#Muslimrage, FOREIGN POLICY (Sept. 21, 2012), http://lynch.foreignpolicy.com/posts/2012/09/21/a_funny_thing_happened_on_the_w ay_to_muslimrage. See generally Stuart Vincent Campbell, Brazil, Blasphemy, and Free Speech: Why the United States Must Maintain Strong Freedom of Expression Protections in Spite of International Pressure to Punish Anti-Religious Hate Speech (U Minn. - Twin Cities - Sch. L. Working Paper Series, Dec. 15, 2012), available at http://papers.ssrn.com/ sol3/papers.cfm? abstract_id=2211793. But cf. Yasmine Saleh, Egyptian Christians Sentenced to Death for Islam Film, ReUTERS (Nov. 28, 2012, 8:16 AM), http://www.reuters.com/article/2012/11/28/us-egypt-christians-courtidUSBRE8AR0J320121128 (reporting the death sentence imposed in absentia against the film's makers).

184 Barack Obama, U.S. President, Remarks Before the United Nations General Assembly (Sept. 25, 2012), available at http://www.whitehouse.gov/the-pressoffice/2012/09/25/remarks-president-un-general-assembly. 
Psyches and religious commitments were deeply wounded. But the American application of principle erected another signpost to tolerance, and international relations were not ruptured. I cringe to imagine the choices confronting the President if he had been required to rely in defending the United States on the proposition that America protects speech unless its suppression is "disproportionate" to an important interest, or a doctrine that permitted national leaders to override free speech where local officials cannot.

Nor is categorical tolerance an artifact of the relative national calm and national safety of the Obama presidency. Even in the white heat following $9 / 11$, official and unofficial efforts to suppress criticism by force of law were at worst feeble shadows of the attacks directed against critics of World War I, World War II, or the Vietnam War. ${ }^{185}$ I cannot prove it, but it seems to me that the Court's unpalatable judgments in free expression are part of a virtuous cycle. It might have been believed that the public and regular repudiation of cost-justified repression of speech would generate a spreading demand to reject the Court's regime and establish censorship. But, in fact, members of the public, like members of the Court, seem to prefer preserving the rights of their favorite speakers, along with their own self images as not fearing freedom, to establishing the rights of their representatives to suppress their opponents.

\section{B. The Public Meaning of Toleration in a Diverse Democracy and the Demand for Censorship}

The "Innocence of Muslims" conflict highlights a second aspect of a public commitment to content neutrality: a strong and categorical

185 In the aftermath of September 11, Attorney General Ashcroft suggested to Congress that critics who challenged federal efforts to disrupt terrorist operations flirted with treason:

"To ... those who scare peace-loving people with phantoms of lost liberty; my message is this: Your tactics only aid terrorists - for they erode our national unity and diminish our resolve. They give ammunition to America's enemies, and pause to America's friends." Dep't of Justice Oversight, Preserving Our Freedom While Defending Against Terrorism: Hearing Before the S. Jud. Comm., 107th Cong. 313 (2001).

But the suggestion never gained traction. While American citizens condemning the "Global War on Terror" were subjected to surveillance, they lived their lives and voiced their protests largely unmolested, and certainly untroubled by the draconian measures directed against opponents of prior wars. For accounts of these earlier tribulations see Geoffrey R. Stone, Perilous Times: Free Speech in Wartime from the Sedition ACT OF 1798 TO THE WAR ON TERRORISM (2004). See id. at 551 ("The federal government has jailed no one for antiwar dissent. This is a far cry from the nation's experience in 1798, the Civil War, World War I, World War II and the Cold War.").

The status of non-citizen critics, unfortunately, is a different matter. 
doctrine, deployed to review all levels of government alters the meaning of toleration and undercuts demands for censorship.

Professor Eugene Volokh has argued that "each success [for censorship] will help validate the pro-restriction forces' positions in the eyes of voters and legislators who are on the fence. Moreover, each success may reinforce the enthusiasm of the supporters of the restrictions. " 186

He is entirely correct. If "falsity," "offense," or "bad tendencies" are a basis for prohibiting speech, or burdening it "proportionately," then citizens are entitled to draw inferences from non-prohibition of any particular set of expressions that any group of citizens regard as false, offensive, or evil. Either the regulator doesn't care, or she regards the speech as neither false, offensive, nor evil. Failure to regulate becomes tantamount to endorsement. Refusing to prohibit speech which demeans or is viewed as disparaging by an element of the population can be legitimately taken as an insult to those citizens. The same is true for foreign constituencies that might be offended.

A doctrinal focus on proportionality or on illegitimate motivation will stoke demand for censorship. Each doctrine demonstrates censorship is potentially permissible. Each legitimates the grievances of those whose sensitivities are not embodied in law, for those who seek censorship will view their proposals as neither disproportionate nor badly motivated. By contrast, a strong content neutrality doctrine that regularly requires both officials and constituents to forbear and tolerate their least favorite expression inhibits the demand for censorship. It reduces the assumption that censorship is the default option, and undercuts the claim that the failure to censor is an endorsement of insult or offense.

There has been a great deal of writing in the last two decades advancing the proposition that First Amendment doctrines stand as improper and internationally anomalous barriers to establishing a tolerance because they interfere with efforts to suppress hate speech, and racial defamation. Emblematically, Professor Jeremy Waldron has recently declaimed,

The [real] question is about the direct targets of the abuse. Can their lives be led, can their children be brought up, can their hopes be maintained and their worst fears dispelled, in a social environment polluted by [hate speech]? ... Will hate speech be tolerated by law in a wellordered society? . . . The point of the visible self-presentation of a well- 
ordered society, then, is not just aesthetic; it is the conveying of an assurance to all citizens that they can count on being treated justly. ${ }^{187}$

But the "visible self-presentation" conveyed in any given circumstance by an official decision to tolerate noxious speech differs depending on background norms in the polity. A visibly robust commitment to content neutrality alters meaning. If governments have visible authority to exercise discretion in disallowing speech, every decision to allow a particular type of utterance is in effect a government endorsement. By contrast, against a background of flamboyantly unfettered access to the public square for noxious expression, the decision not to censor bestows no imprimatur upon hateful speech. It is another instance of a sometimes uncomfortable commitment to equal dignity. No one can legitimately claim that the government endorses the speech it fails to prohibit when the government lacks that option in the first place.

The internationally unique American doctrine protecting offensive speech from government suppression contributes to a working American pluralism. In a country characterized, as America is, by local control and a multiplicity of unevenly distributed ethnicities, faiths, and political commitments, it supports a long-run equilibrium in which suppression of locally unpopular or offensive groups is off the table. Local majorities are not invited to mobilize behind repression, and local minorities cannot legitimately claim to be subordinated by incomplete censorship.

The point is not new. The Court acknowledged it as it framed the foundations of modern free expression doctrine three generations ago by reversing the conviction of Jehovah's Witnesses for vituperation of Catholics:

The essential characteristic of these liberties is, that under their shield many types of life, character, opinion and belief can develop unmolested and unobstructed. Nowhere is this shield more necessary than in our own country for a people composed of many races and of many creeds. ${ }^{188}$

In a society which is home to a rainbow of cultures, religions, and ethnic communities, the deepest commitments of each culture may well profoundly offend some of its neighbors. In general, America solves the problem not by limiting each citizen to behavior inoffensive to any of our fellows, but by permitting expression which mirrors deep commitments held by any of us. At least in the areas of politics, religion, and public culture, government cannot constrain Americans 
to be ladies and gentlemen inoffensive to the standards of our local compatriots on pain of imprisonment.

I do not mean to overplay the claim, but I suspect that one root of difference between the relatively calm response of American Muslims to the provocation of the "Mohammed cartoons" ropean Muslims stems from the fact that in Europe suppression of noxious communications is a viable policy option. The European failure to vindicate expectations that the government would shield religious groups from public defamation constituted an insulting disappointment. The same inaction in America, like the refusals to censor Pamela Geller or Terry Jones could not be legitimately read as an indignity inflicted by American authorities on Muslims-any more than New York's permission to build the Cordoba House could legitimately constitute an "insult" to offended "patriots."

These perceptions underwrote the process of embedding content neutrality in the Constitutional canon. After observing in Cohen $v$. California that "one man's vulgarity is another's lyric," Justice John Marshall Harlan continued,

The constitutional right of free expression is powerful medicine in a society as diverse and populous as ours. It is designed and intended to remove governmental restraints from the arena of public discussion, putting the decision as to what views shall be voiced largely into the hands of each of us, in the hope that use of such freedom will ultimately produce a more capable citizenry and more perfect polity and in the belief that no other approach would comport with the premise of individual dignity and choice upon which our political system rests. ${ }^{190}$

The continued stream of cases involving confrontations between village tyrants and village Hampdens, abetted by the high profile examples of the Court turning back efforts at Congressional censorship inculcates the habit of bearing "one man's vulgarity." It may callous our public sphere, but in a pluralistic society of constant friction, callouses are not necessarily a bad thing. Some coarsening of our sensibilities may in the long run reduce net discomfort more than sporadic public efforts to suppress incivility. The lesson that terrible evil does not follow noxious speech is learned best by experience. And as

Robert A. Kahn, Why do Europeans Ban Hate Speech? A Debate between Karl Loewenstein and Robert Post, 41 Hofstra L. Rev. 545 (2013); Robert A. Kahn, Flemming Rose, The Danish Cartoon Controversy, and the New European Freedom of Speech, 40 CAL. W. INT'L L.J. 253 (2010).

190 Cohen v. California, 403 U.S. 15, 24 (1971). Justice Harlan's unprecedented use of the word "fuck" in the U.S Reports provided concrete and vivid mimesis. 
with officials, the process of cognitive dissonance may strengthen the belief that forbearance is valuable in and of itself. ${ }^{19}$

\section{The Land of the Free and the Home of the Brave}

Justice Harlan's references in Cohen to the "premise of individual dignity and choice upon which our political system rests" and the generation of a "capable citizenry" highlight a final way in which the stream of cases that emerges from a strong content neutrality doctrine influences the "spirit of the People and of the Government." The outcomes of these cases nourish a sense of national character that underpins a willingness in turn to support free speech in matters more central to self government. ${ }^{192}$ The edifice of judicial opinion, precedent, and concrete outcomes erected by content neutrality doctrine stands as both a monument and a signpost to America's national aspirations as the "land of the free and the home of the brave." 193

191 A similar point applies to Dean Post's claim that content neutrality protections should be limited to allow legal enforcement of civility norms. E.g., ROBERT C. POST, DEMOCRACY, EXPERTISE, AND ACADEMIC FREEDOM: A FIRST AMENDMENT JURISPRUdENCE FOR THE MODERN STATE 24 (2012) ("[J] udicially enforced rights so as to incorporate the sociological insight that some such boundary is necessary if a society is to entrench the civility norms necessary for social cohesion and identity.").

Civility norms need not be legally enforced; we do not require criminal or civil punishment to assure the proper use of "please" and "thank you"; we rely on scolding and social pressure. Conversely, "incivility" norms that encourage citizens to pass over insults to their dearly held beliefs and self images are necessary for stable tolerance in a diverse, democratically-governed polity, and they are difficult to inculcate where municipal force stands ready to enforce civility.

192 Cf. BOLLINGER, supra note 146, at 120 ("A central function of free speech ... is to provide a social context in which we collectively speak, in a public and official setting, to an important aspect of what we might think of as the intellectual character of the society."); Vincent Blasi, The Teaching Function of the First Amendment, 87 Colum. L. REv. 387, 396 (1987) (reviewing BOLLINGER, supra note 146 ("[T] he decision to protect free speech to an extraordinary degree represents... an affirmative gesture, a cultural symbol important to our collective identity.")).

193 E.g., Vincent Blasi, Free Speech and Good Character, 46 UCLA L. Rev. 1567, 1571-72 (1999) ("inquisitiveness, independence of judgment, distrust of authority, willingness to take initiative, perseverance, and the courage to confront evil" are encouraged by protections of an "environment, in which dissent is both an option and an inescapable reality"); Vincent Blasi, The First Amendment and the Ideal of Civic Courage: The Brandeis Opinion in Whitney v. California, 29 WM. \& MARY L. REv. 653, 690-92 (1988) (highlighting the generative First Amendment influence of Brandeis's argument that " $\mathrm{t}]$ hose who won our independence by revolution were not cowards" and arguing contemporary First Amendment doctrine arises out of "the ideal of engaged, confident, innovative citizenship"); $c f$. Terminiello v. Chicago, 337 U.S. 1, 4 (1949) ("The right to speak freely ... sets us apart from totalitarian regimes. [Free speech] may indeed best serve its high purpose when it induces a condition of unrest, creates dissatisfaction with conditions as they are, or even stirs people to anger.") 
The argument that constitutional adjudication, national selfdefinition and a political culture of robust free speech reinforce one another recurs regularly in the rhetoric that a phalanx of Justices uses in their opinions. Affirmations of the "profound national commitment to the principle that debate on public issues should be uninhibited, robust, and wide-open," penned by Justice Brennan in New York Times $v$. Sullivan, underwrote the genesis of content neutrality doctrine in Mosley. ${ }^{194}$ They have been echoed by Justices Alito and Roberts, along with Chief Justices Rehnquist and Stevens. ${ }^{195}$

Justice Kennedy, who has played a central role in crafting free speech doctrine for the better part of a generation declaims that "[a]t the heart of the First Amendment lies the principle that each person should decide for himself or herself the ideas and beliefs deserving of expression, consideration, and adherence." 196 He argues that the norm of content neutrality emerges from the aspiration that "free speech, thought, and discourse are to remain a foundation of our freedom." ${ }^{197}$ And he maintains further that "content-based prohibitions" harbor the "constant potential to be a repressive force in the lives and thoughts of a free people."198

194 Police Dep't of City of Chicago v. Mosley, 408 U.S. 92, 96 (1972) (quoting N.Y. Times Co. v. Sullivan, 376 U.S. 254, 270 (1964)) ("Any restriction on expressive activity because of its content would completely undercut the "profound national commitment to the principle that debate on public issues should be uninhibited, robust, and wide-open.'”).

195 Knox v. Serv. Emps. Int'l Union, Local 1000, 132 S. Ct. 2277, 2288 (2012) (Alito, J.); Ariz. Free Enter. Club's Freedom Club PAC v. Bennett, 131 S. Ct. 2806, 2828-29 (2011) (Roberts, C.J.); Snyder v. Phelps, 131 S. Ct. 1207, 1215 (2011) (Roberts, C.J.); Christian Legal Soc'y Chapter of the Univ. of Cal. v. Martinez, 130 S. Ct. 2971, 3020 (2010) (Alito, J., dissenting) ("Even if the United States is the only Nation that shares this commitment to the same extent ...."); FEC v. Wis. Right to Life, Inc., 551 U.S. 449, 467-68 (2007) (Roberts, C.J.); Bartnicki v. Vopper, 532 U.S. 514, 534 (2001) (Stevens, J.); Id. at 554 (Rehnquist, C.J., dissenting); $c f$. City of Houston v. Hill, 482 U.S. 451, 462-63 (1987) (“[F]reedom of individuals verbally to oppose or challenge police action without thereby risking arrest is one of the principal characteristics by which we distinguish a free nation from a police state.") (citation omitted) (quoted in Hill v. Colorado, 530 U.S. 703, 774-75 (2000) (Kennedy, J., dissenting)); N.Y. Times Co. v. Sullivan, 376 U.S. 254, 270 (1964), quoted in Police Dep't of Chi. v. Mosley, 408 U.S. 92, 96 (1972).

196 Turner Broad. Sys., Inc. v. FCC, 512 U. S. 622, 641 (1994), quoted in Agency for Int'l Dev. v. Alliance for Open Soc'y Int'l, Inc., 133 S. Ct. 2321, 2327 (2013).

197 United States v. Alvarez, 132 S. Ct. 2537, 2548 (2012). See id. at 2550 ("Society has the right and civic duty to engage in open, dynamic, rational discourse. These ends are not well served when the government seeks to orchestrate public discussion through contentbased mandates.").

198 Ashcroft v. ACLU, 542 U.S. 656, 660 (2004). See Int'l Soc'y for Krishna Consciousness v. Lee, 505 U.S. 672, 696 (1992) (Kennedy, J., concurring in judgments) ("[I]n a free nation citizens must have the right to gather and speak with other persons in public places. The recognition that certain government-owned property is a public forum provides open notice to citizens that their freedoms may be exercised there without fear of a cen- 
The Supreme Court's doctrinal commitment to content neutrality is unlikely to be a staple of either tweets or water cooler conversation. The words the Court uses in its opinions do not forge constitutional culture. $^{199}$ But the succession of cases in which the Court turns back national as well as local efforts to cabin noxious expression can serve that function. The stories that the Court enacts-along with those that its doctrines impel lower courts to enact in their adjudications and local decision makers to embody in their standard operating procedures-can serve as clear markers of national commitment and identity. ${ }^{200}$ And of course when "ordinary citizens see others like themselves" involved in contentious politics, "demonstrations have a demonstration effect." ${ }^{\text {201 }}$ A populace regularly exposed to vivid ex-

sorial government, adding tangible reinforcement to the idea that we are a free people.”); McCreary Cnty. v. ACLU, 545 U.S. 844, 881-82 (2005) (O'Connor, J., concurring) ("Free people are entitled to free and diverse thoughts, which government ought neither to constrain nor to direct.").

199 In this, my argument differs from that of ROBERT L. TSAI, ElOQUENCE AND REASON: Creating a First Amendment Culture (2008). Professor Tsai insightfully raises the question of how the cluster of rights identified by the First Amendment have become "culturally salient ideas, inscribed in the habits and outlooks of ordinary Americans" as a "badge of citizenship." Id. at ix.

Professor Tsai's answer gives dispositive weight to the rhetoric and metaphors deployed in Supreme Court opinions. Much as I love a good metaphor and enjoy teaching Barnette, the notion that the Supreme Court's rhetorical tropes impact popular constitutional culture seems to me quite a stretch. See, e.g., Gregory A. Caldeira, Courts and Public Opinion, in The American Courts 303 (John B. Gates \& Charles A. Johnson eds., 1990) ("[That more people could identify Judge Wapner than the Chief Justice] illustrates one facet of the Supreme Court's... lack of saliency in all but few situations."); TERRI Jennings Peretti, In Defense of A Political Court 167 (1999) ("Clearly the Supreme Court lacks salience for most Americans.... Supreme Court decisions pass by virtually unnoticed by most Americans[.]").

200 The textbooks that shape the civic understanding of American public school students form and nourish American constitutional culture as well. One recent study found that these textbooks increasingly "construct a popular constitutional culture that is ... broadly protective of unpopular speech" from the material of Supreme Court cases. Tom Donnelly, A Popular Approach to Popular Constitutionalism: The First Amendment, Civic Education, and Constitutional Change, 28 QUINNIPIAC L. REv. 321, 326-27, 333 (2010). In drafting textbooks, as in preaching to citizens, officials and legal elites, vivid applications of unyielding categorical rules of content neutrality are likely to be particularly effective.

201 David S. Meyer \& Sidney Tarrow, A Movement Society: Contentious Politics for a New Century, in The Social Movement Society: Contentious Politics for a New Century 227 (David S. Meyer \& Sidney Tarrow eds., 1998); see, e.g., MAYER N. ZALD \& BERT UsEem, MOVEMENT AND COUNTERMOVEMENT INTERACTION: MOBILIZATION, TACTICS, AND STATE Involvement 247, 247-48 (Mayer N. Zald \& John D. McCarthy, eds. 1987); Marta Tienda, Poor People and Poor Places: Deciphering Neighborhood Effects on Poverty Outcomes, in MACrO-Micro LinKageS IN SOCIOLOGY 244, 247 (Joan Huber ed., 1991); Debra C. Minkoff, The Sequencing of Social Movements, 62 AM. SOC. Rev. 779, 780 (1997); cf. SAMUEL Huntington, The Third Wave: Democratization in the Late Twentieth Century, 33, 101 (1991). 
amples of others practicing free speech as a part of a free people is less likely to be cowed by local or national authority into forfeiting their own rights out of ignorance or timidity.

A generation ago, I was chatting with my late brother-in-law, an Israeli army officer, about my work. I mentioned Texas $v$. Johnson, ${ }^{202}$ and he expressed envy. "What a strong country you have!" he exclaimed. "Our government feels compelled to throw teenagers in jail for showing the Palestinians' flag. Your Supreme Court will protect even people who burn your own." The self understanding of America as a land which protects even flag burners provided an important cultural resource a decade later when higher stakes were on the table in the aftermath of $9 / 11$.

Examples that regularly repopulate the free speech canon under a regime of strong content neutrality can shape both the popular constitutional culture and the culture of government decision makers. A Supreme Court announcement that "[o] ur constitutional tradition stands against the idea that we need Oceania's Ministry of Truth, ${ }^{203}$ backed up by the invalidation of a manifestly appealing statute protecting military honors, provides a constitutional landmark by which lawmakers and public officials may navigate. It gives heft to the repeated advice of lawyers that local lawmakers may neither bar evangelists from the French Lick casino, nor animal advocates from the Red Nose Run, nor Tea Party and Occupy protestors from the village green. And it will strengthen the hand of the legislative aide or Assistant U.S. Attorney who advises her principal that imprisoning critics of the next war is not an option.

Finally, there is the question of the impact of tolerance of repugnant speech on the welfare of society as a whole. Content based statutes are often directed against real or at least plausible harms both to individual interests and to the temper of social life. To those who feel or fear such harms deeply, the admittedly soft claims for "constitutional culture" may be an unpersuasive counterweight. Classical defenses of free speech rest in part on the proposition that the imposition of orthodoxy by force of law is likely to impede the search for the truth necessary to self-governance. Yet it is a stretch to claim that violent video games, dog fight videos, and false claims to military honors are essential or even useful in the search for truth. And I must acknowledge that an emerging strand of behavioral research casts renewed doubt on the proposition that true speech will drive

202 Texas v. Johnson, 491 U.S. 397 (1989).

203 Alvarez, 132 S. Ct. at 2547. 
out false. Exposure to refutations of false statements is often likely to either embed the falsehoods further in the consciousness of listeners, or to provoke defensive attachments to threatened beliefs. ${ }^{204}$

The practical virtues of America's system of free expression lie not only in persuasion of listeners by force of argument but in the capacity of dissents from the status quo to encourage listeners to hew to their own observations in the face of pressures toward falsification. ${ }^{205}$ An enduring line of research finds that while false perceptions can be implanted by apparent consensus in the opinion environment, a single dissenting voice punctures the effect. ${ }^{206}$ Given the possibilities for jurisdictional arbitrage provided by the internet, the prospect of legal sanction will be ineffective in eliminating falsehood or noxious expression entirely for those who seek it out. But sanctions are likely to differentially suppress and marginalize unpopular speech in the public sphere, and it is this speech that is most crucial to puncturing a false consensus.

If the United States ever finds itself on the brink of descent into totalitarian repression by virtue of the promulgation and currency of falsehoods or scurrilous attacks on social groups, perhaps what is required is a coercive hedge around truth and decency. But in those

204 Brendan Nyhan, Why the "Death Panel" Myth Wouldn't Die: Misinformation in the Health Care Reform Debate, 8 FORUM 1, 5 (2010); Stephan Lewandowsky, Misinformation and Its Correction: Continued Influence and Successful Debiasing, 13 Psychol. SCI. Pub. INT. 106 (2012) (reviewing studies); Brendan Nyhan \& Jason Reifler, When Corrections Fail: The Persistence of Political Misperceptions, 32 POL. BEHAV. 303 (2010); Norbert Schwarz et al., Metacognitive Experiences and the Intricacies of Setting People Straight: Implications for Debiasing and Public Information Campaigns, 39 Advances Experimental SOC. PSYCHOL. 127 (2007); John G. Bullock, Partisanship and the Enduring Effects of False Political Information, ANNUAL MeETing PAPer (Midwest Political Sci. Ass'n), 2006 (on file with the Journal); R. Kelly Garrett \& Brian E. Weeks, The Promise and Peril of Real-Time Corrections to Political Misperceptions, available at http://wp.comm.ohio-state.edu/misperceptions/wp-content/uploads/ 2012/07/garrettweeks-promiseperil-cscw-final.pdf.

205 See Timur Kuran, Now Out of Never: The Element of Surprise in the East European Revolution of 1989, 44 WORLD POL. 7 (1991); Susanne Lohmann, The Dynamics of Informational Cascades: The Monday Demonstrations in Leipzig, East Germany, 1989-91, 47 WORLD POL. 42 (1994). For an extended account of this argument, see CASS R. SUNSTEIN, WHY SOCIETIES NEED DiSSENT 96-110 (2003).

206 Solomon E. Asch, Opinions and Social Pressure, 193 SCI. AM. 31, 34-35 (1955); Solomon E. Asch, Studies of Independence and Conformity: I. A Minority of One Against a Unanimous Majority, 70 Psychol. Monographs: Gen. \& Applied 1, 23-24 (1956); Rod Bond \& Peter B. Smith, Culture and Conformity: A Meta-Analysis of Studies Using Asch's (1952b, 1956) Line Judgment Task, 119 PsyCHOL. Bull. 119, 111-37 (1996); William N. Morris \& Robert S. Miller, The Effects of Consensus-Breaking and Consensus-Preempting Partners on Reduction of Conformity, 11 J. EXPERIMENTAL SOC. PSYCHOL. 215 (1975); $c f$. Gregory S. Berns et al., Neurobiological Correlates of Social Conformity and Independence During Mental Rotation, 58 BIOLOGICAL PsYCHIATRY 245 (2005) (finding MRI readings suggesting actual alteration of perceptions). 
circumstances, efforts to assure decency and stability will not lack for advocates. For today, the barbarians are not at the gates, and fear is likely to do more harm than bravery.

\section{CONCLUSION: Two CHEERS FOR CONTENT NEUTRALITY}

The practical case for a central and strong First Amendment doctrine of content neutrality does not rely on claims that the doctrine is entailed by first order constitutional commitments or theories. Three conclusions follow from this posture.

First, "content neutrality" is not the totality of a properly functioning system of protection for free expression. A keystone is not a castle; it is not even an arch. For a doctrine of content neutrality to function effectively, it must be buttressed by doctrines that prevent evasion of its constraints by vague, but content neutral burdens on expression, ${ }^{207}$ and doctrines that preclude the government from vesting content neutral but unbridled discretion in official decision makers. ${ }^{208}$

Likewise, a full system of First Amendment protection cannot abandon doctrines that empower courts in appropriate cases to invalidate content neutral restrictions that effectively suppress expression without adequate justification. Justice Breyer's call for proportionality is well rooted in a line of cases reviewing incursions on free speech for overbreadth. ${ }^{209}$ Even content neutral laws cannot be permitted to foreclose an entire medium of expression. ${ }^{210}$ The Court, in word, and case law elaboration from the lower courts in deed, has appropriately directed inquiry of some rigor into particular limitations that threaten to unduly burden free expression, regardless of motivation or content neutrality. ${ }^{211}$

207 E.g., FCC v. Fox Television Stations, Inc., 132 S. Ct. 2307, 2318 (2012); Reno v. ACLU, 521 U.S. 844, 870-71 (1997); Baggett v. Bullitt, 377 U.S. 360, 372 (1964); see, e.g., Citizens United v. FEC, 130 S. Ct. 876, 889 (2010).

208 E.g. Forsyth Cnty. v. Nationalist Movement, 505 U.S. 123, 133 (1992); Lakewood v. Plain Dealer Publ'g. Co., 486 U.S. 750, 757 (1988); see Thomas v. Chi. Park Dist., 534 U.S. 316, 323 (2002).

209 E.g. Houston v. Hill, 482 U.S. 451, 458-59 (1987).

210 City of Ladue v. Gilleo, 512 U.S. 43, 55 (1994) (residential lawn and window signs); Schad v. Borough of Mount Ephraim, 452 U.S. 61, 75-76 (1981) (live adult entertainment); Jamison v. Texas, 318 U.S. 413, 416 (1943) (handbills); Martin v. City of Struthers, 319 U.S. 141, 145-49 (1943) (door-to-door distribution of literature); Schneider v. State, 308 U.S. 147, 164-65 (1939) (pamphlets); Lovell v. City of Griffin, 303 U.S. 444, 451-52 (1938) (pamphlets).

211 See supra note 73 and accompanying text. 
Second, the arguments for content neutrality are strongest where the danger of excessive fear and censorial zeal is greatest. This aspect might suggest that the strong form of content neutrality should be limited to its heartland of policing the exercise of authority by village tyrants over public forums, leaving more responsible legislators to directly regulate communications in the public interest with only constraint of showing a public regarding justification or motivation. Or that strong content neutrality should be abandoned in areas where social concern is great and the value of speech is low. ${ }^{212}$ Courts have been tempted to trim the doctrine with clever definitional dodges, or pare it back with exceptions as a way of escaping uncomfortable outcomes. Thus, in City of Renton v. Playtime Theaters Inc. ${ }^{213}$ and its sequellae, the Court insisted on characterizing limits on sexualized entertainment venues as "content neutral." Holder v. Humanitarian Law Project $^{14}$ treated the prohibition on teaching humanitarian law as a crucial prop of the Global War on Terrorism exempt from the normal constraints of First Amendment protections.

The Court will be able to get away with a few of these moves. But the content neutrality doctrine is effective in molding the "spirit of the government and of the people" only if it is more than cheap talk. It is crucial that that the doctrine in fact generates outcomes that sacrifice a variety of social interests that are cost-justified in the short run. If every time a first order public benefit appears to justify prohibition the law is labeled "content neutral", the trick won't work. This is why the flag burning cases during the 1990s, like the recent spate of "counterintuitive" protections is important. And that is why the assurance in Humanitarian Law Project of the limits of its exceptional deference to foreign policy determinations may preserve the structure if but only if courts are willing to take the alleged limits seriously. $^{215}$

Third, the arguments here are based on behavioral assumptions. And those assumptions may be wrong. Having invoked Justice Robert

212 E.g. Owen M. Fiss, Free Speech and Social Structure, 71 IOwA L. REv. 1405, 1414 (1986) (arguing that focus on street corner speech is not the proper frame for other free speech doctrines); Cass R. Sunstein, Low Value Speech Revisited, 83 NW. U. L REv. 555, 560 (1989); Cass R. Sunstein, Pornography and the First Amendment, 1986 DukE L.J. 589, 603-04 (1986) (suggesting factors by which the courts should evaluate the value of types of speech). 475 U.S. $41,47-48$ (1986). 130 S. Ct. 2705,2720 (2010).

215 E.g. Al Haramain Islamic Found., Inc. v. U.S. Dep't of Treasury, 686 F.3d 965, 998 (9th Cir. 2012) (upholding the right of the Multicultural Association of Southern Oregon to "speak[] to the press, hold[] demonstrations, and contact[] the government" in coordination with a "designated" terrorist entity, relying on Holder's limits). 
Jackson's rhetorical borrowing from Thomas Gray and his praise of generality, it seems only sporting to acknowledge that Justice Jackson expressed concern that if local decision makers were not empowered to exercise discretion in controlling speech, a shell-shocked populace would abandon civil liberties in the wake of the ensuing anarchy. ${ }^{216}$ As the Court began to forge a doctrine of content neutrality, Justice Jackson worried,

Compelling a choice between allowing all meetings or no meetings is a dubious service to civil liberties... Perhaps it is the fever of our times that inclines the Court today to favor chaos. My hope is that few will take advantage of the license granted by today's decision. But life teaches one to distinguish between hope and faith. ${ }^{217}$

Six decades of experience suggests that faith in a people and a government guided by maxims of content neutrality is far better founded than Justice Jackson might have guessed.

216 Terminiello v. Chicago, 337 U.S. 1, 36-37 (1949) (Jackson, J., dissenting) (“[I]f we maintain a general policy of free speaking, we must recognize that its inevitable consequence will be sporadic local outbreaks of violence, for it is the nature of men to be intolerant of attacks upon institutions, personalities and ideas for which they really care. In the long run, maintenance of free speech will be more endangered if the population can have no protection from the abuses which lead to violence.").

217 Kunz v. New York, 340 U.S. 290, 307, 314 (1951) (Jackson, J., dissenting). 


\section{APPENDIX I: ROBERTS COURT OPINIONS REFERRING TO CONTENT NEUTRALITY DOCTRINE}

\section{A. Content Based Regulation}

\section{Regulation invalidated}

(1) Agency for Int'l Dev. v. Alliance for Open Soc'y Int'l, Inc., 133 S. Ct. $2321(2013)$

(2) United States v. Alvarez, 132 S. Ct. 2537 (2012)

(3) FCC v. Fox TV Stations, Inc., 132 S. Ct. 2307 (2012) resolving question avoided in FCC v. Fox TV Stations, Inc., 556 U.S. 502 (2009)

(4) Lefemine v. Wideman, 133 S. Ct. 9 (2012)

(5) Ariz. Free Enter. Club's Freedom Club PAC v. Bennett, 131 S. Ct. 2806 (2011)

(6) Brown v. Entm't Merchs. Ass'n, 131 S. Ct. 2729 (2011)

(7) Sorrell v. IMS Health Inc., 131 S. Ct. 2653 (2011)

(8) Snyder v. Phelps, 131 S. Ct. 1207 (2011)

(9) United States v. Stevens, 130 S. Ct. 1577 (2010)

(10) Citizens United v. FEC, 558 U.S. 310 (2010)

\section{Regulation upheld}

(1) Nev. Comm'n on Ethics v. Carrigan, 131 S. Ct. 2343 (2011)

(2) Holder v. Humanitarian Law Project, 130 S. Ct. 2705 (2010)

(3) Milavetz, Gallop \& Milavetz, P.A. v. United States, 130 S. Ct. 1324 (2010)

(4) Pleasant Grove City v. Summum, 555 U.S. 460 (2009)

(5) Ysursa v. Pocatello Educ. Ass'n, 555 U.S. 353 (2009)

(6) United States v. Williams, 553 U.S. 285 (2008)

(7) Morse v. Frederick, 551 U.S. 393 (2007)

(8) Tenn. Secondary Sch. Ath. Ass'n v. Brentwood Acad., 551 U.S. 291 (2007)

(9) Davenport v. Wash. Educ. Ass'n, 551 U.S. 177 (2007)

\section{B. Content Neutral Regulation}

\section{Regulation Invalidated}

(1) Randall v. Sorrell, 548 U.S. 230 (2006)

\section{Regulation Upheld}

(1) Christian Legal Soc'y Chapter of the Univ. of Cal. v. Martinez, $130 \mathrm{~S}$. Ct. 2971 (2010) 
(2) Golan v. Holder, 132 S. Ct. 873(2012)

\section{APPENDIX II: ROBERTS COURT FIRST AMENDMENT CASES NOT REFERRING TO CONTENT NEUTRALITY}

\section{A. Content Based}

\section{Regulation Invalidated}

(1) Am. Tradition P'ship v. Bullock, 132 S. Ct. 2490 (2012)

(2) FEC v. Wis. Right to Life, Inc., 551 U.S. 449 (2007) [Wis. Right to Life, Inc. v. FEC, 546 U.S. 410 (2006) ].

\section{Regulation Upheld}

(1) Reichle v. Howards, 132 S. Ct. 2088 (2012)

(2) Borough of Duryea v. Guarnieri, 131 S. Ct. 2488 (2011)

(3) Beard v. Banks, 548 U.S. 521 (2006)

(4) Garcetti v. Ceballos, 547 U.S. 410 (2006)

(5) Hartman v. Moore, 547 U.S. 250 (2006)

(6) Rumsfeld v. Forum for Academic \& Institutional Rights, Inc., 547 U.S. 47 (2006)

\section{B. Content Neutral}

\section{Regulation Invalidated}

(1) Knox v. SEIU, Local 1000, 132 S. Ct. 2277 (2012)

(2) Davis v. FEC, 554 U.S. 724 (2008)

\section{Regulation Upheld}

(1) Doe v. Reed, 130 S. Ct. 2811(2010)

(2) Locke v. Karass, 555 U.S. 207 (2009)

(3) Crawford v. Marion Cnty. Election Bd., 553 U.S. 181 (2008)

(4) Wash. State Grange v. Wash. State Republican Party, 552 U.S. 442 (2008)

(5) N.Y. State Bd. of Elections v. Lopez Torres, 552 U.S. 196 (2008)

\section{APPENDIX III: METHODOLOGY}

A. Baseline: September 2009-August 2010

In September of 2010, working with a research assistant, I examined a one in five sample of the results of a LEXIS search designed to explore the universe of first amendment cases in the lower federal 
courts. I excluded pro se cases, in which plaintiffs are almost invariably unsuccessful, and which almost invariably generate opinions which provide no guidance to attorneys, citizens, and officials.

The search in the LEXIS Federal Courts data base was:

date > August 2009 and date < September 2010 and first amendment and speech or expression and not (counsel (pro se))

Of the seventy-two court of appeals cases in the sample, fifty-seven $(79 \%)$ actually raised First Amendment free expression issues. Of 220 district court cases, 179, (80\%) actually raised First Amendment free expression issues.

Among the fifty-seven court of appeals First Amendment cases, twenty-one $(36 \%)$ involved employees claiming retaliation, and among the 179 district court First Amendment cases, sixty-eight $(37 \%)$ involved employee retaliation. Employee retaliation cases are governed by a distinct set of First Amendment doctrines in which the content neutrality of the government action is not at issue.

B. Total Universe of First Amendment Cases: September 2009-August 2013

On December 18, 2013 a search of the LEXIS Federal Courts data base for the four year period September 2009 through August 2013 generated 1310 court of appeals cases and 4931 district court cases.

The search was:

date > August 2009 and date < September 2013 and first amendment and speech or expression and not (counsel (pro se)

Applying the baseline result that roughly $80 \%$ of these results actually raised First Amendment free expression issues yields an estimate that 1048 reported court of appeals cases and 3945 reported district court cases addressed First Amendment free expression issues during the period.

Applying the baseline result that roughly $36 \%$ of the First Amendment free expression cases involved public employees, yields an estimate of 670 non-employee cases in the courts of appeals and 2524 in the district courts.

\section{Content Neutrality Cases September 2009-August 2013}

On December 18, 2013, a search of the LEXIS Federal Courts database for the same period to identify cases that used "content neutrality" or cognate phrases yielded 291 court of appeals cases and 598 district court cases

The search was:

date $>$ August 2009 and date $<$ September 2013 and content based or content neutral or viewpoint based or viewpoint neutral or view- 
point discrim! or content discrim! and first amendment and speech or expression and not (counsel (pro se)

I examined the sample and eliminated cases which did not actually deal with First Amendment free expression issues. I also culled duplicate cases. For each level [court of appeals and district] I retained the latest case in a series of duplicates. The same case could appear, however, in both Appeals and District samples. After culling, the Appeals sample contained 233 cases, and the District sample contained 480 cases.

At the Appeals level, five of the remaining cases involved government employees. At the District level, twenty-one of the remaining cases involved government employees.

D. Proportion of Content Neutrality Cases September 2009-February 2013

\begin{tabular}{|l|c|c|c|}
\hline & $\begin{array}{c}\text { “FIRST } \\
\text { AMENDMENT" }\end{array}$ & $\begin{array}{c}\text { “CONTENT } \\
\text { /VIEWPOINT" }\end{array}$ & PROPORTION \\
\hline \hline $\begin{array}{l}\text { COURT OF } \\
\text { APPEALS }\end{array}$ & 1310 & 291 & 0.22 \\
\hline \hline $\begin{array}{l}\text { AFTER } \\
\text { CULLING }\end{array}$ & 1048 & 233 & 0.22 \\
\hline \hline $\begin{array}{l}\text { NON } \\
\text { EMPLOYEE }\end{array}$ & 670 & 228 & 0.34 \\
\hline \hline $\begin{array}{l}\text { DISTRICT } \\
\text { COURT }\end{array}$ & 4931 & 598 & 0.12 \\
\hline \hline $\begin{array}{l}\text { AFTER } \\
\text { CULLING }\end{array}$ & 3945 & 480 & 0.12 \\
\hline \hline $\begin{array}{l}\text { NON } \\
\text { EMPLOYEE }\end{array}$ & 2524 & 459 & 0.18 \\
\hline
\end{tabular}

E. Coding

\section{Claimants/Government}

The party invoking First Amendment free expression rights, whether postured as defendant or plaintiff, was designated the 
"claimant." The source of the regulation or action challenged by the claimant was designated the "government".

\section{a. Government}

- "Government" actors were coded "US," "State," or "Village."

- "US" actors included both federal regulatory agencies of broad jurisdiction and the federal legislature.

- "State" actors included both state regulatory agencies of broad jurisdiction and the state legislature.

- "Village" actors included municipal executives and executive agents, municipal regulatory agencies, and municipal legislative bodies. Because the decision making process and incentives of street level bureaucrats and limited purpose agencies like state universities are similar to those of their municipal counterparts, such decision-makers were included as "village" actors regardless of the government that employed them.

\section{b. Claimants}

Claimants were coded in constellations of cultural and political affiliation.

- "Business" claimants were generally not disaggregated by product service or size.

- "Adult Businesses," which provide sexualized goods or services, and are subject to distinctive First Amendment doctrines were coded separately, as were "Media" claimants for the same reason.

- "Union" claimants and "Nonprofit Claimants" were coded separately.

- "Right Wing" claimants included conservative secular activists ranging from conservative college enthusiasts to gun rights and property rights groups to Tea Party activists.

- "Christian" claimants included Christian activists seeking to evangelize, or to oppose gay rights or abortion or "creeping Islamism." "NonChristian religious" claimants were coded separately.

- "Left Wing" claimants included antiwar activists, animal rights activists, immigrant rights activists, environmental activists, civil rights protestors, gay rights activists, abortion rights activists, "Occupy" groups, and anticapitalist activists.

- "Individuals" included otherwise unaffiliated individual claimants: students, idiosyncratic local curmudgeons and gadflies, artists, property owners, public employees, accused sex offenders, accused spies, flamboyant and pathological liars, prisoners, and psychics.

\section{Win/Loss}

When a claimant asserting First Amendment claims prevailed on any issue in a case, the case was coded a "win", whether the decision was final or interlocutory. The rationale here is that in looking for 
guidance, both future claimants and governments will treat interlocutory determinations as indicative of viable claims

This coding may inflate the ultimate success rates of claimants where an interlocutory determination is reversed either on appeal or by future final determinations. The latter inflation is reduced but not eliminated because only the latest observation in the four year series is coded.

The coding also does not disaggregate issues present in a single case. The rationale here is that in many cases, plaintiffs invoke a variety of theories to challenge a government action and may obtain relief if they prevail on any of them. Again, in some cases, this characterization may inflate success rates; where a plaintiff challenges a package of government actions (for example an array of regulations interfering with demonstrations) and prevails against only one of the package, the case is coded as a win. Life is short.

\section{Case Types}

"Case Type" coding refers to the predominant set of First Amendment issues in the case.

Most of the codings are obvious and distinctive.

- Campaign Regulation

- Commercial Speech

- Public Employees

- Government Speech/Unconstitutional Conditions (cases in which official entities claimed the benefit of first amendment doctrines distinctively allowing the government to promulgate its own message with its own funds or resources)

- Limited Public Forum (Cases within this group were also coded to recognize the recurring instances of individuals who claimed the right to speak at public meetings.)

- Public Forum

- School

- Telecom

- Direct Regulation (cases in which the challenged regulation was a direct prohibition or regulation of activities that claimed first amendment protection. The group includes noise regulations, regulations of "adult" businesses, prohibitions or sanctions against particular types of speech on the theory that they are unprotected.) These cases were also coded to recognize the recurring and large set of cases involving regulations of billboard regulations.

- Other includes cases distinctively invoking a right to petition, a right to pray, generic concerns with retaliation for First Amendment activities, and the rights of nonprofit corporations to association or freedom from regulation. 


\section{Counsel}

Almost a third of case reports in the sample disclosed that the claimants were represented by repeat-playing ideologically oriented counsel, often from "public interest" organizations of the left or right. Case reports which did not disclose such representation were coded "uncounseled". This may under represent the role of repeat playing counsel, since official reports may not fully identify such counsel.

Where repeat playing counsel was disclosed, coding grouped counsel by cultural and political affiliation. The Alliance Defense Fund, the Right to Life Defense Fund, the Institute for Justice, the Christian Law Association, Liberty Counsel, Liberty Institute, the Pacific Justice Institute, and similar groups were coded as "Right Counsel."

The ACLU, the Electronic Frontier Foundation, the Brennan Center, the Center for Constitutional Rights, and similar groups were coded as "Left Counsel." 
